\title{
CIDADE E HABITAÇÃO
}

TENDÊNCIAS URBANAS CONTEMPORÂNEAS Registro do Seminário Internacional em Cidade e Habitação - Junho de 2018 Coordenação Geral Acadêmica: Eliete de Pinho Araujo

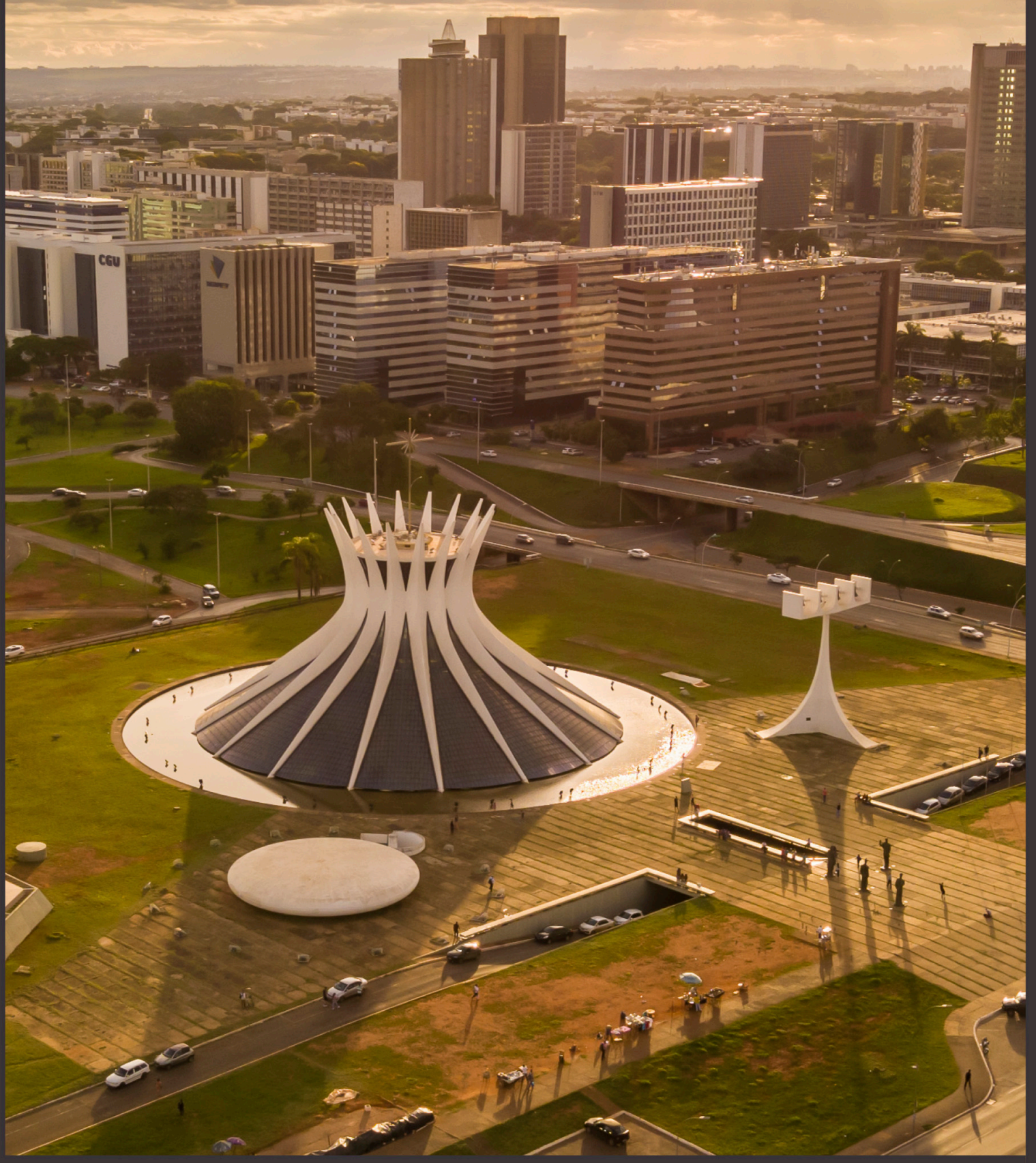




\section{Tendências urbanascontemporâneas}

Registro do Seminário Internacional em Cidade e Habitação promovido pelo Curso de Mestrado em Arquitetura e Urbanismo em junho de 2018

Coordenação geral acadêmica:

Professora Dra. Eliete de Pinho Araujo

Brasília

2018 
CENTRO UNIVERSITÁRIO DE BRASÍLIA - UniCEUB

Reitor

Getúlio Américo Moreira Lopes

INSTITUTO CEUB DE PESQUISA E DESENVOLVIMENTO - ICPD

Diretor

João Herculino de Souza Lopes Filho

Diretor Técnico

Rafael Aragão Souza Lopes

Comissão organizadora:

Coordenação geral acadêmica: Professora Dra. Eliete de Pinho Araujo

Coordenação acadêmica: Gustavo Alexandre Cardoso Cantuária Maria Eleusa Montenegro

Comissão técnico-científica: Ana Paula Borba Gonçalves Barros Gustavo Alexandre Cardoso Cantuária

Maria Eleusa Montenegro

Rossana Maria Delpino Sapena

Sávio Tadeu Guimarães

Disponível em: http://www.repositorio.uniceub.br/jspui/handle/235/12751

Dados Internacionais de Catalogação na Publicação (CIP)

Cidade e habitação: tendências urbanas contemporâneas / organizadora, Eliete de Pinho Araujo et al. - Brasília: UniCEUB: ICPD, 2018. $159 \mathrm{p}$.

ISBN 978-85-61990-91-6

1.Arquitetura e Urbanismo. I. Centro Universitário de Brasília. II. Título.

CDU 711.4

Ficha catalográfica elaborada pela Biblioteca Reitor João Herculino 


\section{SUMÁRIO}

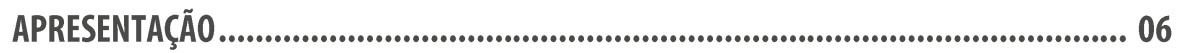

PALESTRAS DOS CONVIDADOS

TENDÊNCIAS RECENTES DAS DINÂMICAS URBANASE

RESIDENCIAIS

09

MANUEL GARCIA DOCAMPO

SALUD PÚBLICA Y PLANIFICACIÓN DEL ESPACIO:

URBANISMO PARA LA PROMOCIÓN DE LA SALUD .24

MARIA JOSÉ LÓPEZ REY

AS CIDADES VERDES DA GUINÉ-BISSAU

MANUEL DE CARVALHOESOUSA

GESTÃO DE RESÍDUOS DE CONSTRUÇÃO E SUA APLICAÇÃO EM CONCRETO 55

LIA LORENA PIMENTEL

\section{RESUMOS EXPANDIDOS}

A INFLUÊNCIA DO PATRIMÔNIO CULTURAL MUSEALIZADO NA PERCEPÇÃO DAS CIDADES ..80 CELSO FERNANDO BARROSO LIMA ESÁVIO TADEU GUIMARÃES

A RELAÇÃO TEORIA E PRÁTICA EM UM CURSO SUPERIOR: SUBSÍDIOS PARA O GESTOR ..... 87 MARIA ELEUSA MONTENEGRO, ELIETE DE PINHO ARAUJO EALTAIR STEMLERDA VEIGA

ARQUITETURA VERDE: AS PAISAGENS URBANAS NA CIDADE CONTEMPORÂNEA - A BIOMIMÉTICA CONTEMPLANDO EFICIÊNCIA E CONSTRUÇÃO SUSTENTÁVEL 91

ELIETE DE PINHO ARAUJO EMANUEL GARCIA DOCAMPO

AS CALÇADAS DA ESPLANADA DOS MINISTÉRIOS: ASPECTOS HISTÓRICOS, DE PROJETO E SUA CONFORMIDADE COM A LEGISLAÇÃO E NORMATIZAÇÃO VIGENTES. .95

HUGO OLIVEIRA COSTA ENEUSA MARIA BEZERRA MOTA

COMPONENTES DO DÉFICITHABITACIONAL NO DISTRITO

FEDERAL .98

ANA LUIZA NOVAIS DEMELO EFABIANO JOSÉA. SOBREIRA 
CONCURSOS DE HABITAÇÃO SOCIAL EM BRASÍLIA:

ARQUITETURA, QUALIDADE E SUSTENTABILIDADE.

FABIANO JOSÉA. SOBREIRA

(DES) CONTINUIDADES EM BRASÍLIA: ENTRE A PRESERVAÇÃO

DO PATRIMÔNIO MODERNISTA E SUA ADAPTAÇÃO A

VALORES CONTEMPORÂNEOS.

ADRIANA NUNES DE ALENCAR SOUZA, DAYODARA TEIXEIRA REIS, LETICIA PIRES FERREIRA ESÁVIO TADEU GUIMARÃES

EFICIÊNCIA ENERGÉTICA EM EDIFÍCIOS PÚBLICOS: ADOÇÃO DE CRITÉRIOS DE SUSTENTABILIDADE PARA FISCALIZAÇÃO

PÚBLICA.

LETICIA PIRES FERREIRA E GUSTAVO ALEXANDRE CARDOSO CANTUÁRIA

ENSINO DO DESENHO E SISTEMA CONSTRUTIVO DA

HABITAÇÃO POPULAR POR MEIO DE VIDEOAULAS.

RICARDO CESAR MACHADO EELIETE DE PINHO ARAUJO

ENTRE A PRESERVAÇÃO E A INTERVENÇÃO: DISCUTINDO A COMPLEXIDADE E OS DESAFIOS

PARA BRASÍLIA - DF.

DAYODARA TEIXEIRA REIS, ADRIANA NUNES DE ALENCARSOUZA, LETÍCIA PIRES FERREIRA ESÁVIO TADEU GUIMARÃES

EXISTE RELAÇÃO ENTRE A VIOLÊNCIA E O SISTEMA VIÁRIO?

PAULO CESAR GALANTESIQUEIRA EPAULO AFONSO CAVICHIOLI CARMONA

FACHADAS DE VIDRO E O IMPACTO NO MODERNISMO DE

BRASÍLIA

LAURA DE CASTRO OLIVEIRA GUERREIRO, ANDRÉ LUIZ PRIMO BERTOLETTI G GUSTAVO ALEXANDRE

CARDOSOCANTUÁRIA

HABITAÇÃO SOCIAL PÓS ASSISTÊNCIA TÉCNICA NO DISTRITO FEDERAL

ANA LUIZA NOVAIS DEMELO EJOSÉ GALBINSKI

INVISIBILIDADE URBANA A RELAÇÃO ENTRE MORADORES DE

RUA E A CIDADE

PAULO FERNANDO LISBÔA DE VASCONCELOSE PAULO AFONSO CAVICHIOLI CARMONA 
OS DESAFIOS DA MOBILIDADE A PÉ NOS COMÉRCIOS LOCAIS

DO PLANO PILOTO DE BRASÍLIA 135

NATÁLIA COSTA ARAUJO, EVELINE DOS SANTOS GUIMARÃES E ANA PAULA BORBA GONÇALVES BARROS

PAVIMENTO PERMEÁVEL COMO SOLUÇÃO PARA ESCOAMENTO SUPERFICIAL EM ÁREAS URBANAS: ESTUDO DE CASO EM ESTACIONAMENTO NO PLANO

PILOTO DE BRASÍLIA - DF.

LUANA MOREIRA ENEUSA MARIA BEZERRA MOTA

PODER E CINEMA NO ENSINO DE ARQUITETURA

RICARDO CESARMACHADO

UM ESTUDO SOBRE A VIOLÊNCIA: UMA CONTRIBUIÇÃO PARA

A COMUNIDADE ESCOLAR

ALTAIR STEMLER DA VEIGA, MARIA ELEUSA MONTENEGRO EEIETEDE PINHO ARAUJO 


\section{APRESENTAÇÃO}

Brasília completa 30 anos como cidade Patrimônio da Humanidade com a preocupação de preservar a sustentabilidade e o conforto ambiental na área tombada do plano piloto. Com o enfoque na qualidade espacial sob a luz do discurso sustentável, o seminário visou analisar os espaços públicos na cidade e a arquitetura, com enfoque na habitação, com o objetivo de sugerir diretrizes no âmbito do urbanismo sustentável, a requalificação espacial de áreas degradadas e a transformação arquitetônica de tipologias insustentáveis. O seminário buscou examinar o desempenho das estruturas espaciais urbanas, relacionando suas características físicas como as superfícies verticais e horizontais, bem como a morfologia dos cânions urbanos e seus reflexos na formação de ilhas de calor, e os devidos microclimas, na malha urbana. O adensamento construtivo, como nos setores comerciais, bancários, hoteleiros e de autarquias, com o uso intensivo e exagerado de vidros espelhados e reflexivos, tem causado impacto negativo no desempenho espacial urbano nos microclimas. Virando as costas para a arquitetura vanguardista modernista brasileira, projetada em Brasília de forma competente desde o seu nascimento e, por outro lado amplamente atraída pelas caixas de vidro exageradamente espalhadas e repetidas no hemisfério norte, a capital se espelha em tipologias arquitetônicas que chocam de maneira absurda com o clima deste planalto central. Elementos comumente encontrados na nossa arquitetura moderna como plantas livres, ventilação cruzada, varandas, beirais, cobogós, brise soleils e outros elementos sombreadores, são no momento ignorados em troca da atração fatal do uso do espelho como revestimento externo, pintando um cenário propício para incentivar o surgimento das ilhas de calor e a intensa contribuição negativa nos microclimas adjacentes a essas morfologias urbanas e arquitetônicas. O fenômeno da 
ilha de calor se concretiza assim como o vilão comum na busca do conforto ambiental urbano. Esse seminário tem como foco discutir esse impacto das ilhas de calor no cenário urbano atual, juntamente com os desafios da mobilidade e a transformação urbana na busca da requalificação espacial sustentável. O seminário buscou questionar e analisar as consequências dessa nova linguagem arquitetônica, do surgimento de distintas características de cânions urbanos, da criação da ilha de calor e o reflexo nos microclimas e consequentemente a salubridade dos espaços e a qualidade do conforto ambiental dos seus usuários.

Ainda refletir sobre Brasília e outras cidades de outros países em relação às tendências urbanas e residenciais; cidades saudáveis - urbanismo para a promoção da saúde; Brasília, cidade, habitação e patrimônio; gestão de resíduos de construção e sua aplicação em concreto e as cidades verdes da Guiné-Bissau.

O Seminário visou ainda promover a concepção, o projeto e a gestão seguros, eficientes, eficazes e ambientalmente sustentáveis das edificações dos espaços urbanos e a infraestrutura de serviços. É uma reunião dos profissionais de arquitetura e engenharia e áreas afins, de várias localidades nacionais e internacionais, que discutirão perspectivas da arquitetura e urbanismo a luz da sustentabilidade.

O objetivo foi promover a troca de informações e experiências internacionais no campo de projeto, construção, engenharia, comissionamento, manutenção e gestão. Este evento contribuirá e dará oportunidade aos profissionais brasileiros participarem juntamente com os estrangeiros na discussão dos desafios urbanos do século XXI. Alguns temas abordados foram: Transformação Urbana e Requalificação Arquitetônica, Mobilidade, Sustentabilidade Urbana e Qualidade Espacial. 
Espera-se que o participante seja agente transformador da realidade e que possa atuar de forma crítica e reflexiva sobre questões correlatas ao ambiente urbano e da habitação, para tornar os espaços mais humanos e sustentáveis.

Ao longo do congresso houve uma exposição de trabalhos e artigos dos alunos e professores do Mestrado em Arquitetura e Urbanismo do UniCEUB, selecionados pelo Comitê técnico científico, e dos palestrantes convidados.

No segundo e último dia, 07 de junho, foi feita uma visita técnica pela manhã a diversos locais de Brasília, com destaque aos pontos de localização de algumas das principais obras de Athos Bulcão, espalhadas pela cidade. Entre os locais visitados foram: o Brasília Palace, Teatro Nacional, Igreja Nossa Senhora de Fátima, Quadra 308 Sul (famosa por ser a "quadra padrão") e Parque da Cidade. A visita foi acompanhada por 3 guias especializados da Fundação Athos Bulcão.

O seminário ainda terá como resultado a publicação deste Ebook, reunindo as atividades realizadas e a inclusão dos artigos elaborados pelos alunos e professores do programa, além das palestras dos convidados palestrantes.

Palavras-chave: Arquitetura; Desempenho ambiental; Habitação; Saúde; Sustentabilidade. 


\title{
PALESTRAS DOS CONVIDADOS
}

\section{TENDÊNCIAS RECENTES DAS DINÂMICAS URBANAS E RESIDENCIAIS}

\author{
Manuel García Docampo ${ }^{1}$
}

\section{CAMBIOS SOCIALES Y CAMBIOS URBANOS}

\begin{abstract}
Si se va a hacer un nuevo urbanismo, no estará basado en las fantasías gemelas del orden y la omnipotencia; lo que tendrá que presentar será la incertidumbre; ya no estará dedicado a la disposición de objetos más o menos permanentes, sino a la irrigación de los territorios con posibilidades; ya no buscará configuraciones estables, sino la creación de ámbitos susceptibles de acomodar procesos que no admitan la cristalización en formas definitivas. (KOOLHAAS, 1996: 8-9).
\end{abstract}

El urbanismo surge como una herramienta que genera la sociedad para coordinar los diferentes intereses que convergen en la producción y demanda del espacio. Esos intereses han cambiado y evolucionado de la misma manera que lo hecho tanto la ciudad como la sociedad.

Los cambios estructurales inherentes a cada sociedad son denominados en sociología como Cambios Sociales. Éstos, a diferencia de otros acontecimientos cotidianos son, por definición, cambios sistémicos que suelen afectar, en general, aunque con diferentes cronologías, a todas las sociedades. Intentar explicar esas transformaciones ha sido una tarea recurrente de la Sociología ${ }^{2}$. Una de las propuestas más básicas y asumidas es la de Daniel Bell (1973). En su obra El advenimiento de la Sociedad Postindustral expone los tres estadios por los que van

\footnotetext{
${ }^{1}$ manuel.garcia.docampo@udc.es

Universidade da Coruña. Grupo de Estudos Territoriais.

${ }^{2}$ Intentar explicar la evolución de la sociedad a partir de identificar una serie "fases" o "estadios" ha sido una estrategia recurrente en Ciencias Sociales. Se trata de recurso para interpretar los procesos de Cambio Social muy usual desde el inicio de la Sociología como Ciencia. Así, la Ley de los Tres Estadios de Comte (1842), el paso de Comunidad a Sociedad de Tönnies (1887), el Materialismo Histórico de Marx (1848) o la División Social del Trabajo de Durkheim (1893).
} 
pasando todas sociedades: agrario, industrial y postindustrial. Las dos primeras no precisan mucha explicación, la tercera, la postindustrial, era una propuesta innovadora en aquel momento (los setenta del siglo XX). Según él, ya se percibían en la mayor parte de los países de la OCDE una serie de características diferentes a la de períodos anteriores. Entre ellos, los más relevantes eran que se trata de una economía focalizada en conocimientos teóricos y tecnológicos.

Figura 1 - Características de las sociedades según D. Bell

\begin{tabular}{|l|l|l|l|}
\hline Sociedad & Preindustrial & Industrial & Postindustrial \\
\hline $\begin{array}{l}\text { Base } \\
\text { económica }\end{array}$ & Agraria & Industrial & Servicios \\
\hline Clases & Estamentos & $\begin{array}{l}\text { Burguesía y Proletariado en } \\
\text { conflicto }\end{array}$ & $\begin{array}{l}\text { Clases } \\
\text { profesionales } \\
\text { técnicas }\end{array}$ \\
\hline $\begin{array}{l}\text { Principio } \\
\text { axial }\end{array}$ & Orden & Desarrollo económico & $\begin{array}{l}\text { Conocimiento } \\
\text { teórico }\end{array}$ \\
\hline $\begin{array}{l}\text { Orientación } \\
\text { futura }\end{array}$ & Satisfacción necesidades & Incrementar producción & Tecnología \\
\hline $\begin{array}{l}\text { Tomas de } \\
\text { decisión }\end{array}$ & Absolutismo & Democracia liberal & $\begin{array}{l}\text { Nueva tecnología } \\
\text { intelectual }\end{array}$ \\
\cline { 3 - 5 }
\end{tabular}

Fuente: Elaboración propia, basada en Bell (1973)

Siguiendo el esquema secuencial de las sociedades de Bell (preindustrial, industrial y postindustrial), las ciudades muestran una serie de características diferenciadas para cada uno de ellos. Nuevamente, quiero insistir en la última etapa ${ }^{3}$, la referida a la ciudad postindustrial. Esa ciudad se suburbaniza; aparecen ciudades dormitorio, amplias periferias que desconcentran parte de la población urbana y la integra en antiguos espacios rurales.

\footnotetext{
${ }^{3}$ La ciudad preindustrial se caracteriza por su crecimiento moderado, similar al de los espacios rurales circundantes. Rodeada de murallas, las reformas interiores puntuales aliviaban sólo parcialmente el problema sanitario interior. Con la aparición de la industria, el crecimiento se intensifica y, aunque la ciudad derrumba las murallas y se extiende, mantiene un crecimiento centrípeto. Adopta, a su vez, el nuevo modo de vida con los automóviles como sujeto de especial relevancia en la misma. Cuando las infraestructuras se incrementan y los tiempos de desplazamiento se reducen, con la llegada de la sociedad postindustrial, el crecimiento se vuelve centrífugo. Los centros urbanos dejan de crecer, incluso pierden población, en detrimento de las periferias suburbanas.
} 
Figura 2 - Características de las ciudades en cada etapa

\begin{tabular}{|c|c|c|c|}
\hline Tema & Ciudad preindustrial & Ciudad industrial & Ciudad postindustrial \\
\hline Crecimiento & Moderado & Intenso & Bajo \\
\hline Flujo con el hinterland & Equilibrio & Centrípeto & Centrífugo \\
\hline Planeamiento & Espontáneo-Reforma & Proyectos & Plan. \\
\hline Infraestructuras & Ausencia & Outdoor & Indoor \\
\hline Saneamiento & Ausencia & Medio & Elevado \\
\hline Viario & Animal & Automóvil & otros \\
\hline Equipamiento dotacional & Bajo & Medio & Elevado \\
\hline $\begin{array}{l}\text { Localización actividades } \\
\text { económicas }\end{array}$ & $\begin{array}{l}\text { Integración } \\
\text { especialización } \\
\text { actividades }\end{array}$ & $\begin{array}{l}\text { Concéntricos } \quad y / o \\
\text { Zonificación }\end{array}$ & $\begin{array}{l}\text { Zonificación } \\
\text { segregación }\end{array}$ \\
\hline Modelo Residencia & Casco Histórico & Cuadrícula continua & Polígono Residencial \\
\hline Espacios públicos & Medio & Bajo & Alto \\
\hline Espacios verdes & Outdoor & Indoor & Red. Infraestructura \\
\hline $\begin{array}{l}\text { Filosofía producción } \\
\text { espacio }\end{array}$ & Prefordismo & Fordismo & Postfordismo \\
\hline
\end{tabular}

\section{Fuente: Elaboración propia}

La ciudad recoge, refleja y es producto de los cambios sociales ${ }^{4}$. La ciudad es el escenario del conflicto de intereses de los diferentes agentes que intervienen en ella (Krier, 1992). El interés que mueve a los agentes individuales en la producción del espacio puede ser diferente del colectivo. Este último es crucial, incluso discutible en cuanto a su existencia y preeminencia, además, de diverso y cambiante. De existir, debemos entender el interés colectivo no solo como la suma de los individuales ${ }^{5}$, sino

\footnotetext{
${ }^{4}$ No hay manera de entender la ciudad romana, la medieval o la contemporánea, si no es dando cuenta de esas sociedades, sus características y las transformaciones que supusieron respecto a sus predecesoras. En su interior, las estructuras de poder (y propiedad) gestionan las actividades de sus residentes y visitantes. Prohíben, activan, invisibilizan, fiscalizan, promueven, derriban, ... El poder actúa siempre, sea o no legítimo. Los ciudadanos desempeñan sus roles, incluso poniendo y cambiando las estructuras de poder. Entretanto, viven, trabajan, se divierten, descansan, ... Poder y ciudadanos ejercen un entramado complejo de tensiones que confluyen en intereses diversos produciendo y gestionando el espacio urbano.

${ }^{5}$ Los intereses individuales no sólo están representados por los propietarios, sino por los demás agentes intervinientes en la producción del espacio: promotoras, constructoras, inmobiliarias, arquitectos, ...
} 
como ente con personalidad propia y diferenciada de aquellos. El todo, al menos en este caso, no es la suma de las partes.

El interés colectivo puede medirse a partir de los derechos colectivos que cada sociedad recoge en cada momento histórico. Karel Vasak propuso, en 1977, que la historia del derecho recogía tres momentos o generaciones de los mismos. La primera focalizaba su atención en los individuales, la segunda en los económico sociales y la tercera, basada en derechos de las minorías (de los pueblos y/o de la solidaridad). Todavía podríamos hablar de una cuarta, que podría entenderse como los derechos que superan a "nuestras" sociedades, para incluir a las sociedades venideras y al planeta en su conjunto, tal como se recoge en el concepto de sostenibilidad.

Esas variaciones de demandas obedecen a dos tipos de lógicas: a) por un lado, la transformación de los sujetos colectivos que los promueven y, b) por las coberturas satisfechas de los demandantes que, una vez alcanzan a cubrir ciertas necesidades, pasan a demandar otras nuevas.

Respecto a la primera de las lógicas, el agente social demandante de los derechos individuales era la burguesía; en la segunda generación, es el proletariado. La tercera es promovida por las minorías. La cuarta (la nueva generación de de demandas emergiendo sutilmente en la actualidad), es obra de toda la comunidad, del conunto de la ciudadanía

Figura 3 - Agentes sociales en cada momento histórico de demandas

\begin{tabular}{|l|l|l|l|}
\hline Generación & Momento histórico & Interés colectivo & Agente \\
\hline $1^{\text {a }}$ & Siglos XVIII y ss. & Derechos individuales & Burguesía \\
\hline $2^{a}$ & Siglo XIX y ss & Derechos colectivos & Proletariado \\
\hline $3^{a}$ & Siglo XX y ss & Derechos de minorías & Minorías \\
\hline $4^{a}$ & Siglo XXI y ss. & $\begin{array}{l}\text { Derechos } \\
\text { generaciones }\end{array}$ & Ciudadanía \\
\hline
\end{tabular}

\section{Fuente: Elaboración propia}


Respecto a la segunda lógica, en La revolución silenciosa, Inglehart (1977) descubrió un cambio intergeneracional en los valores de las sociedades industrialmente avanzadas. En su libro El cambio cultural en las sociedades industriales avanzadas, explica y mide más en detalle ese cambio. Con una base de un gran número de encuestas de veintiséis naciones, desde 1970 a 1988, analiza los cambios culturales que se están dando, como el reemplazo de generaciones más viejas por otras más jóvenes, con las consiguientes consecuencias políticas y económicas. El cambio de valores de sociedades materialistas a postmaterialistas se refleja entre otros, en los siguientes aspectos (Figura 4):

Figura 4 - Valores propios de cada sociedad según Inglehart

\begin{tabular}{|l|l|}
\hline MATERIALISTAS & POSTMATERIALISTAS \\
\hline Material & Espiritual \\
\hline Renta & Salud \\
\hline Comer & Bienestar \\
\hline Mantener el orden del país. & Participar de las decisiones políticas. \\
\hline $\begin{array}{l}\text { Luchar contra el aumento dos } \\
\text { precios. }\end{array}$ & Proteger la libertad de expresión \\
\hline Crecimiento económico & Crecimiento sostenible \\
\hline Fuerzas Armadas poderosas. & Estética de ciudades y campos \\
\hline Mantener una economía estable. & $\begin{array}{l}\text { Sociedad menos impersonal y más } \\
\text { humana. }\end{array}$ \\
\hline Luchar contra el crimen. & $\begin{array}{l}\text { Las ideas son más importantes que el } \\
\text { dinero. }\end{array}$ \\
\hline
\end{tabular}

Fuente: Elaboración propia, basado en Inglehart (1977)

\section{TENDENCIAS URBANAS RECIENTES}

Los cambios sociales que hemos comentado ejercen diferentes efectos sobre la ciudad. En concreto sobre el modelo deseado de la misma. Eso explica ciertas transformaciones que observamos en las políticas de planificación urbana. Las tendencias recientes son, en cierta medida, respuesta a la ciudad heredada y a los 
problemas que ésta traía, pero también siguen unos principios de corte político en sintonía con los procesos de cambio social comentados. Es oportuno diferenciar entre las tendencias de la ciudad heredada y las respuestas a esas inercias.

De la ciudad heredada destacamos 5 problemas: la dispersión, la congestión de los centros, la desigualdad a la accesibilidad a equipamientos, la gentrificación y la turistificación.

$1^{\circ}$. La ciudad ha crecido en las últimas décadas pero lo ha hecho con un efecto centrífugo, extendiéndose hacia las periferias, suburbanizándose y generando mucho sprawl (García Docampo, 2014). Aunque también se han producido suburbios altos y compactos, tanto estos como los de bajan densidad, suponen un elevado consumo de suelo, especialmente viario interurbano, una elevada movilidad y dependencia hegemónica del automóvil (Trudeau et al., 2011: 424).

$2^{a}$. En el interior de la ciudad, las elevadas densidades, con el consumo generado, así como el crecimiento del uso del automóvil privado (y del espacio dedicado al mismo) ha conllevado una fuerte congestión en los centros urbanos. La contaminación y congestión has sido generalizadas y prácticamente todas las grandes ciudades han tenido que implementar planes para evitar un colapso de tráfico y de la contaminación generada en los centros urbanos.

$3^{\circ}$. Desigualdad en el acceso a equipamientos y segregación espacial. Las ciudades, por barrios, reproducen el sistema de estratificación social. Cada uno cuenta con diferentes estándares de equipamientos, lo que redunda en una diferente accesibilidad para cada clase o grupo social

$4^{\text {o. }}$ Muchos barrios has sufrido procesos de gentrificación con expulsión de sus antiguos residentes para albergar a clases sociales más elevadas que se ubican en viviendas rehabilitadas con estándares de calidad más altas 
$5^{\circ}$. Las viviendas que tradicionalmente se dedicaban a residencia de la población se dedican ahora, en porcentajes significativos, a albergar a turistas y visitantes (turistificación). La incidencia en el mercado, reduciendo la oferta, incrementando los precios, conllevan expulsión de los residentes menos pudientes. Así mismo, las actividades económicas de proximidad, pierden peso respeto de las utilidades de los residentes, para ganarla respecto de los turistas (De Mattos, 2007).

La reacción reciente del urbanismo, para dar solución a esos problemas, se ha sustentado en cuatro ejes, que funcionan como principios políticos orientadores de la planificación urbana y resultante de los procesos de cambio social observado en las sociedades contemporáneas. Esos principios son:

1) Crecimiento más compacto, superarando el sprawl y resolviendo la excesiva dependencia del automóvil y del elevado consumo de suelo.

2) Demanda de una ciudad más amable, con nuevas modalidades de movilidad más sostenibles y menos tráfico, mejoras en la red de espacios públicos, mayor integración de la heterogeneidad social.

3) Inclusión y accesibilidad urbana, con criterios heterogeneizantes y equitativos

4) Cambios en los modos e gobernanza del territorio, incrementando los niveles de participación, cooperación y planificación

Estos ejes se han integrado de diferente forma en los principales paradigmas urbanísticos contemporáneos. Entre ellos, desatamos tres Kelbaugh (2000, 2007): El Posturbanismo, el Everyday Urbanism y el New Urbanism.

\section{NUEVAS TENDENCIAS EN URBANISMO}

\subsection{Un planeamiento para cada ciudad}


Podemos entender que hasta mediados del siglo XX el urbanismo se apoyaba en proyectos. Ni las herramientas, ni los conocimientos, ni las dinámicas políticas, permitían mucho más. La planificación de la ciudad era por partes, parcial, muy dominada por las élites urbanas, que ya en sí mismas era dominantes en el conjunto de la sociedad. Las primeras legislaciones urbanísticas modernas, como la italiana (1942) y la inglesa (1947) dan el salto del proyecto al plan, pero manteniendo el problema en una cuestión de diseño, aunque la escala se amplíe. Es el momento en el que se generalizan los planes de urbanismo en todos y cada uno de los municipios.

Figura 5 - La planificación de cada ciudad

\begin{tabular}{|l|l|l|l|}
\hline & Ciudad preindustrial & Ciudad industrial & $\begin{array}{l}\text { Ciudad } \\
\text { postindustrial }\end{array}$ \\
\hline Función urbana & Consumo & Producción & Servicios \\
\hline $\begin{array}{l}\text { Relación con } \\
\text { Li.itadand }\end{array}$ & Isla & Nodo & Red \\
\hline $\begin{array}{l}\text { Elujos } \\
\text { Intervención plan }\end{array}$ & Viaje & Transporte & Accesibilidad \\
\hline
\end{tabular}

\section{Fuente: Elaboración propia}

Más recientemente, estamos evidenciando un nuevo cambio. Aparecen las nuevas corrientes del urbanismo que centran su atención en los 4 ejes anteriormente mencionados: Crecimiento sostenible, espacios amables, inclusivos y con participación ciudadana en su diseño. El nuevo urbanismo adopta esta filosofía de manera diferente, entre las cuales aparecen las corrientes del Posturbanim, Everyday urbanism y New Urbanism (Kelbaugh, 2000, 2007).

\subsection{Posturbanism}

En su versión más pura, el Posturbanism está compuesto por elementos y piezas arquitectónicas generalmente grandilocuentes. Introduce las nuevas tecnologías y las funciones que la informática genera en la sociedad, tanto para 
trabajar, divertirse o vivir, para habilitar espacios propios de esa era. Rem Koolhaas, Zaha Hadidi, Steven Holl, Frank Gehry o Daniel Libeskind son algunos de los nombres asociados a esta corriente. En ciertas versiones más soft, se queda en un simple smart growth 6 .

\subsection{Everyday urbanismo}

El Everyday urbanism es práctico, real, ejecutándose diariamente. Valora lo "efímero, la cacofonía, la multiciplidad y la diversidad" (Kalinsky, 2008). Es un urbanismo "conversacional", abierto a las informalidades populistas, que separa el diseño físico del uso social de cada espacio. Fue inicialmente teorizado por Margaret Crawford, John Chase y John Kaliski en 1999. No se preocupa por la estética, sino por las actividades específicas de la vida diaria ${ }^{7}$. Constituye un enfoque empírico que refuerza situaciones y experiencias existentes que a menudo pasan desapercibidas en la vida cotidiana. A diferencia de las prácticas de diseño urbano, Everyday Urbanism no está interesado en la transformación completa de sitios, sino en la intensificación de estas experiencias al "trabajar junto con ellos, encima o detrás de ellos".

\subsection{El New urbanism}

Según Bohl (2000), el nuevo urbanismo es un término genérico que abarca los conceptos tradicionales del vecindario de Andres Duany y Elizabeth Plater-

\footnotetext{
${ }^{6}$ Una densidad más alta de crecimiento (justificada quizá por una referencia a los conceptos de comunidad y de barrio) en torno a núcleos o centros ya existentes (en oposición a la urbanización caótica), se considera más bien como una respuesta a la presión excesiva sobre los espacios públicos, las infraestructuras (escuelas, agua potable, tratamiento de aguas residuales, carreteras) y el medio ambiente (por ejemplo, la pérdida de suelo agrícola o de hábitats de alto valor). El concepto de "crecimiento inteligente" ha cobrado un atractivo nacional en Estados Unidos, como el único camino para reorientar la urbanización sin límites y caótica hacia una vía más eficiente y respetuosa con el medio ambiente.

${ }^{7}$ Por ejemplo, el valor de los espacios públicos y la vida comunitaria está rebosante de mercados callejeros, vendedores ambulantes de alimentos y murales creados orgánicamente; este estallido creado por la vida comunitaria da como resultado mejoras en el espacio público que el "urbanismo cotidiano" entiende como una "mejora por apropiación" o como una apropiación desafiante de lugares en la ciudad con actividades urbanas temporales y efímeras.
} 
Zyberk, las bolsas peatonales de Kelbaugh, los diseños de

Peter Calthorpe y Shelly Poticha, y el enfoque de "quartiers" de Leon Krier (Knaap et al., 2005:109; Jepson et al., 2010; 417). Inicialmente, pretendía superar el sprawl, el aislamiento y mejorar la calidad de vida y la estética de las ciudades (Katz et al, 1994). Sus principios están articulados en la carta del Congreso para el Nuevo Urbanismo (CNU), fundado en 1993 por un grupo de arquitectos, planificadores y defensores del medio ambiente. Hoy, el CNU tiene más de veintitrés mil miembros en el mundo. Actualmente hay decenas de proyectos desarrollándose bajo el prisma de New Urbanism (Knaap et al., 2005: 109). Con frecuencia se cita como ejemplo práctico de New Urbanism el caso de Seaside (Florida).

David Harvey en un artículo publicado en La Vanguardia (Harvey, 2000) señalaba que "El nuevo urbanismo está en la cresta de la ola. Todo el mundo es su entusiasta defensor. Porque, al fin y al cabo, ¿a quién le gustaría que le llamasen 'viejo urbanista'?". En ese artículo clasifica las diferentes versiones en tres grupos: a) La versión Costa Este americana, con su modelo dominante de residencial misto de alta densidad ${ }^{8}$; b) La versión

británica del "pueblo urbano"; c) La versión costa oeste americana, que genera barrios dispersos, integrados interna y regionalmente ${ }^{10}$.

\footnotetext{
${ }^{8}$ Aunque la huella ecológica resultante es de las más óptimas, se trata de ciudades congestionadas en las que sus habitantes siguen dedicando muchas horas a los desplazamientos (eso sí, en transporte colectivo) y habitadas por élites sociales en islas de suburbios más depauperados. Son núcleos urbanos atractivos, con una ingente oferta cultural y elevados niveles de seguridad. El uso residencial está acompañado por el comercial y de ocio. Estos últimos son el objeto de consumo de esas élites, además de focos de atracción de un importante volumen de visitantes que cogestionan aún más esos nodos.

${ }^{9}$ Combina la nostalgia por un período perdido con una pizca de conciencia social e intenta aportar elementos laborales y comerciales a una fisonomía urbana caracterizada por un fácil acceso en la propia localidad. La idea de pueblo urbano goza de un extendido atractivo que abarca a todo el espectro social. Grupos étnicos, comunidades obreras y élites privilegiadas han adoptado esta idea con entusiasmo

${ }^{10}$ Sitúa los núcleos de barrio tradicional en el seno de un plan regional más integrado de infraestructuras de transporte para enlazar los puestos de trabajo espacialmente dispersos, las zonas comerciales y las instalaciones de ocio. Transige, por una parte, con la dispersión de tales factores, pero trata de recuperar los ideales de una convivencia vecinal más íntima y entrañable y de una vida de comunidad.
} 


\section{HACIA UN NUEVO PARADIGMA}

Es evidente que, a pesar de llevar décadas de planes urbanísticos generalizados en todas las ciudades, éstas presentan deficiencias y problemas como los anteriormente mencionados. Recurrentemente escuchamos que el urbanismo está en crisis, o que lo está la ciudad (Rubio Herrera, 2016). Ciertas frases se repiten de un decenio a otro: la crisis del urbanismo, el planeamiento urbanístico en la encrucijada, un nuevo enfoque para el planeamiento, ... La historia del planeamiento urbanístico parece un proceso continuo de introspección y reinvención” (Hebbert, 2000: 82). Pero, frente a los fracasos del urbanismo, la ciudad es pujante. Adopta múltiples formas, se planifica y se escapa del plan ${ }^{11}$. Incluso cambia de escala, de límites físicos, para concebirse más allá de sus periferias suburbanas, hasta integrarse en su región (Borja, 2000).

El siglo XX fue muy dañino para el planeta, casi letal. Tardamos pero actualmente es imprescindible (y urgente) entender que es nuestra responsabilidad cuidarlo. No está totalmente asumida esa defensa sino que tan solo comienza a estarlo. Los nuevos planes urbanísticos han avanzado mucho a este respecto, pero adolecen aún de graves carencias. El Everyday Urbanism, es acusado de mantener el foco en espacios demasiado pequeños, con visión poco global; el Posturbanism aparece, a su vez, como una ficción, además de que, en muchos casos, es incapaz de resolver los problemas de congestión, de perder la escala humana y de ser económicamente caro; el New Urbanism, con frecuencia es tildado de new suburbanism, por mantener aun muy elevada la dispersión (Gordon et al., 2007: 41),

\footnotetext{
${ }^{11}$ Pero tanto el urbanista, como los políticos o cualquiera de los demás agentes que intervienen en la producción del espacio, son conscientes de esa lógica interna de la ciudad. Raramente asumen su responsabilidad; contrariamente, teorizan desde la retaguardia y formulan un "deber ser" en la que se sienten ajenos, "exiliados al mundo virtual" (Koolhaas, 1996: 8).
} 
además de generar espacios falsamente idílicos ${ }^{12}$, socialmente segregativos y homogéneos.

Con lo mejor de la herencia de los nuevos paradigmas urbanísticos y recogiendo las tendencias sociales recientes, podemos caminar hacia un nuevo paradigma, que podemos denominar Urbanismo Sostenible

\section{Figura 6 - Fundamentos teóricos del Urbanismo Sostenible}

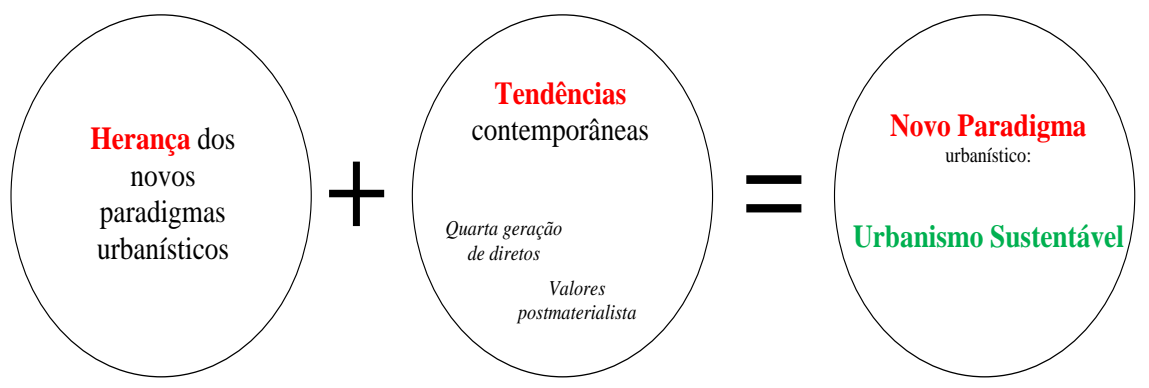

Antes de la generalización de los planes de urbanismo a todas las ciudades (y municipios), la práctica era de realizar proyectos, a escala más pequeña, siempre con la intención de mejorar la calidad de vida de las élites. A partir de mediados del siglo XX comienzan a elaborarse los planes de carácter municipal, democratizando y extendiendo a toda la ciudadanía los beneficios buscados. Pero el Urbanismo Sostenible supera también esa fase, al incrementar la escala (Rueda, 2010) ${ }^{13}$ y entender el planeamiento como una estrategia global, más allá del plan municipal,

\footnotetext{
${ }^{12}$ El nuevo urbanismo rebosa de nostalgia por una idealizada vida de pequeña población y estilo de vida rural que nunca existió. Las realidades de tales lugares estuvieron con frecuencia caracterizadas por un ambiente represivo y limitador, más que por ser realidades seguras y satisfactorias (al fin y al cabo, ésta fue la clase de mundo del cual las generaciones de emigrantes ansiaban huir, y precisamente no acudían a él en tropel). Y además, el nuevo urbanismo, en la manera en que es descrito, muestra señales abundantes de represiones y exclusiones en nombre de algo llamado "comunidad" y "barrio" o "vecindario".

${ }^{13}$ La planificación urbana requiere pasar de una visión del plano a cota cero, del actual urbanismo, a otra que triplica esa visión, añadiendo una capa de subsuelo, otra de planta y una tercera de altura. Cualquiera de ellas es apta para la biodiversidad ecológica. En altura, por ejemplo, las fachadas dejan de ser elementos decorativos para integrarse en el ecosistema captando y reciclando energía, funcionando como soporte vegetal y ampliando las funciones bióticas en su conjunto (Rueda, 2010)
} 
pensando en el planeta y en las generaciones venideras, llamadas a disfrutarlo. Los postulados estratégicos de ese nuevo paradigma son (Talen, 2002):

El planeta, entendido como nuestro hábitat, tiene que mejorar, en calidad y cantidad, nuestra vida, como humanos.

El planeta, con todos sus recursos naturales, tiene que ser conservado, en calidad y cantidad, para el disfruto de generaciones venideras.

El planeta, con todas sus especies, debe ser conservado para el disfrute de todas ellas, superando el antropocentrismo

En realidad se pasa de una sostenibilidad industrial a otra postindustrial, siguiendo el esquema de D. Bell. La sostenibilidad postindustrial: 1) está pensada para generaciones actuales; 2) humanos como centro de referencia; 3) verde como decorado y esparcimiento. La sostenibilidad postindustrial: 1) está también pensada para generaciones futuras; 2) los humanos son una pieza relevante de un ecosistema que es el centro de la sostenibilidad: 3) Lo verde es una infraestructura en red, de manera que los parques urbanos dejan de ser islas para el ocio y esparcimiento humano, para convertirse en parte de una red continua en la que habitan múltiples especies.

Como conclusión podemos centrarnos en tres puntos:

1. Hay síntomas de "cambio social" en nuestras sociedades. Estos cambios afectan a las demandas que, de manera colectiva, asumen la ciudadanía. En concreto, esas demandas, de tercera y cuarta generación (derechos de las minorías y derechos de la ciudadanía, respectivamente) se centran en los valores postmaterialistas y en lograr un hábitat más sostenible

$2^{\text {a }}$. Esos cambios han sido asumidos por una parte de los planificadores urbanos y del territorio. De hecho, es necesario ese compromiso, en defensa del 
planeta. Aunque no está institucionalizado, podemos denominar "urbanismo sostenible a ese nuevo paradigma. En su génesis están, no sólo la tentativa de solucionar los problemas de la ciudad heredada en base a los principios postmaterialistas, sino también todo el bagaje de corrientes como el Posturbanism, el Everyday Urbanism y el New Urbanism.

$3^{\circ}$. Los fundamentos diferenciadores de ese urbanismo sostenible son tres: la necesidad de referirse a la mejora de toda la especie humana, de ésta y próximas generaciones y de hacerlo en armonía con el bienestar del resto de las especies que habitan el planeta.

\section{REFERENCIAS}

Ascher, F. 2001. Les nouveaux principes de l'urbanisme. La fin des villes n'est pas à l'ordre du jour. La Tour d'Aigues : Éditions de l'Aube.

Bell, D. 1973. El advenimiento de la sociedad post-industrial. Madrid: Alianza Editorial, 1991.

Borja, J. 2000. Ciudadanía y espacio público. Revista Foro, (40): 67-80.

Cervero, R., \& Radisch, C. 1996. Travel choices in pedestrian versus automobile oriented neighborhoods. Transport policy, 3(3): 127-141.

Chase, John; Crawford, Margaret; John, Kaliski 1999. Everyday Urbanism. New York: Monacal Press.

Chueca Goitia, F. 1968. Breve história do urbanismo. Lisboa: Presença, 1983.

De Mattos, C.A. 2007. Modernización capitalista y revolución urbana en América Latina: cinco tendencias genéricas. Santiago de Chile

García Docampo, M. 2014. Theories of Urban Dynamics. International Journal of Population Research, vol. 2014.

Gordon, D., \& Vipond, S. 2005. Gross density and new urbanism: Comparing conventional and new urbanist suburbs in Markham, Ontario. Journal of the American Planning Association, 71(1): 41-54. 
Harvey, D. 2000. El nuevo urbanismo y la trampa comunitaria. La Vanguardia, 26/11/2000.

Hebbert, M. 2000. El Grupo de Trabajo-Task Force-y el nuevo enfoque del urbanismo británico. Urban, 4: 82-90.

Hebbert, M. 2003. New urbanism—the movement in context. Built Environment 29(3): 193-209.

Hernández Moreno, S. 2008. Introducción al urbanismo sustentable o nuevo urbanismo. Espacios Públicos, 11(23).

Inglehart, R. 1977. The Silent Revolution. Changing Values and Poltical Styles Among Western Publics. Princenton (N.J.): Princenton University Press.

Jepson Jr, E. J., \& Edwards, M. M. 2010. How possible is sustainable urban development? An analysis of planners' perceptions about new urbanism, smart growth and the ecological city. Planning Practice \& Research, 25(4): 417-437.

Kaliski, J. O. H. N. 2008. Everyday urban design: Towards default urbanism and/or urbanism by design. Writing urbanism. New York, USA: Routledge, 115-119.

Katz, P. 1994. The new urbanism: Toward an architecture of community. New York: McGraw-Hill.

Kelbaugh, D. 2000. Three paradigms: New urbanism, everyday urbanism, post urbanism-An excerpt from the essential common place. Bulletin of Science, Technology \& Society, 20(4): 285-289.

Kelbaugh, D. 2007. Toward an integrated paradigm: Further thoughts on the three urbanisms. Places Journal, 19(2).

Knaap, G., \& Talen, E. 2005. New urbanism and smart growth: a few words from the academy. International Regional Science Review, 28(2): 107-118.

Koolhaas, R. 1996. ¿Qué fue del urbanismo? Revista de Occidente, 185: 4-10

Krier, Leon. 1992. Architecture \& Urban Design 1967-1992. Academy Editions: Great Britain 
Rodriguez, D. A., Khattak, A. J., \& Evenson, K. R. 2006. Can new urbanism encourage physical activity?: Comparing a new Urbanist neighborhood with conventional suburbs. Journal of the American Planning Association, 72(1): 43-54.

Rubio Herrera, Y. C. 2016. El principio de accesibilidad universal como nuevo paradigma urbanístico. Trabajo Fin de Grao. Facultad de Derecho. Universidad de La Laguna

Rueda, S. 2010. L'urbanismo ecologico. Territorio della Ricerca su Insediamenti e Ambiente. Rivista internazionale di cultura urbanistica, 3(6): 127-140.

Talen, E. 2002. The social goals of new urbanism. Housing policy debate, 13(1): 165188.

Terán Troyano, F. 2011. Resurgam (Invocación para recuperar el urbanismo y continuar el planeamiento). Urban, 1: 8-27.

Trudeau, D., \& Mallou, P. 2011. Suburbs in disguise? Examining the Geographies of the New Urbanism. Urban Geography, 23(3): 424-447

Vašák, K. 1990: Les différents catégories des droits de l'homme, en Les dimensions universelles des Droits de 1'Homme, A. Lapeyre, F. de Tinguy, K. Vasak, Burxelles : UNESCO-Bruylant, Bruxelles, 297-316. 


\section{SALUD PÚBLICA Y PLANIFICACIÓN DEL \\ ESPACIO: URBANISMO PARA LA PROMOCIÓN DE LA SALUD}

María José López Rey ${ }^{1}$

\section{INTRODUCCIÓN}

Este trabajo es el resultado una lección magistral desde la Sociología de la Salud, dirigida a los profesionales del diseño urbanístico y la arquitectura para contribuir a una mayor concienciación de estos profesionales hacia los problemas de salud, partiendo de la premisa de que una mejor planificación puede contribuir a una mejora de la salud pública y la calidad de vida de la población.

Tomaremos como punto de partida los Objetivos de Desarrollo del Milenio, documento que en la actualidad determina las Agendas de Desarrollo a nivel mundial, y por tanto de inexcusable referencia. Nos referiremos únicamente a aquéllos que tienen que ver con la salud y el urbanismo.

A continuación nos centraremos en las cuestiones de salud pública, comenzando por su conceptualización, además de la descripción de los principales indicadores para su medición, señalando los principales problemas de salud que aquejan a la población mundial según estos indicadores, principalmente mortalidad y morbilidad.

\footnotetext{
${ }^{1}$ mane@unex.es

Universidade da Extremadura.
} 
Algunos de los principales problemas de salud están relacionados con estilos de vida, y desde la planificación del espacio se puede contribuir a mejorar esos hábitos.

Por otro lado, las ciudades no están de exentas de diversos problemas medioambientales, que condicionan enormemente la salud de quienes las habitan. Se aborda también esta cuestión, mencionando aquellos indicadores medioambientales que deben ser considerados por arquitectos y urbanistas, dada su incidencia en la salud.

En general, a nivel mundial se ha ido tomando conciencia de la problemática medioambiental y existen hoy en día ciudades como Vancouver o Singapur, que son verdaderos ejemplos a seguir en cuanto a su respeto y cuidado del medioambiente.

Finalmente, y dado que estamos tratando este tema desde una perspectiva social, haremos referencia a lo que se conoce como los determinantes sociales de la salud, haciendo referencia a los principales problemas de salud social. Desde la planificación urbanística se puede igualmente contribuir a mejorar la vida de los ciudadanos y ciudadanas que sufren algún tipo de discriminación por su condición física, psíquica o social.

\section{LOS OBJETIVOS DE DESARROLLO SOSTENIBLE DE LA ONU}

Para definir un contexto en el que enmarcar la relación entre el urbanismo y la salud, debemos tener en cuenta ineludiblemente los Objetivos de Desarrollo de la ONU.

Desde que se redactaran los objetivos del milenio, a cumplir en el año 2000, el progreso en cada uno de los ámbitos ha sido muy notorio, sin embargo, la pobreza, el cambio climático, las epidemias... son retos que precisan todavía la atención de los gobiernos de cara a una mejora de la calidad de vida y al desarrollo, pero un 
desarrollo sostenible, que no agote los recursos poniendo en riesgo la herencia y el futuro de las generaciones venideras.

Con este fin, en el año 2015, los líderes de los distintos países mundiales aprueban la nueva Agenda de Desarrollo Sostenible 2030. En esta Agenda se recogen los denominados Objetivos de Desarrollo Sostenible (ODS), 17 objetivos con una frontera de 15 años para ser alcanzados, centrados en 17 prioridades. Se trata de un conjunto de objetivos globales encaminados a la eliminación de la pobreza, la protección del medio y a garantizar la prosperidad para todas las personas que habitan el planeta.

De los 17 objetivos (pobreza, mujeres, educación, trabajo, medio ambiente, salud...) nos centramos concretamente en dos: salud y urbanismo

Con relación a la salud, (ODS 3) las principales preocupaciones de los distintos países que elaboran el documento son:

- Reducir la mortalidad neonatal

- Procurar educación sexual para reducir embarazos no deseados y enfermedades de transmisión sexual

- Erradicar las enfermedades infecciosas como el SIDA o la tuberculosis

- Mejorar la salud mental

- Reducir las enfermedades no transmisibles

- Reducir la siniestralidad

La mortalidad neonatal ha sido considerada uno de los principales indicadores de desarrollo, y son los países con peores niveles de desarrollo los que cuentan con las tasas más altas. La ONU informa que mientras la tasa de mortalidad en niños por debajo de 5 años es de 43 muertes por mil nacidos vivos, en el año 2015, 
lo que supone una reducción con respecto al año 2000 superior al 40\%, sin embargo en el continente africano aún se registran tasas por encima de las 83 muertes.

También en la lucha de las enfermedades infecciosas se han producido grandes logros, así, el SIDA ha dejado de ser una enfermedad mortal en los países más desarrollados, sin embargo ocupa los primeros lugares entre las causas de muerte en los países de menores ingresos.

En occidente son las enfermedades no transmisibles y las enfermedades mentales los principales problemas que aquejan a la población de forma letal.

ONU informa de que las muertes prematuras (antes de los 70 años de edad) debidas a enfermedades cardiovasculares, cáncer, enfermedades respiratorias crónicas o diabetes alcanzaron unos 13 millones en 2015, lo que representa el 43\% de las muertes prematuras en todo el mundo, y el ritmo en que se reducen las prevalencias no es el deseable, en algún caso, como la obesidad o la diabetes, observamos incrementos notorios en los últimos años.

Del mismo modo que ha aumentado la siniestralidad, siendo los accidentes de tráfico la principal causa de muerte de varones entre 15 y 29 años de edad. Estas muertes han aumentado alrededor del 13\% a nivel mundial desde 2000.

El segundo de los ODS que centra nuestra atención es el 11: Ciudades y Comunidades Sostenibles.

Desde principios del siglo XX el planeta experimenta un crecimiento urbano que no tiene parangón. Según ONU, en 2015 más de la mitad de la población mundial vive en urbes cuyo crecimiento ha sido en la mayoría de los casos desordenados, fomentando la creación de guetos y barrios marginales, creando verdaderas bolsas de pobreza en las periferias urbanas. Pero el crecimiento urbano genera además una problemática que tiene que ver con la salud como lo es el incremento de la contaminación atmosférica. Esto se suma a cuestiones como la 
insuficiencia de los servicios básicos e infraestructuras, lo que hace a las ciudades más frágiles y vulnerables ante los desastres.

Finalmente, para concluir este apartado que sirve de contextualización, hemos de hacer referencia a un otro documento más reciente, la Nueva Agenda Urbana sobre la Vivienda y el Desarrollo Urbano Sostenible, Hábitat III. Este documento es el resultado de la reunión celebrada en Quito, Ecuador, el 20 de octubre de 2016, fecha en la que la Asamblea General de las Naciones Unidas, y fue refrendado el 23 de diciembre de 2016.

El documento contiene la Declaración de Quito sobre Ciudades y Asentamientos Humanos Sostenibles para todos, así como el Plan de Actuación. Los principales retos expuestos en este documento se centran, en síntesis, en los siguientes focos de interés:

- Extender la urbanización a todos los niveles de asentamiento

- Integrar la equidad en las agendas de desarrollo

- Fomentar la planificación urbana a nivel nacional y a la expansión de las ciudades

- Aplicar a la urbanización los criterios de los ODS de la ONU

- Fortalecer las disposiciones institucionales

Para lograr todos estos objetivos es imprescindible que haya regulación urbana que cuente con planificación y diseño, además de financiación por parte de los organismos locales, así como una política urbana nacional.

No se hace más hincapié en este apartado, pues toda la información puede encontrarse en la plataforma de Naciones Unidas, y nos centramos a continuación en las cuestiones relativas a la salud pública y cómo desde la planificación del espacio se puede contribuir a mejorarla. 


\section{EL CONCEPTO DE SALUD PÚBLICA Y SU MEDICIÓN}

\subsection{El concepto de salud pública}

En la antigua Mesopotamia, una de las primeras civilizaciones conocidas, hace más de ocho mil años, con la formación de las primeras ciudades comienza a hablarse normas de higiene, lo que podemos considerar como el antecedente más remoto de la preocupación por salud colectiva.

Más adelante, en la antigua Grecia, tres siglos antes de la era cristiana, Hipócrates, considerado el padre de la medicina moderna, y unos siglos más tarde $(200 \mathrm{dc})$ Galeno, reconocen factores medioambientales como cusas de diversas enfermedades.

El doctor Shaw, en la Prusia del siglo XIX suscribía que los factores causales más importantes eran las condiciones materiales de la vida cotidiana de la gente

El médico alemán Virchow, a quien, a finales del siglo XIX, se le reconoce como el padre de la medicina social considera que "la medicina es una ciencia social, y la política no es más que medicina en una escala más amplia. El progreso de la medicina debiera eventualmente prolongar la vida humana, pero la mejoría de las condiciones sociales podría obtener este resultado con mayor éxito y rapidez".

Pero no es hasta 1920 cuando se adopta una definición de salud pública que satisface a la comunidad científica. Es el profesor estadounidense Winslow, bacteriólogo del agua, y creador del primer departamento de Salud Pública en la Universidad de Yale, quien aporta esta definición:

La Salud Pública es la ciencia y el arte de prevenir la enfermedad, prolongar la vida, fomentar la salud y la eficiencia física e mental, mediante el esfuerzo organizado de la comunidad para:

- Sanear el medio 
- Controlar las enfermedades infecciosas

- Educación para la salud y la higiene personal

- Organizar servicios de medicina y enfermaría preventiva

- Desarrollar mecanismos sociales que garanticen a todos los individuos un nivel de vida adecuado para el mantenimiento de la salud

\subsection{Principales indicadores epidemiológicos}

Sentado todo lo anterior, cabe preguntarse ahora ¿cuál es la ciencia que estudia y mide la salud pública? la respuesta es clara: la epidemiología, que no es otra cosa que la demografía de la enfermedad, o cómo se reparten las enfermedades y la muerte entre los distintos grupos sociales. Es necesaria para la planificación previa a la intervención o implementación de políticas y medidas preventivas. Incluso para el planeamiento del territorio y el diseño de la vivienda.

Los principales indicadores que se utilizan en epidemiología para conocer, por ejemplo, los niveles de desarrollo de una población son la Esperanza de vida y de la Mortalidad. La esperanza de vida se mide en años, y hace referencia al número de años que le quedan de vida a un individuo cuando nace, se trata de una estimación que se hace a partir de las tasas de mortalidad, en cada tramo de edad. Obviamente, los países más ricos tienen las esperanzas de vida más altas y al contrario.

La OMS informa de esperanzas de vida por debajo de los 50 años en algunos países del África subsahariana, y por el contrario, entre los países con la población más longeva, con medias por encima de los 85 años, toda la Europa Occidental junto con Japón y Australia y en América, únicamente Canadá y Chile.

\section{Figura 1. Esperanza de vida en el mundo}




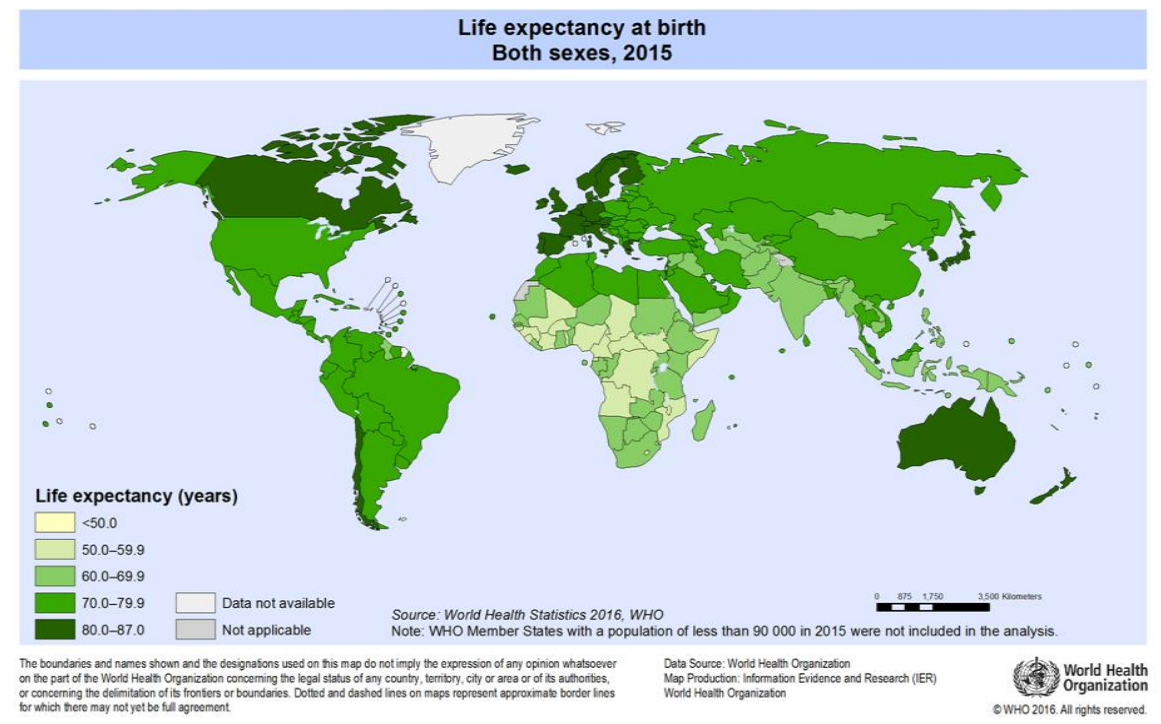

Fuente: OMS, Estadísticas de mortalidad, 2015

La mortalidad es, como se indicó más arriba, otro de los principales indicadores de la salud de una población. La medida de la mortalidad es muy útil para conocer la eficacia de los sistemas de salud, y ayuda a su planificación. Las principales causas de muerte en la población mundial se muestran en las siguientes imágenes obtenidas de la OMS.

Figura 2. Principales causas de muerte en el mundo Top 10 global causes of deaths, 2016

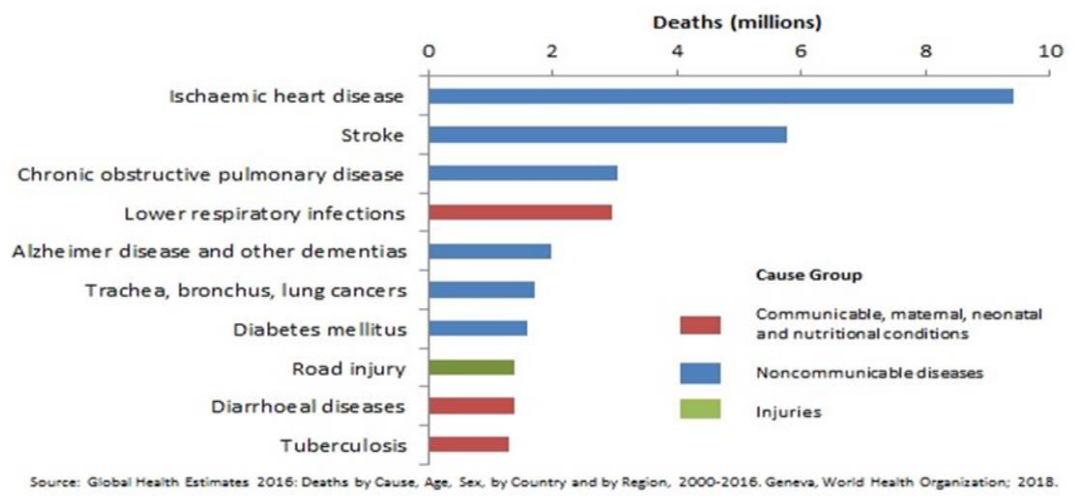




\section{Fuente: OMS, Estadísticas de mortalidad, 2016.}

Si se observa la población mundial globalmente tenemos que decir que lo que causa más muertes son las enfermedades cardiovasculares. Sin embargo es preciso distinguir entre los países más y menos desarrollados, pues, como se verá más adelante, la muerte no afecta de la misma manera a la población en función de sus condiciones socioeconómicas. Así, como se observa en las figuras 3 y 4, mientras las enfermedades infecciosas (infecciones pulmonares, diarreas, SIDA, tuberculosis...) se encuentran entre las primeras causas de muerte en los países con menos ingresos, no aparecen en la lista de las primeras causas de muerte en los países más ricos.

Figura 3. Principales causas de muerte en los países de ingresos bajos

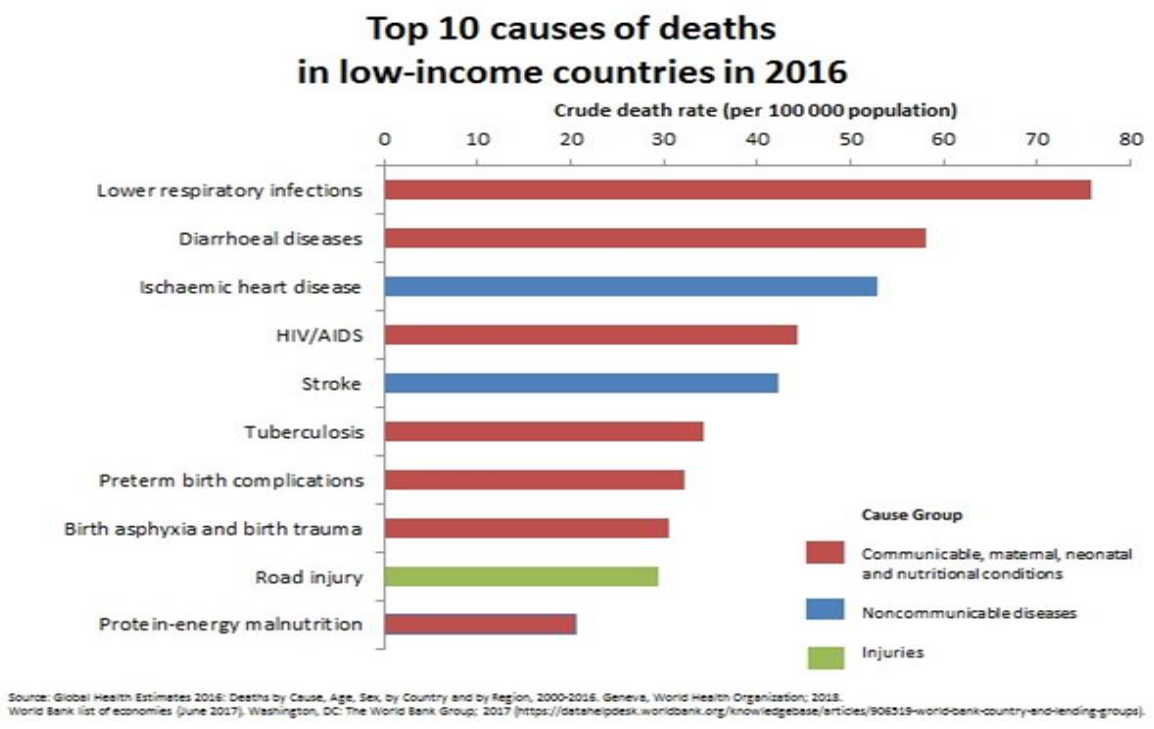

Fuente: OMS, Estadísticas de mortalidad, 2016 
Figura 4. Principales causas de muerte en los países de ingresos altos

Top 10 causes of deaths in high-income countries in 2016

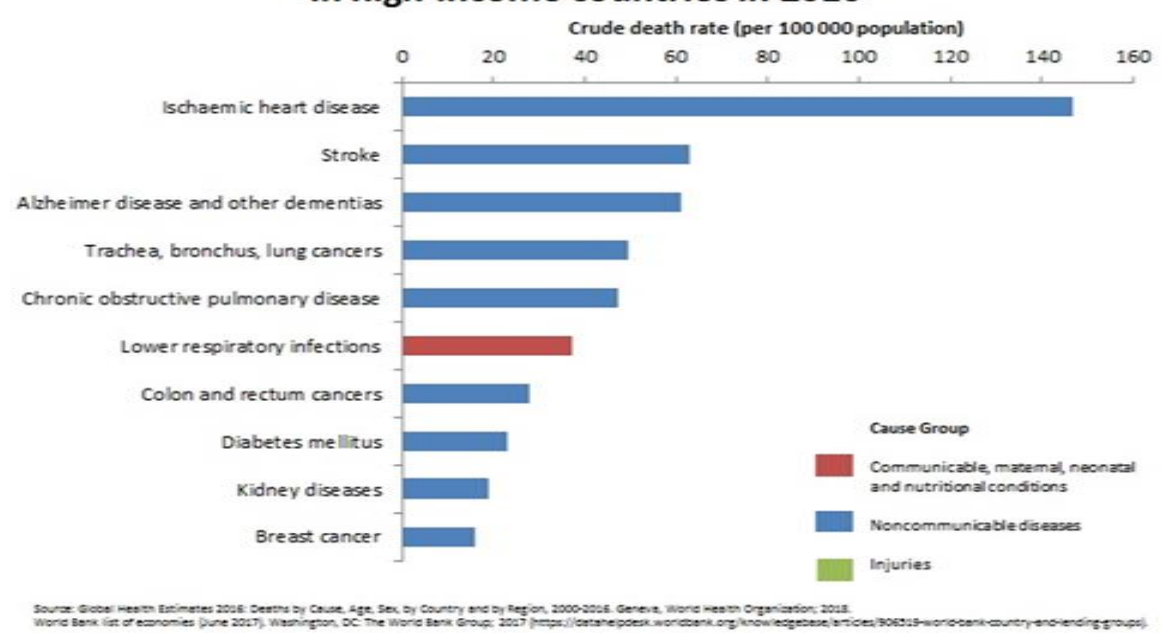

Fuente: OMS, Estadísticas de mortalidad, 2016

Top 10 causes of deaths in high-income countries in 2016

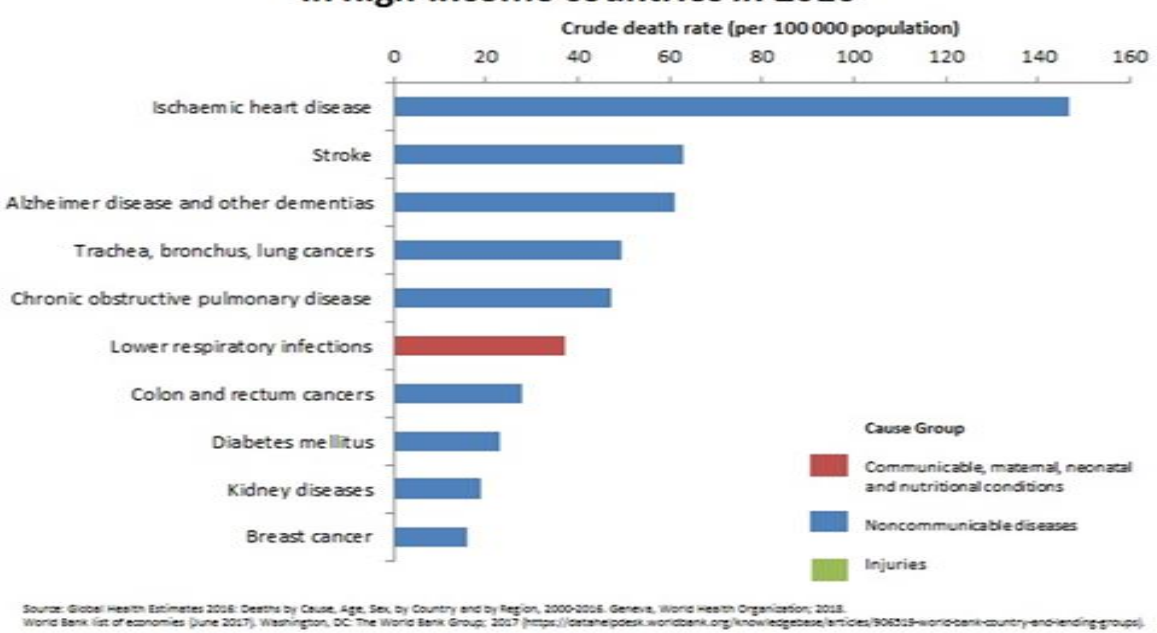

Fuente: OMS, Estadísticas de mortalidad, 2016

El SIDA o la tuberculosis no son enfermedades mortales en los países ricos, sin embargo en estos países aparecen otras causas de muerte que no lo son en los 
países de bajos ingresos, entre ellas algunos tipos de cáncer, la diabetes o diversas enfermedades mentales.

Por otro lado, hay que hacer referencia a los indicadores de morbilidad o presencia de enfermedad, estos dan cuenta del estado de salud de una población. Los más comunes la incidencia, o la ratio de nuevos casos en un período determinado y la prevalencia, que da cuenta del volumen de afectados por una determinada enfermedad.

La enfermedad tiene básicamente dos orígenes, la genética, y los denominados factores ambientales. Sobre los primeros no podemos intervenir desde las ciencias sociales o la arquitectura y el urbanismo, pero sí sobre los segundos, que son los que nos interesan aquí. Los podemos dividir en dos tipos: los externos, ajenos al individuo, propios del medio ambiente, y los internos, que derivan del estilo de vida de las personas. Nos centramos primero en estos últimos.

Las principales causas de muerte están relacionadas con patologías coronarias, que a menudo presentan síntomas como hipertensión, niveles altos de azúcar o de triglicéridos, niveles bajos de HDL (colesterol bueno), o altos de LDL (colesterol malo) u obesidad. Cuando un individuo presenta dos o más de estas patologías es diagnosticado con el llamado síndrome metabólico, sin duda, una de las preocupaciones principales en torno a la salud en el mundo occidental, especialmente si consideramos el incremento de sus prevalencias en los últimos años, como se está viendo con el problema de la obesidad.

Figura 5. $\%$ obesos (IMC >30) 


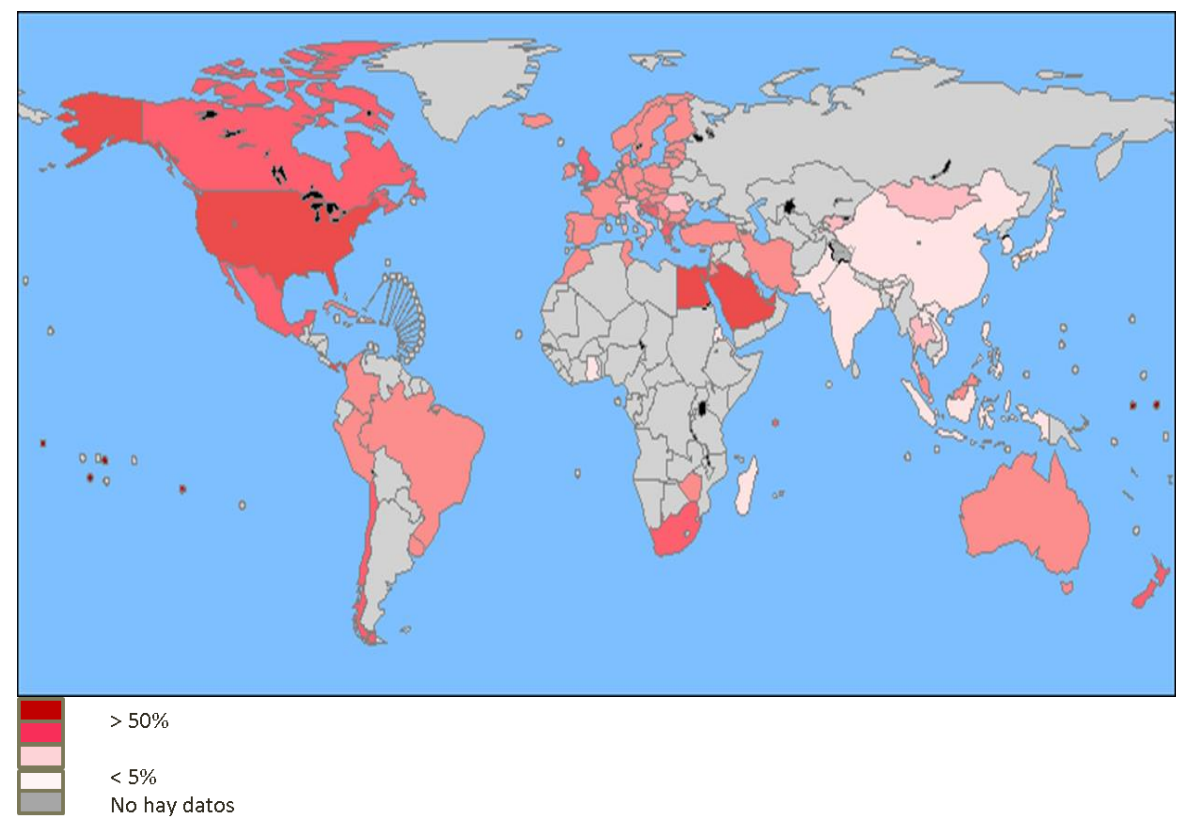

Fuente: OMS, Estadísticas de obesidad, 2018

Según la OMS, desde 1975 la obesidad prácticamente se ha triplicado en todo el mundo. En 2016, el 39\% de las personas adultas, de 18 o más años, tenían sobrepeso, y el 13\% eran obesas. Además, 41 millones de niños menores de cinco años y más de 340 millones de niños y adolescentes (de 5 a 19 años), tenían sobrepeso o eran obesos.

Esta sintomatología, que da lugar a patologías como diabetes o enfermedades coronarias, principales causas de muerte en occidente, está directamente ligada a hábitos muy extendidos entre la población, como una alimentación inadecuada o una vida sedentaria. El consumo de tabaco y alcohol contribuyen también a la carga de morbilidad de las enfermedades no infecciosas.

Desde el urbanismo se puede contribuir a mejorar esta situación, algunos trabajos han demostrado la relación entre una mejor salud de los habitantes en los barrios dotados, por ejemplo, de infraestructuras verdes. Un diseño adecuado puede 
fomentar un cambio en esos malos hábitos generalizados, animando a la población a llevar una vida más sana, posibilitando, por ejemplo, la práctica de ejercicio físico, habilitando espacios verdes, paseos libres de humos, o mejorando las infraestructuras que potencien el uso de la bicicleta.

\section{CONDICIONANTES MEDIOAMBIENTALES DE LA SALUD}

Pero como se decía más arriba, existen otros determinantes de la salud que no tienen relación con el estilo de vida de los individuos, aquellos factores externos que tienen que ver con las cuestiones del medio ambiente.

Entre estos determinantes señalamos en primer lugar el impacto solar, la destrucción de la capa ozono ha dejado a la población desprotegida del impacto de la luz solar, lo que se ha traducido en el incremento del cáncer de piel que se ha observado en las últimas décadas.

La contaminación tanto de la atmosfera como en lugares cerrados es el mayor riesgo para la salud ambiental. A nivel mundial, en 2012 la contaminación del aire en lugares cerrados por cocinar con combustibles contaminantes o tecnologías ineficientes provocó 4,3 millones de muertes, según las estimaciones, mientras que la contaminación del aire debida al tráfico, la industria y la quema de desechos o combustibles residenciales provocó unos 3 millones de muertes. En 2014, 9 de cada 10 personas que vivían en ciudades respiraban aire que no cumplía las normas de seguridad establecidas por la OMS.

También para la OMS, la mala calidad del agua es un importante factor de riesgo de enfermedades infecciosas y mortalidad. La falta de agua potable, de infraestructuras de saneamiento e higiene, son los principales problemas que azotan a la población del África Subsahariana, y Asia Central y Meridional. Las tasas de mortalidad debidas a la falta de esos servicios en ambas regiones fueron de 46 y 23 
por cada 100 mil habitantes, respectivamente, frente a 12 por cada 100 mil en todo el mundo en 2012.

La gestión de los residuos supone uno de los principales servicios ambientales de las ciudades. La basura no gestionada es fuente de enfermedades infecciosas, que pueden llegar también a través del agua.

No cabe duda de que la mejora de la calidad del agua es competencia de la planificación urbanística, que debe considerar las infraestructuras necesarias. Entre los indicadores a los que debe prestarse atención en la planificación podemos mencionar la calidad del agua de los ríos, el volumen e intensidad de los residuos, los niveles de reciclaje o el tratamiento de aguas residuales.

Pero la contaminación no es únicamente del aire, las ciudades adolecen igualmente de contaminación lumínica y sonora. El exceso de luz y de ruido están relacionados con patologías como las jaquecas, los problemas auditivos o el stress.

Finalmente, el desarrollo urbanístico amenaza algunas especies, en las ciudades desaparecen los gorriones y las golondrinas, incluso ardillas y algunas especies de saltamontes; la actividad de las ciudades y los residuos generados ponen en peligro la diversidad también en zonas urbanas. Dejar de escuchar el trinar de los pájaros en la mañana, es perder calidad de vida. Es preciso al planificar prestar atención a las especies protegidas y a los espacios protegidos.

En el mundo son ya varias las ciudades que pueden servir de ejemplo y modelo al hablar de la eficiencia medioambiental. Flandes lo es en el ámbito del reciclaje, y presume del crecimiento en la recuperación de los residuos urbanos más alta de Europa, tal vez por la implantación del sistema conocido como PAYT "Pay As You Throw", que grava con impuestos a los que más basura generan.

Por su parte en Malmö, Suecia, se recicla el 93\% de los residuos. No solo la ciudadanía, sino también los servicios municipales contribuyen al éxito de la gestión 
de sus residuos. Su modelo eco-ciclo incluye instalaciones que generan energía de la basura, reutilización, reciclaje y compostaje.

Milán es la primera ciudad de Europa con un sistema intensivo de separación en origen de sus residuos urbanos orgánicos. Desde 2012 estos residuos se recuperan para compostaje y la fabricación de combustibles, consiguiendo reducir la emisión de gases de efecto invernadero (GEI) en más de un 20\%.

El jardín vertical más grande del mundo, The Tree House, con más de 2.000 metros cuadrados de superficie verde, luce en Singapur, esta ciudad está a la cabeza de los rankings de arquitectura sostenible debido a las políticas que se llevan a cabo en materia de construcción y eficiencia energética. En las últimas décadas la población ha interiorizado la idea de que la basura puede traducirse en recursos, y ya cuentan con alguna electricidad procedente de la basura.

En Noruega, Oslo presume de record mundial: la ciudad que más coches eléctricos tiene por habitante. Allí la prioridad es reducir la contaminación procedente del tráfico, a través, fundamentalmente, de la mejora del transporte público y el fomento del uso de la bicicleta.

Por último, Vancouver, en Canadá, cuenta con un plan de actuación para reducir en un tercio las emisiones de GEIs. La mayor parte de la energía que se consume en la ciudad procede de fuentes ecológicas, además de ser un modelo también en cuanto al reparto de sus zonas verdes.

\section{DETERMINANTES SOCIALES DE LA SALUD}

Nos centramos a continuación en otra cuestión que es, desde hace unas décadas, un nuevo foco de atención de la epidemiología y la salud pública: los determinantes sociales de la salud. Estos se definen como las circunstancias que 
rodean a las personas desde que nacen hasta que mueren, el ambiente en el que se desenvuelven, las condiciones en las que trabajan y viven, como también, los recursos sanitarios a los que tienen acceso. Estos determinantes explican las desigualdades en salud.

La OMS, consciente de las consecuencias que tienen en la salud las diferencias sociales, crea en el año 2005 la Comisión sobre las Desigualdades en Salud, que, con el propósito de mitigarlas, publica en el año 2008 el Informe "Subsanar las desigualdades en una generación”, en el que se afirma:

La mala salud de los pobres, el gradiente social de salud dentro de los países y las grandes desigualdades sanitarias entre los países están provocadas por una distribución desigual, a nivel mundial y nacional, del poder, los ingresos, los bienes y los servicios, y por las consiguientes injusticias que afectan a las condiciones de vida de la población de forma inmediata y visible (acceso a atención sanitaria, escolarización, educación, condiciones de trabajo y tiempo libre, vivienda, comunidades, pueblos o ciudades) y a la posibilidad de tener una vida próspera.

El informe describe entre los principales determinantes sociales estructurales que influyen en la vivencia de la enfermedad, fundamentalmente: la posición social, el género, el territorio de procedencia (raza o etnia), la educación, o la renta, y, señala, además, otros como las condiciones de vida y de trabajo, la disponibilidad de los alimentos, o los que tienen que ver con las políticas gubernamentales y los sistemas de salud.

En síntesis, podemos afirmar que el principal problema de salud social lo constituyen las desigualdades, que pueden ser de diversa naturaleza. Ya nos hemos referido a las desigualdades de clase, y como hemos visto, la salud es peor entre los colectivos más desfavorecidos económicamente hablando. 
En la pobreza encontramos el origen de muchas enfermedades debidas a la mala alimentación, y sobre todo el peor acceso a los recursos sanitarios y educativos, y consecuentemente, la marginalidad.

En los últimos años, en los países más ricos, la población que vive barrios marginales ha disminuido, sin embargo, en números absolutos, este colectivo sigue incrementándose, el aumento puede explicarse, en buena medida, por la falta de una planificación urbanística adecuada.

Pero las desigualdades de clase no son las únicas. Existen otras desigualdades, como la desigualdad de género, o las desigualdades asociadas a la edad, a la raza o las distintas capacidades físicas y cognitivas. Estas desigualdades igualmente pueden ser origen de diversos problemas de salud, a los que el urbanismo y la arquitectura pueden aportar alguna solución. Entre los colectivos más vulnerables, más expuestos a los riesgos de exclusión social hemos de referirnos a:

- Personas en las clases sociales más desfavorecidas

- Mujeres

- Menores de edad y personas mayores

- Personas con capacidades diversas

- Inmigrantes

Las mujeres son víctimas de un problema estructural que las lleva a vivir en peores condiciones de vida y de trabajo, además de sufrir diversos tipos de violencia por el mero hecho de ser mujeres, lo que les lleva a padecer un sinnúmero de enfermedades, sobre todo mentales.

La planificación urbanística no es neutral, adolece de andocentrismo, y ello nos sitúa a hombres y mujeres en diferentes posiciones para el uso y disfrute de los 
distintos espacios, generalmente diseñados sin tener en cuenta la perspectiva de género.

El diseño de los distintos espacios ha estado condicionado por el reparto de roles que la sociedad ha asignado tradicionalmente a hombres y mujeres, así el espacio público es el espacio de las relaciones sociales, el espacio productivo, el espacio extradoméstico, el espacio de los varones; mientras el espacio privado, el de las relaciones familiares, el reproductivo, el doméstico, el de las mujeres.

Si bien, en los últimos años la arquitectura y el urbanismo se muestran más sensibles y concienciados con el rol de la mujer en los espacios públicos, así como del de los varones en los espacios privados, y ya se promueven políticas urbanísticas que consideran las necesidades y demandas de las mujeres. Es necesario, además, implicar a las mujeres en la planificación, así como poner en valor el trabajo reproductivo y diseñar espacios públicos para este fin, y finalmente diseñar el espacio considerando elementos disuasivos de violencia.

El desarrollo y la prosperidad de las ciudades han propiciado diásporas a lo largo de todo el planeta, del éxodo rural, o la migración de las zonas rurales deprimidas a las prometedoras ciudades más próximas, a la migración masiva de los países con menores niveles de desarrollo a ciudades de los países llamados ricos. Este fenómeno ha significado la mezcla de culturas, las principales ciudades del mundo occidental son ciudades multiculturales, en donde conviven culturas, religiones, costumbres, población con distintas necesidades, a la que hay que tener en consideración también a la hora de planificar, especialmente evitando crear guetos y diseñando una ciudad inclusiva, amigable para todos y todas.

Así mismo ocurre con las personas con capacidades diversas, a las que el diseño puede condicionar la vida. Aplicar criterios de accesibilidad es fundamental 
para la integración de las personas que cuentan con alguna dificultad, ya sea de tipo motor, visual o de cualquier otro tipo.

Los mayores son otro de los colectivos al que es preciso prestar atención. La OMS prevé que, en los próximos 30 años, el porcentaje de los habitantes del planeta con más de 60 años se duplicará, uno de cada cinco habitantes pertenecerá a ese grupo etario. La organización advierte que todos los países se enfrentan a importantes retos derivados de este cambio demográfico, que pone en peligro la estabilidad de los sistemas públicos sanitarios.

Figura 6. Proyección de la población mayor de 65 años en el mundo

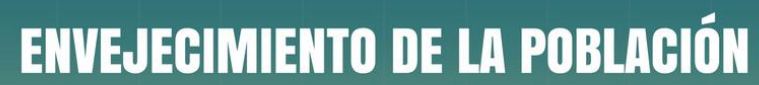

Población mundial proyectada de 60 años y más

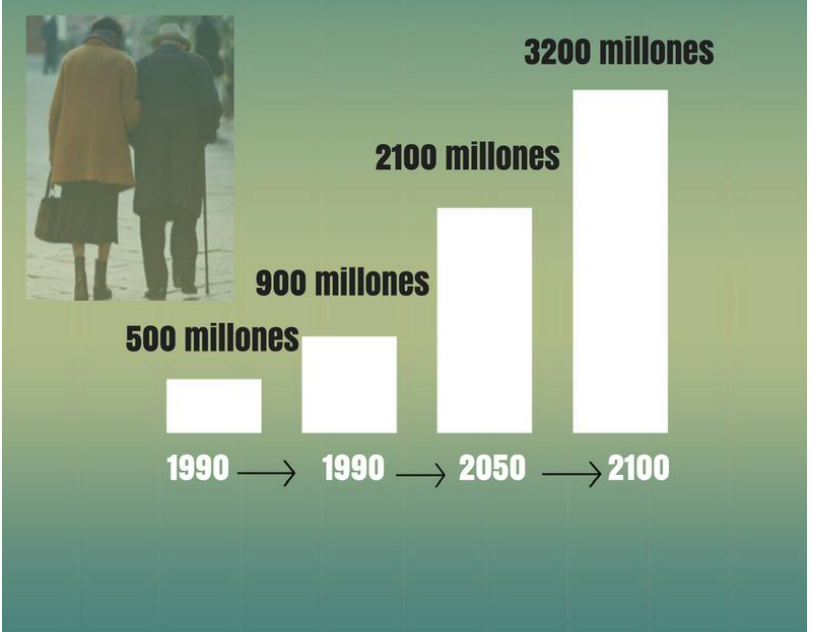

Fuente: ONU, Envejecimiento, 2018

La calidad de vida de las personas mayores puede mejorar en entornos amigables, los espacios y los edificios, tanto públicos como privados pueden condicionar su independencia. Desde la planificación espacial puede promoverse un envejecimiento activo, una ciudad amigable con las personas mayores cuenta con 
espacios verdes, espacios para el descanso, aceras anchas o calles y cruces peatonales seguros.

\section{CIUDADES Y VIVIENDAS AMIGABLES}

Se hará, en este último apartado, una breve referencia a lo que podemos definir como espacios amigables, que tienen en cuenta los problemas de salud a los que nos hemos referido hasta aquí, así como a los colectivos más vulnerables y que precisan mayor atención.

Una ciudad amigable debe contar con un sistema de transporte público socialmente responsable, que cumpla al menos con los requisitos de accesibilidad, para poder ser usado por personas con dificultades motoras, visuales, ... de asequibilidad, que permita que las personas con menos ingresos puedan también ser usuarias, y por supuesto, un transporte respetuoso con el medio ambiente, que no contamine. Algunas ciudades cuentan ya con una red de autobuses autogestionados, con sistemas para recoger y transformar la energía solar. Una ciudad amigable fomenta el uso de la bicicleta como medio de transporte óptimo en las ciudades.

De la misma manera, una vivienda amigable, es aquella apta para personas de cualquier condición. En primer lugar, si pensamos en las personas en riesgo de exclusión social, con bajos o nulos ingresos, las oportunidades de acceso a una vivienda que reúna los requisitos mínimos para su habitabilidad, no siempre están garantizadas. Entre los criterios de inclusión social a tener en cuenta debe considerarse que la vivienda sea económicamente accesible y que cuente con los servicios esenciales como la luz y el agua.

Para hacer viviendas amigables para las personas con capacidades diversas es importante la labor del diseño, que debe emplear materiales sólidos, diseñar habitaciones espaciosas, superficies lisas, a fin de evitar accidentes domésticos, por 
ejemplo, de las personas con deficiencias en su movilidad, como ocurre a menudo con las personas mayores.

La planificación debe ser útil a la promoción de la integración en la comunidad, debe acercar las redes de apoyo social a las personas más aisladas socialmente.

El programa ONU Mujeres recomienda el diseño y la planificación de espacios públicos que contribuyan a la equidad de género, considerando cuestiones como una visibilidad adecuada alrededor del área, que puede ser disuasoria de violencia, y/o reducir la accidentalidad, o situar las áreas de juego, equipadas y señalizadas, cercanas a las casas del entorno, fomentando valores de comunidad, y facilitando una implicación de la vecindad en la vigilancia de niños y niñas. Es importante también que las ciudades dediquen espacios a áreas de juego multifuncionales o áreas especiales para actividades preferidas por las niñas, como por ejemplo, el voleibol.

La ciudad amigable es también responsable socialmente en el sentido medioambiental, la planificación requiere inevitablemente de criterios de sostenibilidad, en la actualidad no puede ya cuestionarse que debemos frenar el consumo de recursos, y crear entornos sostenibles, que no los esquilmen, pues son finitos, y que ponen el riesgo el desarrollo de las generaciones futuras.

El diseño de las calles, parques y plazas constituyen infraestructuras sociales de capital importancia a la hora de fomentar las diferencias entre los distintos espacios de la ciudad, así, los espacios que proporcionan una mayor calidad de vida son aquellos que están bien iluminados, pero sin excesos de iluminación, que cuentan con abundantes zonas verdes, que disponen de corredores caminables, que permiten recorrer ciertas distancias, o acceder a servicios comunes caminando y con seguridad, accesibles, con una buena gestión de residuos, libres de humos y ruidos, y 
por supuesto cuentan con normativas y planes que permitan la conservación y el mantenimiento.

\section{A MODO DE SÍNTESIS}

Para concluir, y a modo de síntesis queremos insistir en tres cuestiones fundamentales, necesarias o de obligada consideración en cualquier iniciativa de planeamiento urbanístico:

1 Emplear criterios urbanísticos de planeamiento: arquitectura verde, ciudades sostenibles y saludables

2 Prestar atención a la diversidad: diseño para todo/as, ciudades inclusivas y viviendas amigables

3 Emplear metodologías participativas: en el ámbito del urbanismo y la arquitectura, es indiscutible la necesidad de contar con las personas que habitará el territorio o la vivienda que se diseña. Algún ejemplo de metodologías participativas son la denominada Investigación-Acción- Participación o IAP, u otra más novedosa, conocida como OASIS, original de la ciudad de Curitiva, y que ha demostrado éxito en la labor de crear comunidades, implicando a las comunidades.

\section{ANEXO}

ONU, Envejecimiento, 2018

OMS, Estadísticas de mortalidad, 2015

OMS, Estadísticas de mortalidad, 2016

OMS, Estadísticas de obesidad, 2018

En los siguientes enlaces puede encontrarse ampliada la información expuesta. 


\section{SITES: ACCESO EN MAYO DE 2018.}

http://www.undp.org/content/undp/en/home/sustainable-development-goals.html http://habitat3.org/

http://www.who.int/es

https://www.solucionesintegralesendesa.com/blog/sostenibilidad/innovacionhogar/las-ciudades-mas-verdes-del-mundo/

http://www.simlevante.com/en/noticias/item/67-gestion-residuos-urbanos.html http://apps.who.int/iris/bitstream/handle/10665/43805/9789243547305_spa.pdf;jsess ionid=E568BCAD54F7E40FF0D9DE6924B067BD? sequence $=1$

http://www.milenio.com/estados/espacios-publicos-seguros-para-mujeres-y-ninas 


\section{AS CIDADES VERDES DA GUINÉ-BISSAU}

Manuel de Carvalho e Sousa ${ }^{1}$

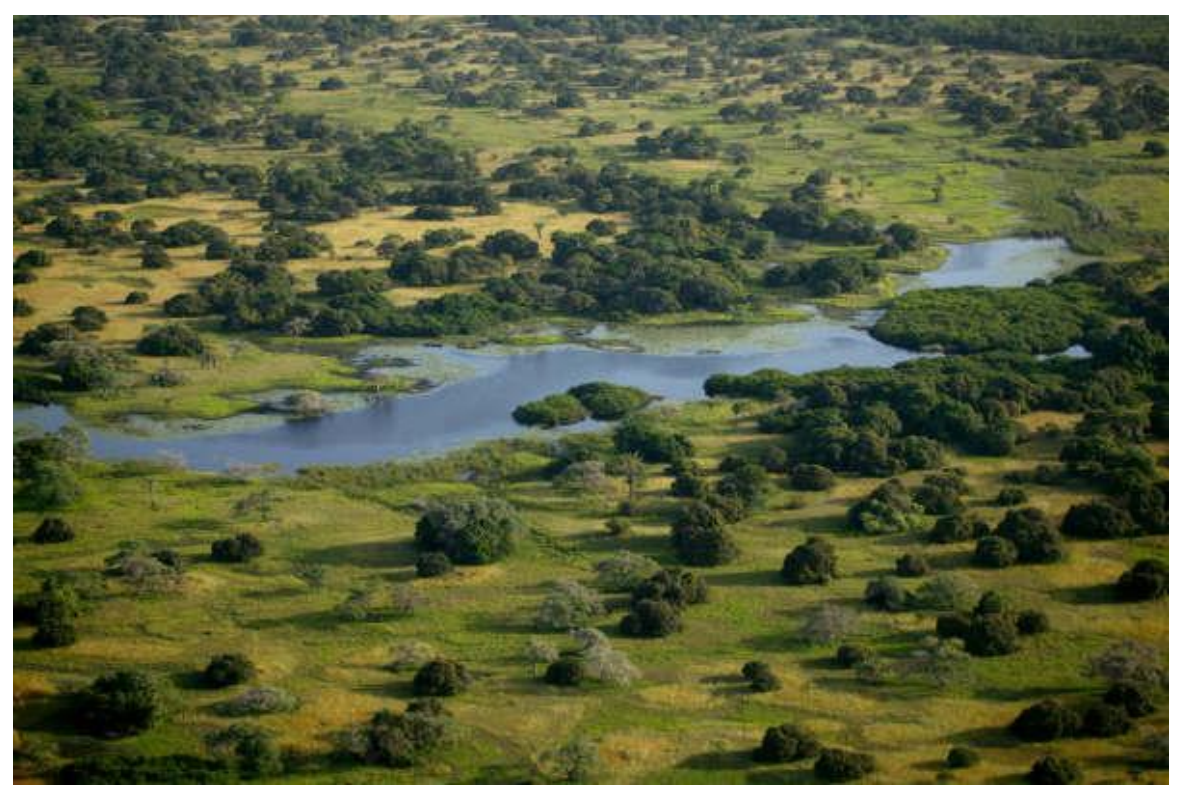

${ }^{1}$ manuel.sousa@isag.pt

Instituto Politécnico de Viana do Castelo, Instituto Superior de Administração e

Gestão, no Porto 


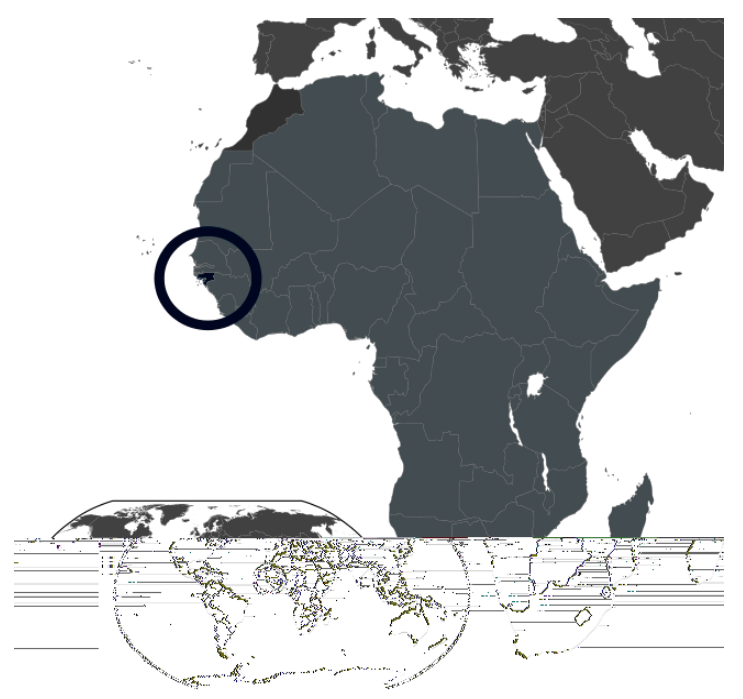

PREÂMBULO

A Guiné-Bissau tem em curso o planeamento urbano de quatro cidades, designadamente Bafatá, Bissau, Bolama e Cacheu, em que numa primeira fase de planeamento apenas se interveio nos Centros Históricos destas cidades e em algumas zonas de Bissau junto às áreas que tiveram planeamento no período colonial.

Pretende-se preparar os bairros, as cidades e o estado com um novo modelo de desenvolvimento ajustado à sua realidade sociocultural, ao clima e os recursos económicos disponíveis, de modo a proporcionar um desenvolvimento económico e social acelerado. Este desenvolvimento terá necessariamente que ser em equilíbrio com a natureza, com a otimização dos recursos disponíveis, com as melhores práticas ambientais e com as tecnologias necessárias para permitir ao cidadão o acesso à informação, a um ambiente de qualidade e ao aumento da sua capacidade económica.

\section{CONCEITO}


As cidades que vão ser intervencionadas serão bem ordenadas, de modo a serem economicamente viáveis e a propiciarem um desenvolvimento harmonioso, para uma melhoria da qualidade de vida da população. Este modelo de desenvolvimento proposto inclui as melhores práticas ambientais e os mais atuais conceitos de desenvolvimento.

A implantação no terreno deste novo modelo de planeamento requer naturalmente boa governança, conhecimento técnico e confiança no sector público, para que se a crie um ambiente que favoreça o investimento privado e o desenvolvimento económico.

A procura das melhores soluções de desenvolvimento será o resultado de uma discussão alargada de técnicos de planeamento, de políticos e dos lideres da população, com uma visão exterior e outra interna, que permita definir o modelo de desenvolvimento mais ajustado e o modo de implementação adequado, para que o cidadão perceba o que lhe é proposto e se reveja neste modelo.

Uma cidade bem planeada e organizada é hoje fundamental para se captar investimento, quer ao nível do turismo, como dos outros serviços, do comércio e da indústria. $\mathrm{O}$ bom planeamento prevê uma boa mobilidade, uma zonagem da cidade, uma compatibilização das atividades económicas, uma definição ajustada dos equipamentos a propor, o conforto bioclimático e uma boa imagem urbana.

Estas cidades foram já alvo de planeamento urbano no período colonial em algumas das suas áreas, pelo que o processo atual é de reurbanização, planeando de forma a valorizar os elementos notáveis do espaço urbano e tendo em conta a expansão atual das áreas habitacionais.

Neste modelo de desenvolvimento urbano terá que ser o de uma cidade ser sustentável, com uma boa estrutura verde urbana que integre parques e jardins públicos, onde está prevista a Estrutura Verde Urbana que integrará a Estrutura 
Verde Secundária com a localização dos espaços verdes urbanos de recreio e a Estrutura Verde Principal com todos os espaços verdes de enquadramento e de estabilidade biofísica, de modo a que o espaço urbano se interligue com os espaços naturais.

Estas cidades foram já alvo de planeamento urbano no período colonial em algumas das suas áreas, pelo que o processo atual é de reurbanização, planeando de forma a valorizar os elementos notáveis do espaço urbano e tendo em conta a expansão atual das áreas habitacionais.

Neste modelo de desenvolvimento urbano terá que ser o de uma cidade ser sustentável, com uma boa estrutura verde urbana que integre parques e jardins públicos, onde está prevista a Estrutura Verde Urbana que integrará a Estrutura Verde Secundária com a localização dos espaços verdes urbanos de recreio e a Estrutura Verde Principal com todos os espaços verdes de enquadramento e de estabilidade biofísica, de modo a que o espaço urbano se interligue com os espaços naturais.

Com esta proposta de planeamento, as cidades interagem mais com a natureza, pois apesar de não desaparecer do espaço urbano, quando a estrutura verde urbana não é robusta a sua interação é débil. As cidades são uma natureza transformada, mas podem estar em equilíbrio com essa mesma natureza e é isso que se pretende que venha a acontecer.

Segundo a Food and Agiculture Organization (FAO), em 2025 mais de metade da população do mundo em desenvolvimento será urbana e por isso urge pensar as cidades como espaços de desenvolvimento económico, social e ambiental e não apenas de crescimento sem planeamento. 
A maioria das cidades que mais crescem no mundo encontram-se nos países de baixo rendimento per capita da Ásia e África, com populações jovens como é o caso da Guiné-Bissau.

A falta de ordenamento do território e de urbanização nos países de baixo rendimento económico é acompanhada naturalmente de altos níveis de pobreza, de desemprego e insegurança alimentar, e com poucos acessos a serviços básicos de saúde, água e saneamento.

Um futuro melhor para as cidades em desenvolvimento é tanto imperativo quanto possível, desde que haja um bom planeamento, boa governação, justiça e segurança, qualidade ambiental, bons equipamentos de saúde e um bom sistema educativo.

O desafio consiste em desviar a urbanização de seu rumo atual, nalguns casos pouco sustentável, para cidades mais verdes, mais sustentáveis, que ofereçam opções, oportunidade e esperança a seus habitantes.

O conceito de Cidade Verdes incluiu um conceito de cidade mais robusta, mais resiliente mais autossuficiente em termos alimentar e energético e com sustentabilidade social, econômica e ambiental. Este conceito está usualmente associado ao planeamento urbano em países mais desenvolvidos, mas nada impede que se aplique na Guiné-Bissau, porque se pretende que este país passe a aplicar as melhores e mais atuais práticas de desenvolvimento urbano.

Um dos pontos de partida para criar cidades mais verdes é o de reconhecer e integrar nas políticas de planeamento urbano muitas das soluções criativas que a população com menos recursos já desenvolveu, geralmente por necessidades para fortalecer as suas comunidades e melhorar sua vida. Algumas destas soluções são por vezes muito bem concebidas e não podem ser desprezadas porque funcionam, fazem parte dos hábitos da população e tem intrínseco um conhecimento ancestral. 


\section{HORTICULTURA URBANA}

Uma dessas soluções, que é um aspeto essencial do planeamento de cidades verdes é a horticultura urbana e periurbana, pois muita da população urbana da Guiné-Bissau em está desempregada ou são trabalhadores mal pagos, situando-se muitos deles ao nível da pobreza. Esses pobres urbanos gastam a maior parte dos seus recursos financeiros para se alimentar, obrigando-se ainda a cultivar seus próprios alimentos para poder garantir uma base alimentar satisfatória. Geralmente usam qualquer pedaço de terra disponível, o mais próximo possível da sua habitação, para criarem o seu espaço de horta.

É essencial que estas hortas passem a ser bem dimensionadas e com uma adequada rotação das culturas para produz adequadamente e se conseguir o equilíbrio nutricional. A desnutrição nas áreas urbanas é por vezes tão alto como nas áreas rurais, até porque os animais domésticos são aqui em reduzido número e portanto, com menor acesso à proteína animal.

A horticultura pode ser rentável até mesmo em pequena escala, podendo assegurar a alimentação familiar e ainda vendendo o excedente e assim ser assumido como uma base do desenvolvimento económico. Para se poder dar o primeiro impulso, será fundamental planear bem os espaços de hortas nas áreas da Estrutura Verde Principal, que são também geralmente as áreas com maiores disponibilidades de água e com maior capacidade produtiva.

Com o desenvolvimento agrícola e o aumento dos recursos financeiros permitirá o investimento na criação progressiva de animais, o processamento de alimentos e confeção de roupas, o desenvolvimento de produtos artesanais de valor cultural, podendo ser aqui o microcrédito assumir um papel de instrumento financeiro relevante. 
Para além da mais-valia económica, a agricultura urbana poderá ter também um papel importante na gestão de resíduos, pois absorve águas residuais e resíduos orgânicos, reduzindo os riscos para a saúde e aumentando naturalmente a produção de alimentos frescos.

Em termos ambientais, a agricultura urbana reduz também a necessidade de transportar produtos das áreas rurais para as cidades, gerando uma redução do consumo de combustível, uma menor emissões de dióxido de carbono, uma menor poluição do ar por fumos e poeiras e um abaixamento da temperatura ambiente. Em relação ao solo, ajudam a manter a estrutura e porosidade deste, o que melhora a recarga dos aquíferos e reduz escorrimentos, prevenindo os desabamentos e as inundações.

Para este modelo de Cidade Verde, a questão da agricultura urbana é fundamental, pelo que para cada cidade se deveria criar um Comité de Gestão da Agricultura Urbana, que teria a função de atribuir os talhões planeados das hortas comunitárias em espaço urbano, que faria a gestão de um banco de sementes, de ferramentas e fertilizantes, para além da formação e do apoio técnico que teria que ser prestado.

\section{ESPAÇOS VERDES}

Os espaços verdes urbanos de recreio terão depois de ser alvo de planeamento específico, podendo neles se implementarem espaços de hortas recreativas, hortas pedagógicas, jardins temáticos, concursos de jardins, espaços desportivos e de prática de exercício físico, pelo que nesta fase apenas se fez o planeamento das tipologias de espaços a criar, como seja o parque da cidade, o jardim botânico ou o parque desportivo.

\section{REABILITAÇÃO URBANA}


A arquitetura de reabilitação ou de construção deverá ser também ela verde, de baixo carbono na sua construção e pela utilização de materiais locais, com ventilação cruzada, com recurso a painéis solares para aquecimento de água e produção de energia elétrica, com sombreamento de paredes pelas coberturas e pela arborização e pela inserção na paisagem pelas volumetrias, pelas cores e pelas formas.

Os edifícios que forem planeados em termos de edifícios públicos terão que ser globalmente bem planeados e bem adaptados ao clima, para terem uma maior durabilidade, maior conforto e melhor utilização. Os edifícios com boa arquitetura são naturalmente um melhor investimento público, pela valorização do espaço urbano, pela sua facilidade de conservação, pela facilidade das rotinas de manutenção e por manterem uma boa imagem ao longo do tempo.

\section{ENSINO}

As escolas do ensino básico deverão ser transformadas em Centro Educativos, em que para além das salas de aula, haja outros espaços de apoio ao desenvolvimento das crianças da Guiné-Bissau, designadamente com um local de preparação das refeições, com um recreio coberto e um parque de recreio infantil.

\section{MOBILIDADE}

Neste processo de reurbanização será necessário criar um novo modelo de cidade que permita articular os edifícios existentes com os novos equipamentos que será necessário construir, mantendo-se a harmonia do espaço urbano e redesenhando as vias de acordo com esta realidade. Será também fundamental dar uma atenção especial as questões da mobilidade, com o planeamento de uma rede de transportes públicos que seja articulada entre si e com os meios de transporte individual, preferencialmente ciclável. 
A bicicleta é hoje assumida como uma alternativa de mobilidade urbana para curtas e médias deslocações, como alternativa ao transporte individual nas cidades da Guiné-Bissau. As cidades por serem relativamente planas requerem muito pouco esforço de locomoção e têm um baixo custo de aquisição e de manutenção, para além de contribuírem para a boa forma física do utilizador.

Para se promover o uso da bicicleta é fundamental criar ciclovias com sinalética adequada, que nesta primeira fase serão apenas vias dedicadas em algumas faixas de rodagem, com a sua demarcação no pavimento de forma a propiciar uma circulação segura e dando um sinal claro da afirmação deste meio de transporte.

Se numa cidade as pessoas se movimentam facilmente, os cidadãos não perdem tempo em engarrafamentos e isso é também um fator que contribui para a qualidade de vida. É naturalmente bom para a economia, porque é bom para o comércio, é bom para os negócios e é bom para o turismo.

\section{ILUMINAÇÃO PÚBLICA}

A iluminação pública sempre que possível deverá ser fotovoltaica, que para além de não ter custos de fornecimento de energia não implica a criação de infraestruturas de rede elétrica de fornecimento de energia. As iluminarias por terem acoplado o painel fotovoltaico e a bateria tem um custo acrescido em relação às iluminarias convencionais, mas no global e perante a realidade da Guiné-Bissau terão uma relação custo/benefício inferior.

\section{ALTERAÇÕES CLIMÁTICAS}

Este planeamento urbano será um planeamento resiliente, adaptando as cidades para as futuras alterações climáticas que provocam a subida do nível das águas do mar, a alteração do regime e da intensidade da precipitação, fenómenos atmosféricos adversos, as alterações da temperatura, o que obriga a planear com estas 
premissas de base, para que o resultado seja um planeamento seguro, com conforto bioclimático e estável a longo prazo.

\section{RESÍDUOS E EFLUENTES}

Com o desenvolvimento económico e social espectável vai haver um aumento de consumo e um naturalmente aumento dos resíduos e dos efluentes, pois de outras sociedades sabemos que existe uma correlação entre o crescimento e a quantidade de resíduos. Aqui o desafio é o de encontrar as melhores práticas ambientais para fazer face a esta situação que irá naturalmente surgir, implementando políticas economicamente viáveis de recolha de materiais recicláveis, de compostagem de resíduos orgânicos de forma individualizada ou coletiva e a criação de estações de tratamentos de águas residuais com plantas macrófitas, que absorvem a água e os nutrientes através da vegetação, que é cortada regularmente.

A compostagem permitirá a produção de um fertilizante orgânico, que potenciará a produção agrícola, essencialmente no que se refere às hortas de caracter familiar, que são essenciais para o equilíbrio da dieta alimentar da população.

Cara cidade deverá ter um parque de reciclagem público, para onde são removidas as sucatas, árvores e lenhas abandonadas no espaço urbano e será o local de depósito de eletrodomésticos em fim de vida.

Os resíduos da construção civil deverão integrar este parque de reciclagem, com um depósito em cada cidade, com a separação dos inertes das madeiras e materiais metálicos, que deverá ficar junto ao local de processamento de materiais reciclados, num denominado ecocentro.

A reciclagem criará um novo mercado na Guiné-Bissau e consequentemente novos empregos, nos serviços de recolha, no armazenamento, no enfardamento e no transporte destes resíduos, que numa primeira fase poderiam ser para exportação e 
eventualmente os CDR's (Combustíveis Derivados de Resíduos) pelo seu baixo valor comercial poderem ser utilizados para alimentar uma central termoelétrica, que poderá ser complementada, com a queima de biomassa

\section{FASEAMENTO}

Para a implementação deste modelo de Cidade Verde é necessário um conjunto de ações sequenciais para a sua implementação, ao nível do levantamento, do planeamento, da discussão pública e da implementação dos projetos no terreno.

$\mathbf{1}^{\text {a }}$ Fase - Levantamento topográfico, do parque habitacional, dos equipamentos públicos, das infraestruturas existentes, das redes de água, das redes de saneamento, das redes elétrica, das redes de comunicações e de outros elementos relevantes.

$2^{\text {a }}$ Fase - Elaboração do Plano de Desenvolvimento Urbano de cada uma das cidades intervencionadas, com definição dos edifícios e das áreas a preservar, da Estrutura Verde Urbana ao nível da matriz arbórea da cidade e das Estruturas Verdes Principal e Secundária, com a definição das áreas urbanas e urbanizáveis, com a definição da rede e hierarquia viária, localização dos equipamentos públicos de acordo com o Plano Nacional de Desenvolvimento e Ordenamento do Território e definição das tipologias de espaços verdes a implementar nas áreas da Estrutura Verde Urbana.

$3^{\text {a }}$ Fase - Apresentação e Discussão Pública dos Projetos com os decisores públicos e com a população em geral.

$4^{\text {a }}$ Fase - Alterações ao projeto resultantes das apreciações dos decisores e das sugestões aprovadas pelos decisores resultantes da discussão pública, com vista à aprovação do Plano de Desenvolvimento Urbano.

$5^{\mathbf{a}}$ Fase - Calendarização e orçamentação das intervenções no espaço urbano. 
$6^{\circ}$ Fase - Elaboração de projetos específicos ao nível do projeto de execução.

$7^{\mathrm{a}}$ Fase - Adjudicação das Obras.

8$^{\mathbf{a}}$ Fase - Fiscalização de Obra. 


\section{GESTÃO DE RESÍDUOS DE CONSTRUÇÃO E SUA APLICAÇÃO EM CONCRETO}

Lia Lorena Pimentel ${ }^{1}$

\section{GERAÇÃO DOS RESÍDUOS DE CONSTRUÇÃO}

A construção civil é um setor altamente impactante no Meio Ambiente, todas as necessidades do ser humano exigem a construção de edificações, quer seja para moradia, fabricas para produção de bens de consumo, ou infraestrutura urbana, como estradas hospitais e saneamento básico.

Atualmente o PIB Brasileiro é de R\$ 5,7 trilhões e a indústria da construção civil é responsável por $6,2 \%$.

Com isso esta indústria causa 3 grandes impactos:

O primeiro é o grande consumo de matéria prima cerca de 40 a $75 \%$ de toda matéria prima extraída no mundo.

Um exemplo é o consumo de agregados, no Brasil nos anos de 16 e 17 o consumo foi da ordem de 750 milhões de toneladas, com a crise se previu uma retração no mercado, porem o Brasil tem uma carência de infraestrutura muito grande com isso a demanda deve aumentar após a crise financeira. (ANEPAC, 2014)

O segundo impacto é a modificação da paisagem, muitas vezes decorrente da exploração da matéria prima como a extração de brita para pavimentação e produção de concreto, ou da extração de areia ou mesmo a extração de minério para produção de cimento, de cal ou de aço. Sem contar a poluição atmosférica.

\footnotetext{
${ }^{1}$ Coordenadora do Programa de Mestrado em Sistemas de Infraestrutura Urbana PUC Campinas

lialorenapimentel@gmail.com
} 
O terceiro impacto é a geração de resíduos, que são depositados em ruas, ou em áreas de preservação ambiental, deteriorando o Meio Ambiente e permitindo a criação de vetores transmissores de doenças.

A quantidade de resíduos gerada é muito grande. Se considerarmos a taxa de geração de RCD de 500 quilos de entulho/ habitante por ano, para a população do Brasil de um pouco mais de 200 milhões de habitantes teremos aproximadamente 103,8 milhões de toneladas de RCD em um ano.

Segundo a ABRELPE 2016, os municípios Brasileiros coletaram cerca de 45,1 milhões de toneladas de RCD em logradouros públicos.

A ABRECON/Miranda (2016) fez um levantamento em 2015, e estima que apenas $21 \%$ do RCD gerado no Brasil foi reciclado nos últimos 5 anos.

Esses dados fazem da construção civil a indústria mais poluente do planeta.

\section{GESTÃO DOS RESÍDUOS}

Um levantamento da Comissão Europeia em 2015 aponta que alguns países como Inglaterra e Alemanha que geram gde quantidade de RCD conseguem reciclar mais de $70 \%$ dos resíduos.

Países como a Dinamarca e Holanda conseguem reciclar mais de $90 \%$ do resíduo gerado.

Isso se deve principalmente a políticas públicas adotadas impondo taxas sobre a extração de minerais e sobre deposito de RCD em aterros o que obriga a adoção de materiais reciclados nas construções.

Os resíduos gerados pela indústria da construção são classificados pela resolução Conama $307 \mathrm{em}$ :

Classe A - Resíduos de argamassa, concreto, cerâmica, rochas, solo... 
Classe B - Madeira, vidro, aço, papel e papelão, gesso...

Classe C - resíduos para os quais não existem tecnologias de reciclagem economicamente viáveis.

Classe D - resíduos perigosos como tintas, óleos, amianto.

Os resíduos Classe A e B são economicamente rentáveis, os classe B podem ser reciclados em suas respectivas cadeias produtivas e as classes A - que representam 90\% dos RCD podem ser triturados e utilizados como agregados para as mais diversas finalidades, como pavimentação, produção de argamassa e concreto.

Para tornar a indústria da construção mais sustentável é fundamental aplicar os preceitos da SUSTENTABILIDADE.

Dentre estes preceitos, a preocupação com a geração de resíduos é muito forte, devido a grande quantidade de resíduos que esta indústria gera. Então se deve buscar primeiramente a:

Não geração de resíduos - a redução da geração passa pela implantação de novas tecnologias, pela racionalização da construção e pelo planejamento de todo o processo construtivo.

Re-uso - não tem aplicação direta dos RCD na forma como são gerados

Reciclagem - propicia a geração de produtos cuja principal aplicação hoje em dia é a pavimentação, mas existe a possibilidade de aplicação em varias outras áreas como: camadas de fechamento de aterros sanitários, recuperação de áreas degradadas, produção de tijolos, de argamassa e de concreto

Deposição adequada dos resíduos - Os RCD não podem ser depositados em Aterros Sanitários (conforme Lei 12.305/2010), caso não sejam processados devem ser dispostos em aterros de inertes. 
Com o aquecimento do mercado da construção civil entre 2007 e 2013 e a aprovação da Política Nacional de Resíduos Sólidos n 12.305, de 2010, criou um novo marco no setor de resíduos de construção foi promovido, dando nova força à gestão e reciclagem de RCD.

Com a promulgação da Lei no 12.305, que institui a PNRS, Política Nacional de Resíduos Sólidos houve um aumento da quantidade de UREs (usinas de reciclagem de entulho), pois a lei exige que todos os municípios elaborem seu PGRS Plano de Gestão de Resíduos Sólidos.

Um levantamento de Miranda (2016) em parceria com a ABRECON (Associação Brasileira de Reciclagem de RCD) aponta o acentuado crescimento do número de Usinas de reciclagem no período 2007 a 2015. Mas este trabalho apresenta apenas 100 URES que responderam a pesquisa, e destas 54\% estão localizadas na região Sudeste e a maioria (83\%) são particulares.

A ABRELPE em 2015 estimou que existissem no Brasil 323 Unidades de Reciclagem de Entulho (URE) sendo a maioria ainda localizada na região sudeste.

Este dado está muito aquém do total de municípios brasileiros que são mais de 5500 municípios.

Um diagnóstico sobre Resíduos Sólidos Urbanos feito pela prefeitura de Campinas aponta que $64 \%$ dos RSU gerados no município é proveniente da indústria da construção.

Um diagnóstico elaborado por Pettito (2017) aponta que na Região Metropolitana de Campinas existiam 6 UREs sendo 4 privadas, 1 parceria publico/privada e uma municipal, hoje existe também mais uma URE em Valinhos que é particular. 
Dentro da RMC existem três consórcios formalizados entre municípios para parceria no tratamento dos RCD, porém apenas o consórcio CONSAB que envolve os municípios de Engenheiro Coelho, Arthur Nogueira, Cosmópolis, Holambra e Jaguariúna adquiriu um britador móvel que é utilizado pelos cinco municípios.

Existem também na RMC três aterros de inertes - em Indaiatuba, Paulínia e Campinas e em princípio estes aterros deveriam ter uma área de transbordo e triagem e manter estocados os resíduos inertes por período de tempo determinado, prevendo uma posterior reciclagem dos resíduos classe A.

Uma imagem do aterro de inertes de Campinas mostra que se recebe muito mais do que a capacidade de processamento da Unidade Recicladora.

\section{PRODUÇÃO DE AGREGADOS RECICLADOS}

O RCD que chega as Unidades recicladoras, na maioria das vezes não é entregue triado na origem, as caçambas de entulho trazem não só os resíduos classe A, que são passíveis de serem transformados em agregados, mas frequentemente estes vem misturados com resíduos classe B (com possibilidade de reciclagem em outra cadeia produção como madeira aço e vidro) e até mesmo com resíduos classe D.

Portanto é de fundamental importância que a triagem do RCD seja feita antes da produção do agregado reciclado ou da deposição em aterro de inertes. Essa triagem

pode ser manual, que demanda mais funcionários e não é tão eficiente como a mecânica, utilizando esteiras. A triagem mecânica também proporciona aos funcionários, melhor condição de trabalho.

Os materiais classe B são normalmente comercializados, a maioria das usinas processa a madeira para a geração de cavacos para queima em caldeiras. 
E os resíduos que não tem possibilidade de aproveitamento em outra cadeia produtiva são encaminhados para aterro sanitário.

As características dos agregados reciclados dependem do processo de produção na planta da unidade recicladora e existem diferenças significativas nas características de agregados produzidos em diferentes plantas.

Vários pesquisadores apontam que a fase de triagem é a que mais afeta a qualidade dos agregados reciclados, principalmente se forem produzidos para produção de concreto.

Neste sentido o melhor sistema de triagem deve separar o solo antes do processo de britagem por meio de peneiramento; este material pode ser usado para pavimentação, recuperação de áreas degradadas, e também para camadas de fechamento de aterro sanitário.

Mesmo após a remoção dos resíduos classe $\mathrm{B}$, a composição do resíduo classe A é bastante heterogênea, pois depende do tipo de obra e técnica construtiva empregada.

A Composição dos resíduos classe A foi estudada por diversos pesquisadores e essa variabilidade em sua composição pode ser observada na Tabela 1, onde por exemplo a $\%$ de concreto varia de $4,8 \%$ ate $42,9 \%$.

Tabela 1. Composição de Resíduos de Construção

\begin{tabular}{|c|c|c|c|c|c|}
\hline Material & $\begin{array}{c}\text { Pinto } \\
(1987 \\
)\end{array}$ & $\begin{array}{c}\text { Zorda } \\
\text { n e } \\
\text { Paulo } \\
\text { n } \\
(1997) \\
\left({ }^{* *}\right)\end{array}$ & $\begin{array}{c}\text { Maced } \\
\text { o et al. } \\
(2009) \\
\left({ }^{* *}\right)\end{array}$ & $\begin{array}{l}\text { CARNEIR } \\
\text { O et al. } \\
(2001)\end{array}$ & $\begin{array}{c}\text { Marque } \\
\text { s Neto } \\
(2003) \\
\left(^{*}\right)\end{array}$ \\
\hline $\begin{array}{l}\text { Argamass } \\
\text { a }\end{array}$ & $\begin{array}{c}64,4 \\
\%\end{array}$ & $37,6 \%$ & $26,5 \%$ & $53 \%$ & $8 \%$ \\
\hline
\end{tabular}




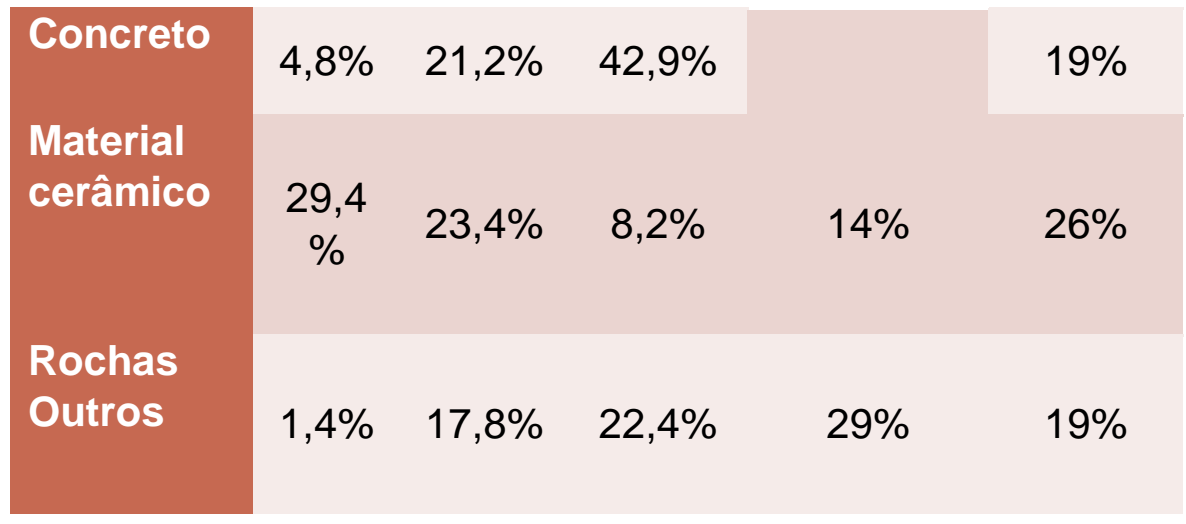

A estrutura de uma Usina de reciclagem após o processo de triagem é similar a de uma pedreira, com equipamentos de britagem e de classificação granulométrica que é composto por peneiras vibratórias.

\subsection{Tipos de agregados reciclados e sua aplicação}

A NBR 15116:2004 define as classes de agregados reciclados e suas características para aplicação como agregado para pavimentação ou para produção de concreto sem fins estruturais.

Para a pavimentação o agregado reciclado pode ser proveniente da britagem do resíduo classe A sem ressalvas (engloba solo - material cerâmico - concreto brita argamassa sem distinção).

Para produção de concreto sem fins estruturais a norma define a produção de 2 tipos de agregados reciclados Agregado Reciclado de Concreto (ARC) e Agregado Reciclado Misto (ARM).

O ARM - agregado de resíduo misto pode apresentar acima de 10\% de partículas constituídas por material cerâmico. 
O ARC - agregado de resíduo de concreto deve ter em sua composição no mínimo $90 \%$ de partículas que sejam constituídas de rocha e argamassa;

Qualquer destes dois tipos de agregado pode ser usado na produção de concreto sem fins estruturais em proporção de substituição do agregado natural de ate $100 \%$.

Os agregados reciclados podem ser utilizados em inúmeras aplicações, o desempenho dele depende da relação entre suas características e composição e a aplicação, por exemplo:

Solo:

- pavimentação;

- produção de tijolos cerâmicos e de solo cimento;

- camadas de fechamento de aterro;

Agregado com alto teor de material cerâmico:

- produção de tijolos cerâmicos;

- argamassa de assentamento;

- camadas de fechamento de aterro.

\section{Agregado com alto teor de material cimentício:}

- produção de concreto;

- concreto para blocos e pisos intertravados;

- argamassas.

Em outros países existem normas que especificam mais classes de agregados reciclados além de permitir, dentro de determinados limites, sua aplicação para 
produção de concreto para fins estruturais. A Tabela 2 apresenta algumas das normas, tipos de agregados e limites propostos para uso na produção de concreto.

Tabela 2. Normas que regulamentam a classe e a aplicação de agregados reciclados.

\begin{tabular}{|c|c|c|c|}
\hline País & Norma & $\begin{array}{l}\text { Classe de agregado } \\
\text { reciclado }\end{array}$ & $\begin{array}{l}\text { Limites para aplicação em } \\
\text { Concreto Armado }\end{array}$ \\
\hline $\begin{array}{l}\frac{\mathbb{T}}{\mathbb{L}} \\
\frac{\mathbb{N}}{\mathbb{E}} \\
\frac{\mathbb{U}}{\mathbb{L}}\end{array}$ & DIN 4226-100 & $\begin{array}{l}\text {-Agregado reciclado de } \\
\text { concreto; } \\
\text {-Agregado reciclado de } \\
\text { resíduos de demolição; } \\
\text {-Agregado reciclado de } \\
\text { alvenaria; } \\
\text {-Agregado reciclado } \\
\text { misto }\end{array}$ & $\begin{array}{l}\text { Os agregados reciclados de } \\
\text { concreto e de resíduos de } \\
\text { demolição podem ser usados } \\
\text { na produção de concreto } \\
\text { estrutural, os agregados de } \\
\text { alvenaria e os agregados } \\
\text { mistos podem ser usados } \\
\text { apenas em elementos não } \\
\text { estruturais. }\end{array}$ \\
\hline
\end{tabular}




\begin{tabular}{|c|c|c|c|}
\hline 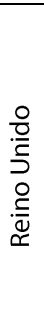 & $\begin{array}{l}\text { BS 8500:2 "Concrete - } \\
\text { Complementary British } \\
\text { Standard to BS EN 206- } \\
1 \text { - Part 2: Specification } \\
\text { for constituent } \\
\text { materials and concrete" } \\
(2002)\end{array}$ & $\begin{array}{l}\text { agregado reciclado de } \\
\text { concreto - } \mathrm{RCA} \\
\text { agregado reciclado - RA }\end{array}$ & $\begin{array}{l}\text { RCA - Pode ser usado em } \\
\text { estruturas com classe de } \\
\text { C40/50 e locais com maior } \\
\text { exposição. } \\
\text { RA (agregado reciclado): É } \\
\text { limitado ao uso em concretos } \\
\text { com resistência máxima da } \\
\text { classe de C16/20 e apenas em } \\
\text { locais com menor exposição. }\end{array}$ \\
\hline 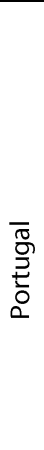 & $\begin{array}{l}\text { E } 471 \text { "Guideline for the } \\
\text { use of recycled coarse } \\
\text { aggregates in hydraulic } \\
\text { binders' concrete" } \\
\text { (2006) }\end{array}$ & $\begin{array}{l}\text { ARB1 -agregado reciclado } \\
\text { de concreto- pelo menos } \\
90 \% \text { concreto e rocha } \\
\text { ARB2 -agregado reciclado } \\
\text { de concreto - pelo menos } \\
70 \% \text { de concreto e rocha } \\
\text { ARC -mistura de concreto } \\
\text { e argamassa }\end{array}$ & $\begin{array}{l}\text { ARB1-Pode substituir até } 25 \% \\
\text { do agregado natural em } \\
\text { concreto de classe de } \\
\text { resistência de no máximo de } \\
\text { C40/50. } \\
\text { ARB2 -Pode substituir até } \\
20 \% \text { do agregado natural em } \\
\text { concreto de classe de } \\
\text { resistência de no máximo de } \\
\text { C35/45. } \\
\text { ARC - Pode ser usado apenas } \\
\text { em concreto não estrutural }\end{array}$ \\
\hline
\end{tabular}

Adaptado de Gonçalves e Brito (2010)

\section{UTILIZAÇÃO DO AGREGADO RECICLADO NA PRODUÇÃO DE CONCRETO}

As vendas de cimento no Brasil atingiram 53,8 milhões de toneladas em 2017, de acordo com o Sindicato Nacional da Indústria do Cimento (SNIC).

Essa quantidade de cimento pode gerar 179,5 milhões de metros cúbicos de concreto, como em cada metro cubico de concreto, 70\% é ocupado por agregado, aproximadamente 192 milhões de ton de agregados.

Quase 200 milhões de toneladas de agregados são necessários para produção de concretos e argamassas.

O Levantamento da ANEPAC mostra que em 2017 o consumo total de agregados foi aproximadamente 650 milhões de toneladas, aproximadamente um terço aplicado para produção de concreto. 
Devido a esta alta demanda de agregados, a produção de concreto passa a ser vista como um "LIXÃO" devido a grande possibilidade de incorporação de resíduos.

Só que não é tão simples, os materiais empregados como agregados influenciam diretamente nas características do concreto.

\subsection{Durabilidade do concreto}

As principais características do concreto que são afetadas pelo uso de agregado reciclado são a DURABILIDADE e o MÓDULO DE ELASTICIDADE.

Estas duas características são fundamentais quando nos referimos a concreto para fins estruturais porque as normas de concreto armado estabelecem diretrizes de vida útil mínima a ser atingida e de deformações máximas que a estrutura pode sofrer.

Quando se pensa em Durabilidade de estruturas de concreto armado deve-se avaliar a interação entre a estrutura de concreto, o ambiente e as condições de uso e operação.

Helene (1997 apud MEDEIROS; ANDRADE; HELENE, 2011) propôs a Representação gráfica do conceito de vida útil das estruturas. Ele dividiu a vida útil de uma estrutura, classificando-a quanto às manifestações apresentadas.

A vida útil de projeto ocorre enquanto os agentes agressivos estão penetrando no interior do concreto através de seus poros, sem causar danos à estrutura.

Já a vida útil de serviço se dá quando os efeitos dos agentes agressivos começam a serem manifestados, através de manchas, fissuras e destacamentos, momento em que a entrada de gases e fluídos interfere e começa a modificar a estrutura.

A vida última ou total corresponde ao tempo no qual ocorre a ruptura e colapso, total ou parcial, da estrutura. 
E por fim, a vida útil residual corresponde ao período de tempo no qual a estrutura não poderá desenvolver as suas funções (HELENE, 1997 apud MEDEIROS; ANDRADE; HELENE, 2011).

A durabilidade do concreto pode ser atribuída, principalmente à dificuldade de penetração dos agentes agressivos na rede de poros do concreto (OLLIVIER; VICHOT, 2014).

Atualmente, existe uma correlação entre permeabilidade e durabilidade e a porosidade do material. Ou seja, quanto mais poroso for o material, maior será a capacidade de entrada e saída de substâncias (permeabilidade) e, consequentemente, a estrutura terá uma perda em sua durabilidade, afetando diretamente a sua vida útil.

Para Mehta e Monteiro (2008), a porosidade do agregado é a característica que mais afeta o módulo de elasticidade do concreto.

Segundo Gidrão (2015), o primeiro fator que afeta o módulo de elasticidade é a relação água/cimento $(\mathrm{a} / \mathrm{c})$. Por exemplo, os concretos com menor relação a/c tendem a ser mais resistentes e rígidos. Quanto menor a quantidade de água utilizada, menor a porosidade do produto final. E, consequentemente, se terá um aumento da capacidade do material em restringir as deformações solicitantes no elemento.

O segundo fator que afeta o módulo de elasticidade, destacado por Gidrão (2015), refere-se às propriedades dos agregados graúdos utilizados para a mistura.

\subsection{A influência do agregado reciclado nas características do concreto}

Quando se fala na aplicação dos agregados reciclados em concreto com fins estruturais é fundamental ter conhecimento das características destes agregados e da influência do agregado reciclado nas características do concreto. 
O levantamento a seguir é parte de uma pesquisa elaborada pelos alunos Guilherme Sumitomo e Bruna Furian, que avaliou estatisticamente as características de agregado natural (NAT) e de mais três tipos de agregado reciclado, o agregado reciclado de concreto (ARCO), agregado reciclado cimentício (ARC) e agregado reciclado misto (ARM).

Este levantamento foi realizado coletando dados de agregados graúdos reciclados e naturais usados experimentalmente em pesquisas publicadas em artigos, teses e dissertações, tanto nacionais quanto internacionais. Foram selecionados e analisados 425 dados coletados em 75 trabalhos.

Os dados coletados para os agregados foram:

- Massa específica: foi utilizado dados retirados dos arquivos coletados, porém todos foram transformados na mesma unidade de medida $\left(\mathrm{kg} / \mathrm{dm}^{3}\right)$;

- Capacidade de absorção: foi coletada e adicionada na tabela com unidade de medida em porcentagem (\%);

- Tipo de agregado: os agregados foram classificados em 4 categorias: Agregado Natural (NAT), para todos que foram extraídos, ou seja, a forma tradicional de utilização; Agregado Reciclado de Concreto (ARCO), para todos os agregados que sofreram processo de reciclagem, porém nele só existe resíduo de concreto, betão e agregado natural; Agregado Reciclado Cinza (ARC), para aqueles agregados que foram reciclados e possuem quantidade de cimento Portland e rochas de no mínimo 90\%; e Agregado Reciclado Misto (ARM), para aqueles que possuem quantidade de cimento Portland e rochas com menos de $90 \%$.

Os dados do concreto no estado endurecido foram:

- Porcentagem de substituição do agregado graúdo ou miúdo;

- Relação água cimento; 
- Densidade;

- Resistência a compressão;

- Capacidade de absorção de água;

- Módulo de Elasticidade.

Os resultados deste levantamento e analise estatística apontam que a massa específica do agregado natural é maior que dos agregados reciclados (Figura 1).

Dentre os reciclados os ARCO tem valores mais próximos ao do agregado natural e o ARM é que apresenta maior variabilidade de resultados. Observa-se que para o agregado NAT possui uma pequena variação em seus valores. O agregado ARC apresenta uma grande variabilidade. O agregado ARCO mostra a menor variabilidade em relação aos outros agregados. O agregado ARM, tem a maior amplitude de valores.

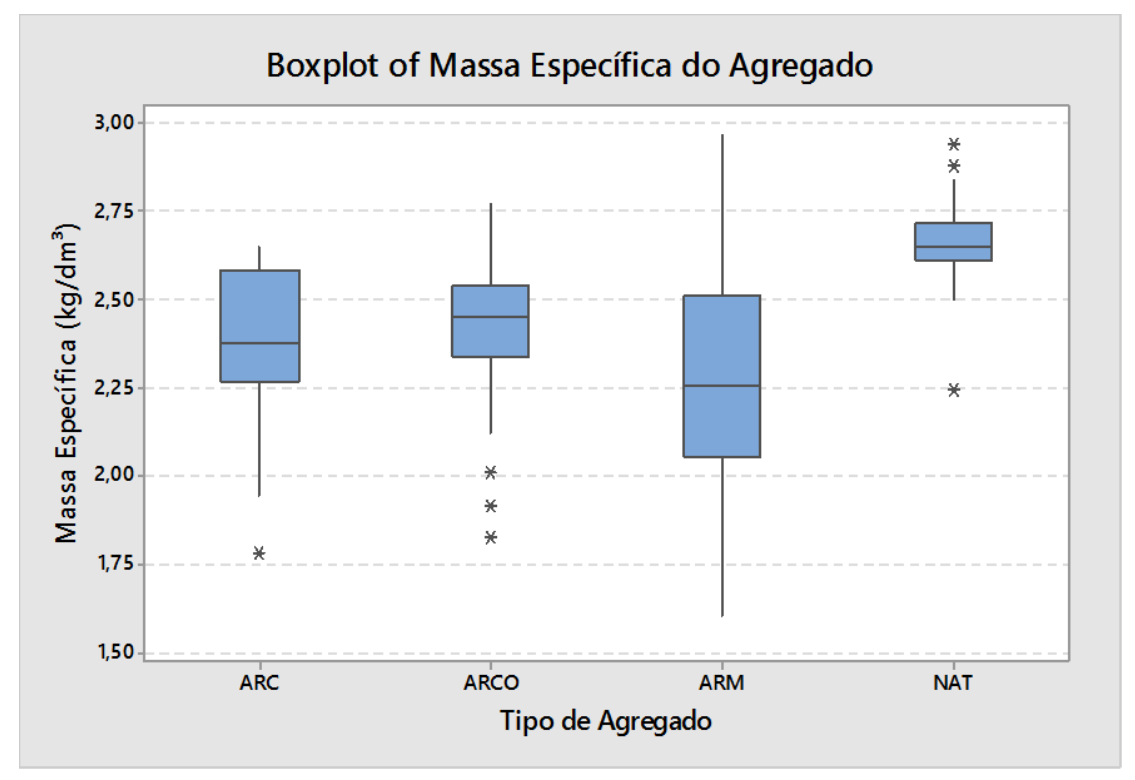

Figura 1-Boxplot de massa específica dos tipos de agregado pesquisado 
Com relação ao parâmetro capacidade de absorção de água, observou-se que o agregado NAT tem uma variação muito pequena e a menor capacidade de absorção, em torno de 1\%; o agregado ARCO tem a menor variabilidade dentre os reciclados e a menor capacidade de absorção; o agregado ARC apresenta uma variação grande e o agregado ARM contém valores mais altos e a maior variabilidade dos resultados (Figura 2).

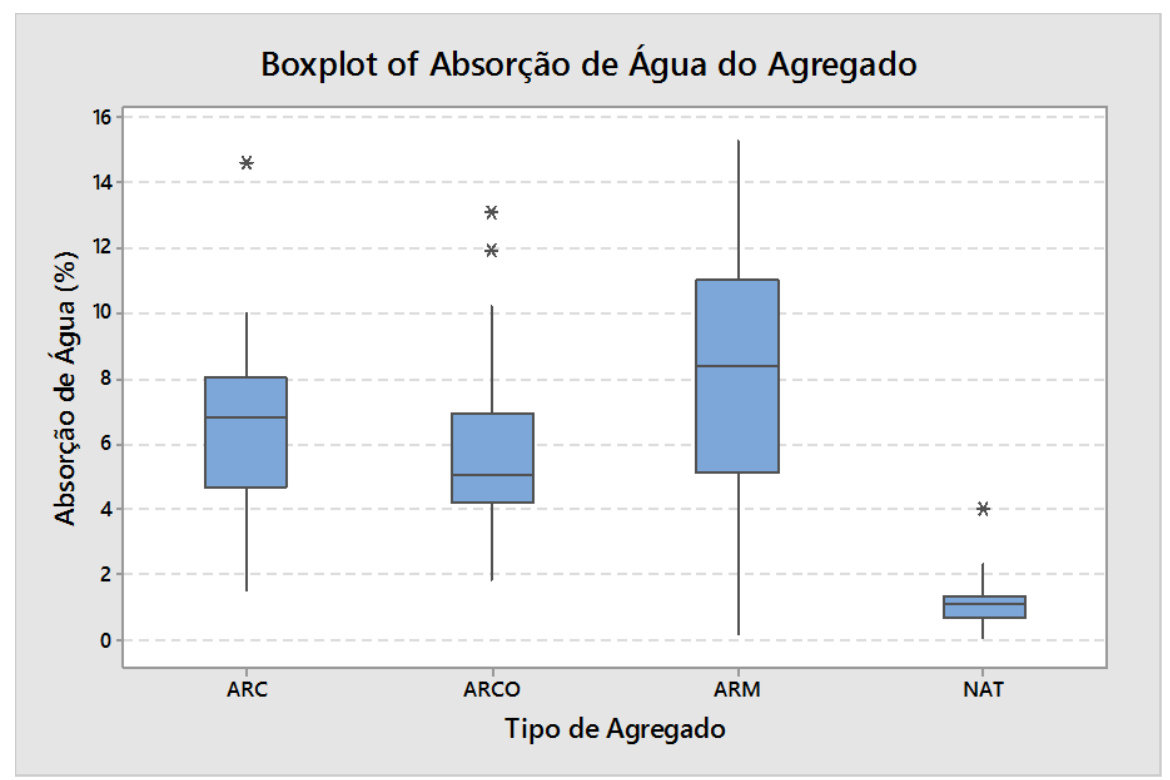

Figura 2 - Boxplot da absorção de água dos tipos de agregado pesquisado

Quando avaliarmos a relação entre capacidade de absorção de agua e massa específica, percebe-se uma tendência de ter um aumento da capacidade de absorção de água conforme diminui a massa específica do agregado. Os agregados reciclados apresentam também os maiores valores de capacidade de absorção de água, enquanto os NAT têm maiores valores de massa específica (Figura 3). 


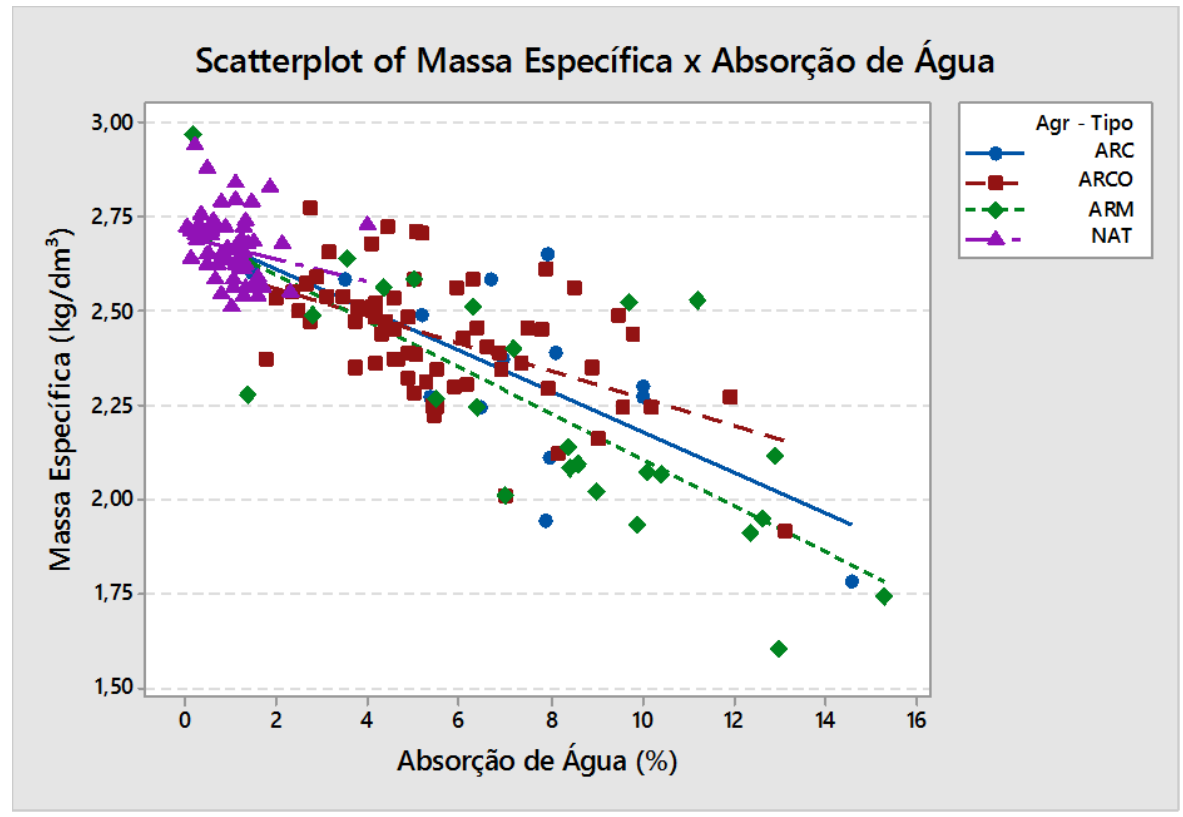

Figura3 - Distribuição de pontos massa específica X absorção de água separados em tipos de agregado

Com relação a Influência do agregado reciclado no concreto observou-se que a presença de agregados reciclados na composição do concreto influencia diretamente em suas propriedades físicas e mecânicas.

A massa específica do concreto sofre influência do agregado que o constitui, o concreto com agregado NAT apresenta maiores valores de massa específica. O concreto com ARCO apresenta menor variabilidade, tendo uma media próxima à do concreto com agregado NAT. Já o concreto com ARC, tem uma variação um pouco maior que o concreto com NAT e ARCO. O concreto com ARM obteve a maior variabilidade em seus valores, além do menor valor médio de massa específica (Figura 4). 


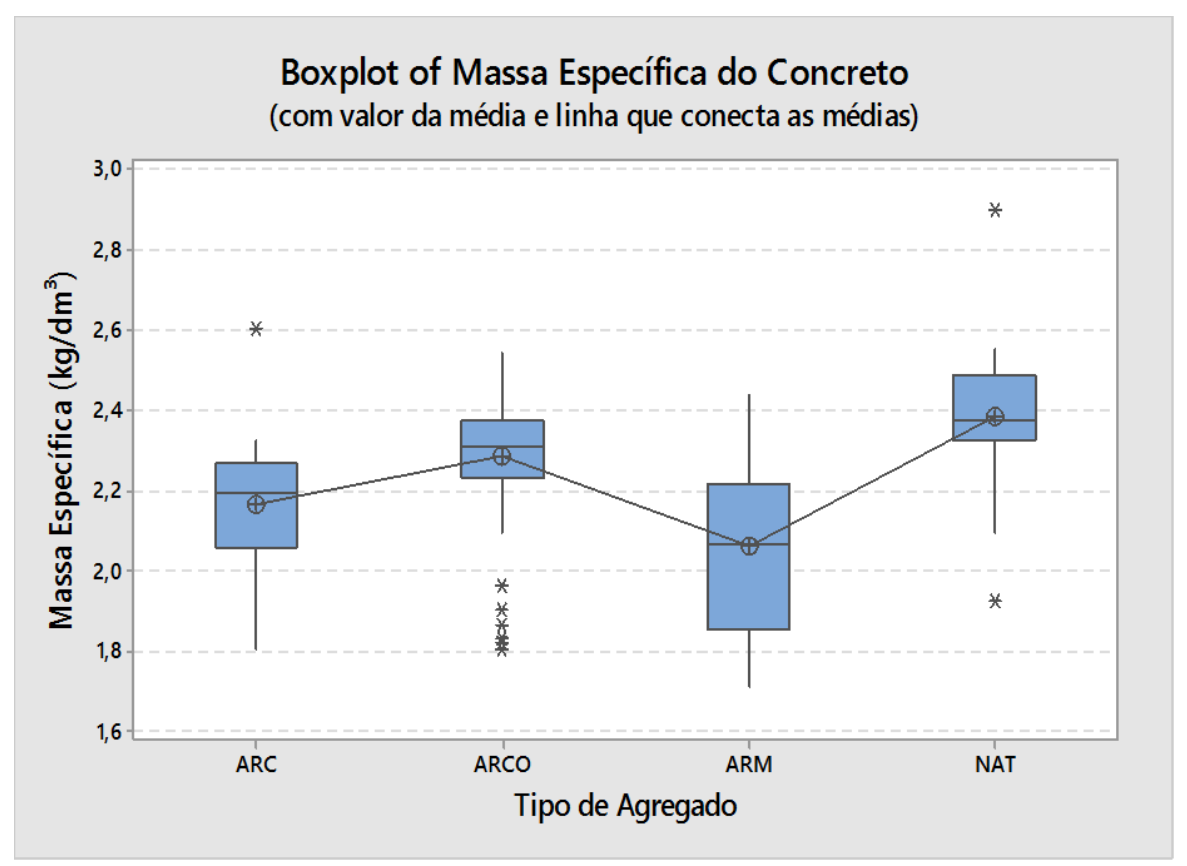

Figura 4 - Massa Específica do concreto

Com relação à capacidade de Absorção de água dos concretos, pode-se observar que os agregados reciclados alteram significativamente a capacidade de absorção de água do concreto, como mostra o gráfico, o concreto com ARCO é o que mais se aproxima do concreto com agregado natural (Figura 5).

O concreto com ARC é o que obteve os maiores valores de absorção, apesar do baixo desvio padrão. Já o concreto ARM, mostra a maior variabilidade de resultados. 


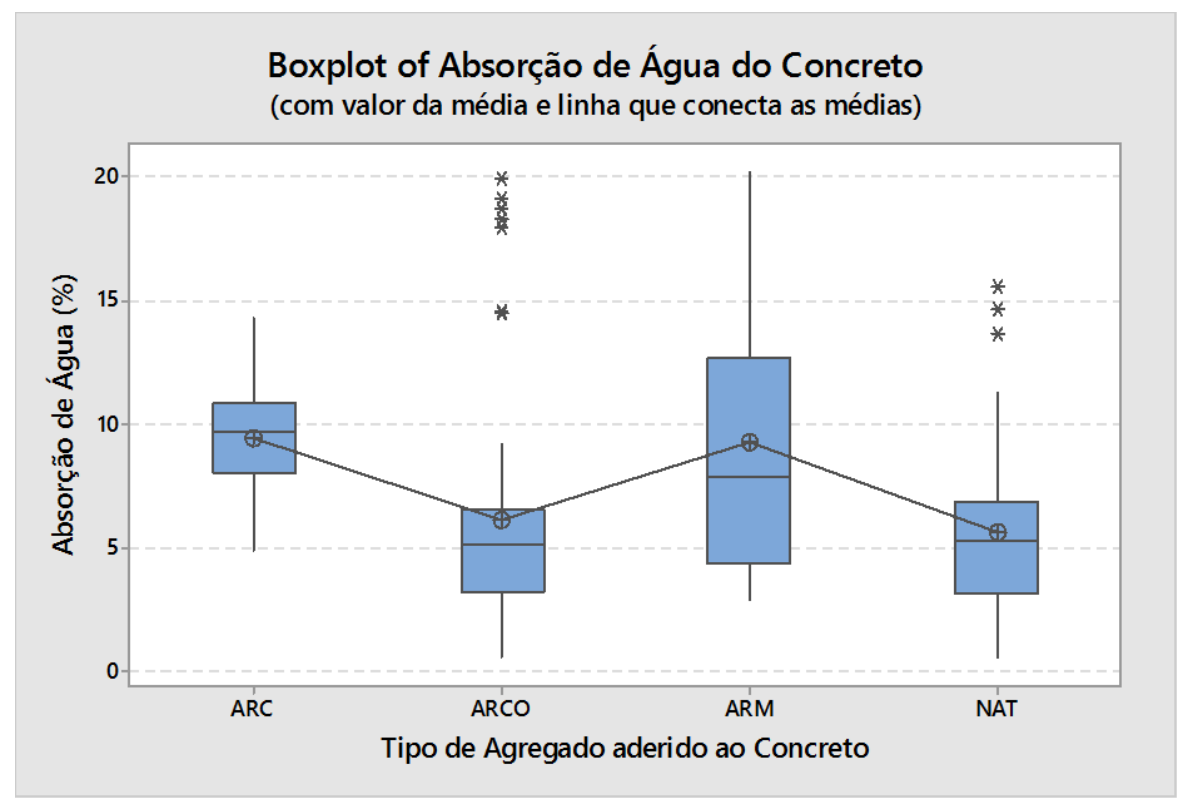

Figura 5 - Capacidade de absorção de água do concreto

Quando se analisa a capacidade de absorção de água em função do aumento da porcentagem de substituição do agregado NAT pelo agregado reciclado, observase que há um aumento da capacidade de absorção de água do concreto endurecido (Figura 6). 


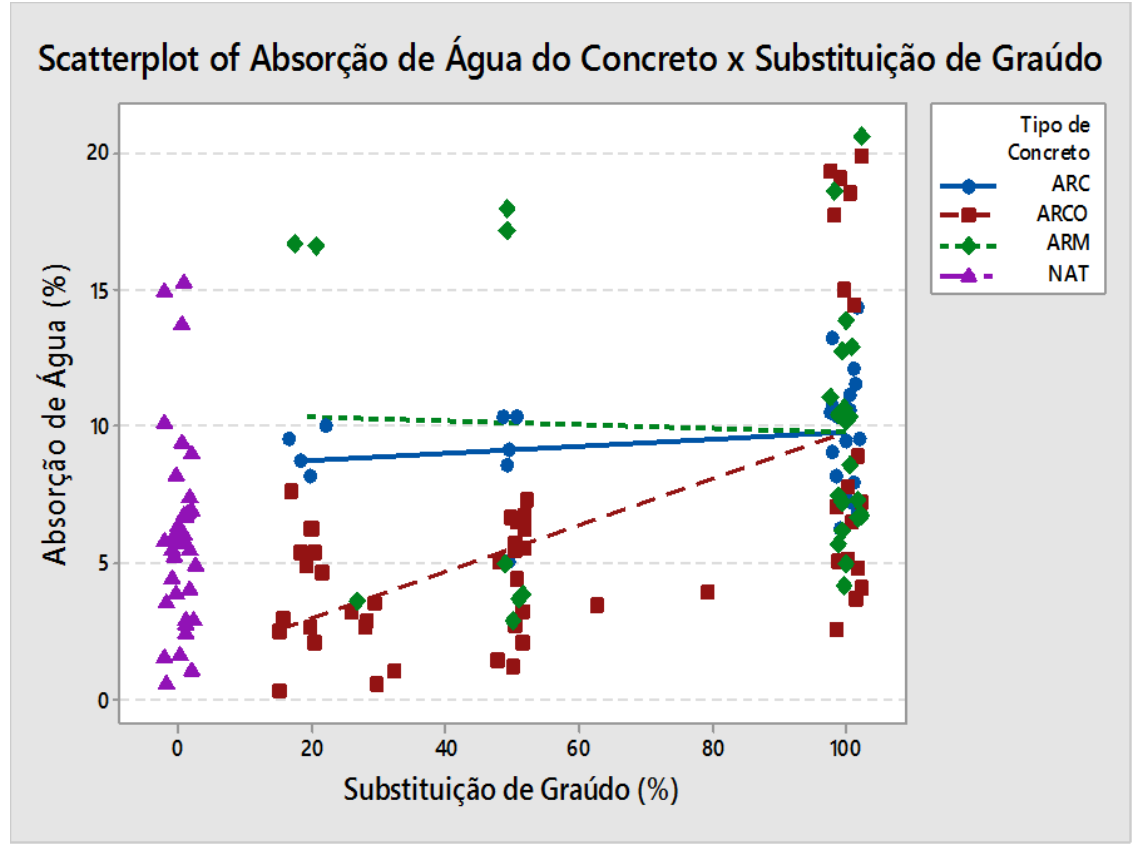

Figura 6 - Capacidade de absorção de água do concreto

O concreto com ARCO apresenta valores parecidos de absorção de água com o concreto com NAT para substituições de $50 \%$ ou inferiores.

No caso dos concretos com ARC e ARM, obtiveram uma reta pouco inclinada devido à pequena quantidade de dados presentes para substituição menor que $100 \%$.

Para a análise de resistência a compressão foram separados os dados de resistência aos 28 dias do concreto referência no intervalo de $35 \mathrm{MPa}$ a $45 \mathrm{MPa}$ (Figura 7).

Os concretos com agregados reciclados sofreram uma redução considerável na resistência à compressão em função do aumento da porcentagem de substituição de agregado natural pelo reciclado.

Dos três tipos, o concreto com ARCO apresentou uma perda de resistência a compressão menor e o concreto com ARM tem os menores valores. Apesar do 
concreto com ARC ter poucos dados, obteve valores dentro do intervalo e uma reta com a mesma inclinação que o concreto com ARM.

Observa-se também na mesma imagem que o número de dados abaixo do intervalo aumenta conforme aumenta a substituição de agregado graúdo, dando uma evidência de que, quando maior a substituição realizada, maiores as chances de o resultado final estar abaixo do intervalo.

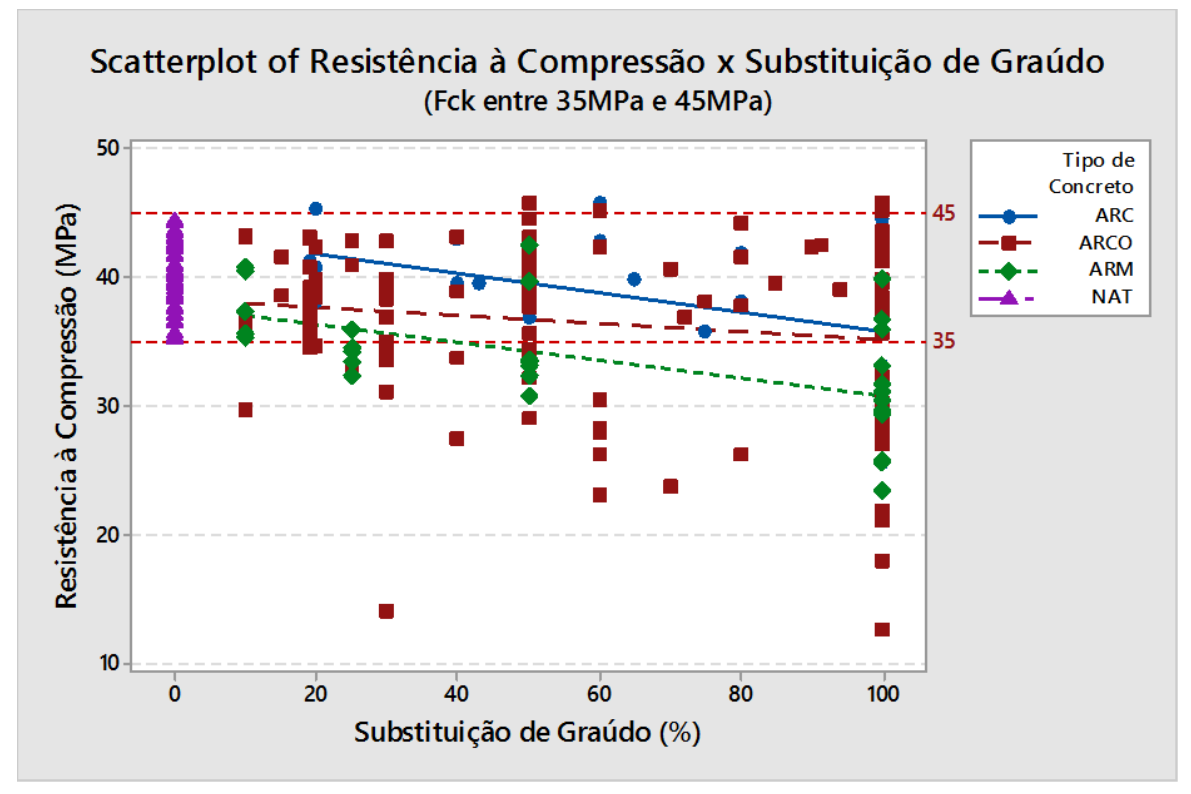

Figura 7 - Resistencia a Compressão axial em função da porcentagem de substituição

A análise do parâmetro módulo de elasticidade para os concretos de classe de resistência $40 \mathrm{MPa}$, aponta uma redução do módulo em função da porcentagem de substituição do agregado natural pelo reciclado (Figura 8).

Para concreto com ARC e ARCO, observa-se uma queda no módulo conforme aumenta a porcentagem de substituição com a mesma inclinação,

O concreto com agregado ARM, apresenta uma queda mais significativa em função da porcentagem de substituição. 


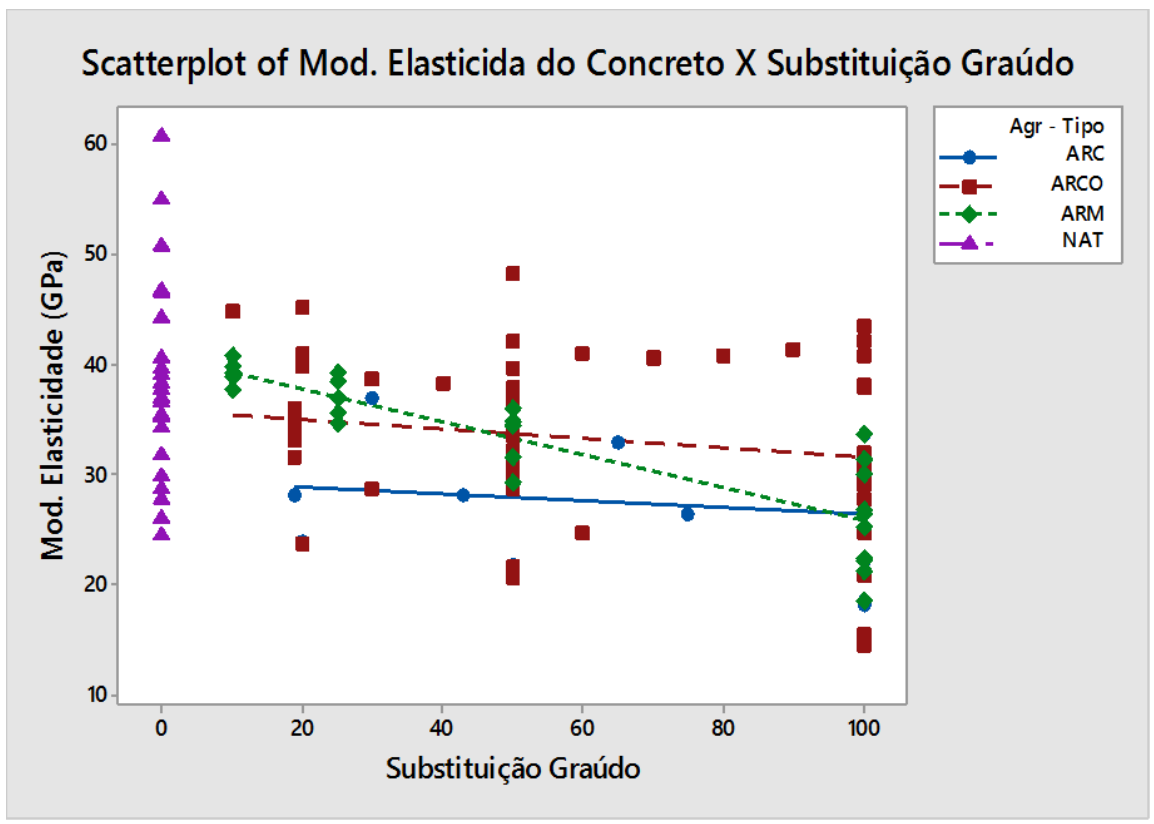

Figura 8 - Módulo de elasticidade x Substituição graúdo (40MPa)

Com relação a influência da porcentagem de substituição do agregado natural pelo reciclado que com o aumento de substituição do agregado natural por agregado reciclado ocorre:

Diminuição da densidade do concreto;

Aumento da absorção de água;

Variação do módulo de elasticidade conforme o tipo de agregado, apesar que todos possuem uma diminuição do mesmo;

Diminuição da resistência do concreto;

Em relação a influência do tipo de agregado reciclado observou-se que:

Os agregados com maior massa específica causam menor impacto nas características mecânicas do concreto, como evidenciado pelos resultados obtidos por concreto com ARCO. 
Agregados reciclados com maior capacidade de absorção de agua geram concretos mais porosos e com maior capacidade de absorção de água.

\subsection{Durabilidade do concreto}

A durabilidade não é um parâmetro mensurável, ela é avaliada em função de medições indiretas da capacidade de transporte dos íons para o interior do concreto.

O tempo necessário para que os íons adentrem o interior do concreto depende primeiramente da concentração externa de íons e da microestrutura do concreto.

A Capacidade de absorção de água por imersão e por capilaridade são os ensaios mais básicos que mostram o transporte de fluidos no concreto, os ensaios são normatizados conforme NBR 9778:2009 para a absorção por imersão e NBR 9779:2013 para absorção por capilaridade.

A literatura apresenta diversos métodos desenvolvidos para determinar a permeabilidade ao ar e a água, a NBR 10786 é um método para determinação da permeabilidade a água sob pressão de $4 \mathrm{Mpa}$, tem como inconveniente o tempo de duração do ensaio de 500horas.

Um método qualitativo é a utilização de equipamentos como o Porosiscope, da James Instrument que faz determinação da permeabilidade tanto ao ar como a água e tanto em profundidade como superficial. É um equipamento para medição "in loco". E como resultado tem-se a qualidade do concreto em função do tempo para percolação do ar ou da agua no concreto.

A carbonatação do concreto é um processo físico-químico, que consiste no avanço do dióxido de carbono $(\mathrm{CO} 2)$ da atmosfera em direção ao interior do concreto, através dos poros. 
A Equação 1 apresenta de forma simplificada que o dióxido de carbono reage com hidróxidos alcalinos dissolvidos, formando carbonatos. Este processo faz com que o valor do pH da solução aquosa seja alterado, de 12,5 para um pH em torno de 9.

$$
\mathrm{CO} 2+\mathrm{Ca}(\mathrm{OH}) 2>\mathrm{CaCO} 3+\mathrm{H} 2
$$

O ensaio de Carbonatação mostra a profundidade da camada de concreto que tem seu pH reduzido em função - o processo de carbonatação. Essa identificação é feita por um indicador de $\mathrm{pH}$ a fenolftaleína.

Este é um teste utilizado para avaliar a resistência do concreto contra a penetração de cloretos, realizados segundo procedimentos descritos na AASHTO T259.

O ensaio de penetração de íons cloretos determina, em função da alteração de coloração que uma solução de nitrato de prata aspergida ao concreto, sofre quando em contato com ions cloreto.

A migração de íons cloreto através do concreto é um processo lento, e então pesquisadores buscaram uma maneira de acelerar essa migração. Quando uma tensão elétrica é aplicada em uma amostra de concreto, aumenta-se e acelera-se a velocidade em que os cloretos migram no concreto (IFFAT et al 2014).

O método mais comum utilizado para determinar a profundidade de penetração e íons cloreto é pela ASTM C1202/05 (REAL et al 2015).

Medeiros Junior (2014) apontou que tanto a absorção, quanto a difusão, devem ser consideradas nas propostas de modelagìns do ingresso dos cloretos. Porém, a maioria dos modelos apenas considera um mecanismo, e na maioria dos casos a difusão é o único parâmetro levado em consideração. Medeiros Junior (2014) ainda afirmou que na segunda lei de Fick apenas a difusão é modelada. 
As amostras são saturadas e colocadas entre duas células acrílicas, sendo que cada uma delas é preenchida com uma solução, sendo a primeira célula preenchida com uma solução de hidróxido de sódio $(\mathrm{NaOH})$ de concentração de $0,3 \mathrm{~N}$ e a outra célula preenchida com uma solução de cloreto de sódio $(\mathrm{NaCl})$. Os dois pólos das células são conectados a uma fonte de tensão de $60 \mathrm{~V}$, e o ensaio tem duração de aproximadamente $6 \mathrm{~h}$ (MEDEIROS et al 2012).

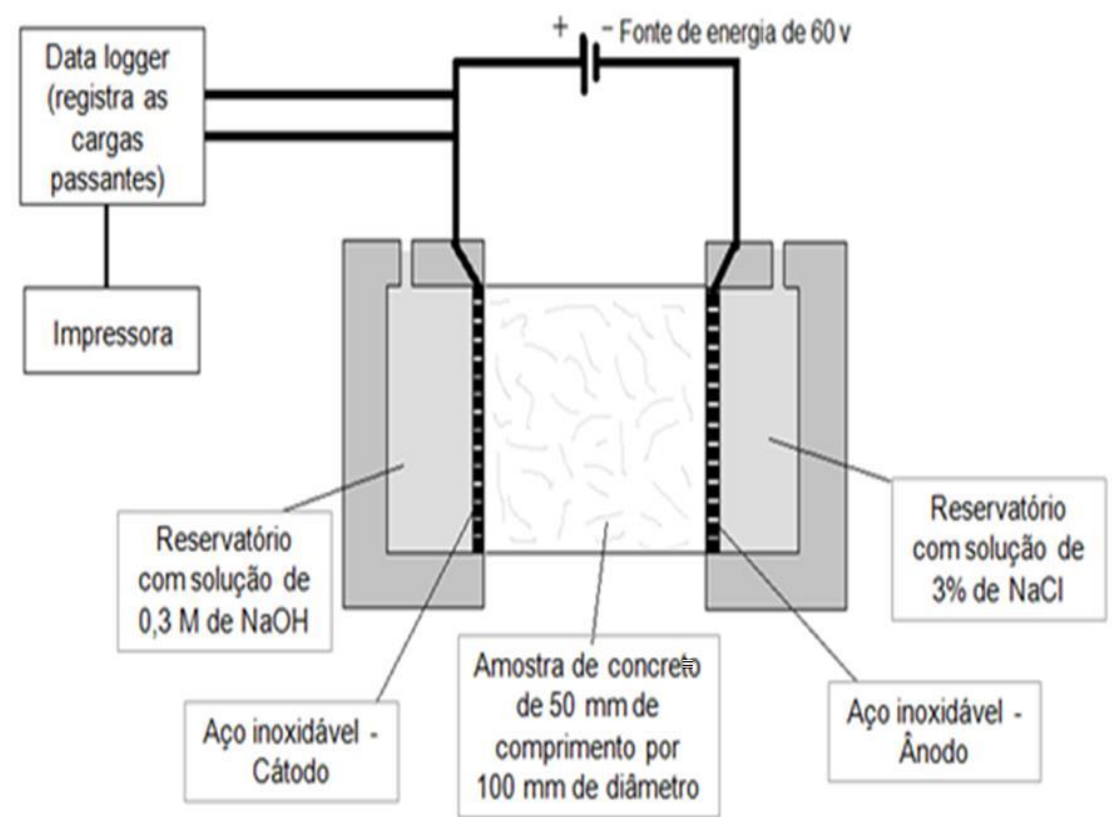

Figura 9. Ensaio de difusão de ions cloreto

\section{REFERÊNCIAS}

ASSOCIAÇÃO BRASILEIRA DAS EMPRESAS DE LIMPEZA PÚBLICA E RESÍDUOS ESPECIAIS. Panorama dos Resíduos Sólidos no Brasil. 2015.

AMERICAN SOCIETY FOR TESTING AND MATERIALS. ASTM C 1202-05:

Standard test method for electrical indicatio^ of concrete abÛlity to resist Ôhloride ion penetration. Philadelphia, 2005. 
AMORIM, A. A. Durabilidade das estruturas de concreto armado aparentes. 2010. $74 \mathrm{f}$. Monografia (Especialista em Construção civil) - Universidade Federal de Minas Gerais, Belo Horizonte, 2010.

ANDRADE, J. J. O. Durabilidade das estruturas de concreto armado: análise das manifestações patológicas nas estruturas no estado de Pernambuco. 1997. $151 \mathrm{f}$. Dissertação (Mestrado em Engenharia) - Universidade Federal do Rio Grande do Sul, Porto Alegre, 1997.

GIDRÃO, G. M. S. Propriedades dinâmicas do concreto e relações com sua microestrutura. 2015. 132 f. Dissertação (Mestrado em Engenharia Civil) Universidade Estadual de São Paulo, São Carlos, 2015.

IFFAT, S.; EMON, M. A. B.; AHMAD, S. I. An experiment on durability test (RCPT) of concrete according to ASTM Standard Method Using Low-Cost Equipments. Advanced Materials Research, Suíça, v. 974, p. 335 - 340, Jun. 2014. Disponível em: https://scholar.google.com/citations?user=-uHpmLYAAAAJ\&hl=en.

JOHN, V. M.; AGOPYAN, V. Reciclagem de resíduos da construção. Seminário Reciclagem de Resíduos Sólidos Domiciliares. Secretária do Estado do Meio Ambiente. 2013.

MEDEIROS, M. H. F., ANDRADE, J. J. O., HELENE, P. Durabilidade e Vida útil das estruturas de concreto. In: ISAIA, G. C. Concreto: Ciência e Tecnologia. São Paulo, 2011. v. 1.

MEDEIROS, M. H. F. et al. Ensaio de migração de cloretos para concreto: influência do número de fatias extraídas. Rem: Revista Escola de Minas, Ouro Preto, v. 65, p. 475-481, dez. 2012.

MEDEIROS JUNIOR, R. A. Estudo da resistividade do concreto para proposta de modelagem de vida útil - corrosão das armaduras devido a penetração de íons cloreto. 2011. $244 \mathrm{f}$. Tese (Doutorado em Engenharia de Infraestrutura de Aeronáutica) - Instituto Tecnológico de Aeronáutica, São José dos Campos, São Paulo, 2011.

MEHTA P. M., MONTEIRO P. M. J. Concreto: estrutura, propriedades e materiais. São Paulo: PINI, 2008.

REAL, L. V.; OLIVEIRA, D. R. B.; MEDEIROS, M. H. F. Método colorimétrico por aspersão de nitrato de prata para avaliação da penetração de cloretos em concreto: estado da arte. Revista ALCONPAT, México, v. 5, n. 2, p. 149 - 159, maio, 2015. 
GONÇALVES, P.; BRITO, J. de Recycled aggregate concrete (RAC) - Comparative Analysis of existing specifications. Magazine of Concrete Research, Reino Unido, v. 62, p. 339 - 346, Jun. 2009. Disponível em:

$<$ https://www.researchgate.net/publication/250072777_Recycled_aggregate_concret e_RAC_-_Comparative_analysis_of_existing_specifications $>$. Acesso em: 20 jan. 2017.

MEDEIROS, M. H. F.; ANDRADE, J. J. O.; HELENE, P. Durabilidade e Vida útil das estruturas de concreto. In: ISAIA, G. C. Concreto: Ciência e Tecnologia. São Paulo, 2011. v. 1.

MIRANDA, L. F. R. et al. Panorama atual do setor de reciclagem de resíduos de construção e demolição no Brasil. In: ENCONTRO NACIONAL DE TECNOLOGIA DO AMBIENTE CONSTRUÍDO. 16., São Paulo, 21 a 23 de Setembro de 2016.

INSTITUTO DE PESQUISA ECONÔMICA APLICADA. Diagnóstico dos Resíduos Sólidos da Construção Civil, 2012.

Prefeitura Municipal de Campinas - Plano de Gestão Integrada de Resíduos Sólidos - PGIRS Munícipio De Campinas

\section{OLIVEIRA, L. C. B. Análise da Permeabilidade e da Colmatação em Concretos} Permeáveis produzidos com Agregado Reciclado de Concreto. Dissertação de Mestrado em Sistemas de Infraestrutura Urbana, 2017.

PETTITO, R. M. Analise da viabilidade da aplicação de resíduos de construção da Região Metropolitana de Campinas em argamassa de uso geral por método multicritérios. Dissertação (Mestrado), PUC Campinas, 2017.

RIZZO, Giovanna Falzetta. Durabilidade de concretos com agregados reciclados. 2018. Dissertação de Mestrado (Mestrado em Sistemas de Infraestrutura Urbana) Programa de Pós-graduação em Sistemas de Infraestrutura Urbana, Pontifícia Universidade Católica de Campinas, Campinas, 2018. 


\section{A INFLUÊNCIA DO PATRIMÔNIO CULTURAL MUSEALIZADO NA PERCEPÇÃO DAS CIDADES}

Celso Fernando Barroso Lima ${ }^{1}$

Sávio Tadeu Guimarães ${ }^{2}$

\section{RESUMO}

Para Max Weber a principal característica da sociedade moderna é o processo de racionalização perpetrado no mundo ocidental desde o fim da Idade Média (WEBER, 2005). Assim a epistemologia racional crítica, a universalidade, o ideal iluminista de progresso, a diferenciação estrutural, a integração funcional e o determinismo são elementos estruturantes desse período (HABERMAS, 1987). Com isso a modernização conduziu a emergência de novas identidades sociais, e o acelerar dos processos sociais e económicos, associados a fenômenos como o desenvolvimento dos meios de comunicação e de transporte de massas, juntamente com o crescimento das cidades, o êxodo rural e os grandes fluxos populacionais transnacionais, conduzindo o mundo a um redimensionamento no espaço e no tempo (ANICO, 2005). Assim o homem moderno careceu de novas estruturas de cidades que suprissem suas demandas. Paralelo a esses processos houve também a emancipação do homem de fatores externos como a religião. Assim esse ideal de liberdade é materializado no Estado Moderno conforme diz Shinn: O componente emancipatório da modernização foi encarnado no Estado-nação, o qual introduziu os princípios de cidadania, dever, burocracia, direitos e responsabilidades institucionais e, não menos importante, de fronteiras. Estas últimas são as do Estadonação, construídas em torno da linguagem, da geografia, da história, da cultura e da política (SHINN, 2008, p. 46). Esse processo emancipatório levou a configuração de uma sociedade pautada no individualismo, na racionalização e na diferenciação de classe (ASCHER, 2010). O ideal de progresso, assentado nos valores iluministas e tecnicistas conduziram a sociedade tradicional para uma crise, já que, os valores históricos e afetivos não são condicionantes importantes para a organização social moderna (GIDDENS, 2003). Essa discussão tem início com o reconhecimento de que, em uma sociedade tradicional, a identidade social dos indivíduos é limitada pela própria tradição, pelo parentesco e pela limitação geográfica em que a pessoa se encontra. A modernidade, leva ao nascimento de uma ordem pós-tradicional, onde

\footnotetext{
${ }^{1}$ Centro Universitário de Brasília / celsolimaunb@gmail.com

${ }^{2}$ Centro Universitário de Brasília / savio.guimaraes@ceub.edu.br
} 
os valores não são fixados segundo a tradição (GIDDENS, 2003). O centro da vida humana passou a girar em torno das cidades reorganizada em torno da indústria, onde houve o alargamento dos condicionantes temporais e espaciais, que produziu uma diferenciação social cada vez mais complexa (ASCHER 2010). Desta maneira a ideia de progresso vai ser o norte das teorias sobre urbanismo e a organização dos espaços habitados pelo homem no século XIX, as teorias advindas dessa ciência é pautada pelas ideias de positivistas de racionalidade e progresso da sociedade industrial (BENÉVOLO, 1983). Ao romper com as práticas e preceitos preestabelecidos, a sociedade moderna enfatiza o cultivo das potencialidades individuais, oferecendo ao indivíduo o fim de sua unidade ontológica. Desse modo a racionalidade moderna alienou o individuo em relação ao seu passado histórico e ao seu meio, produzindo novas configurações do espaço com a consolidação do regime capitalista no ocidente e o aumento da população urbana (GUIMARÃES, 2003). Por causa disso os espaços assentados na ideia de racionalidade são muitas vezes locais de impessoalidade, em que os indivíduos não têm nenhuma relação afetiva e emocional, a cidade da era industrial tornou-se o exemplo de espaços da sociedade póstradicional, local que inviabiliza em muitos casos a formação das identidades coletivas. Destarte na modernidade, o "eu" torna-se, cada vez mais, um projeto livre sempre em construção, pois já não existe mais a referência da tradição, descortina-se, para o indivíduo, um mundo de diversidade, de possibilidades abertas, de escolhas. O indivíduo passa a ser responsável por si mesmo e o planejamento estratégico da vida assume especial importância (ANICO, 2005). Logo, dento desse contexto a cidade moderna, fruto da crença cartesiana de o homem ter a possibilidade de corrigir os defeitos do ambiente com uma ação calculada em busca de uma teleologia tecnicista. As tentativas de corrigir esses problemas levam a inúmeras reformas setoriais e intervenções em vários núcleos urbanos como em Paris com o barão Haussmann, ou a ideia de uma cidade ideal, utópica para a nova realidade que se descortinava, como a cidade Linear de Arturo, ou a cidade jardim de Ebenezer Howard. Com isso as ideias urbanísticas eram orientadas pelo sentido de desenvolvimento da ciência e da técnica, higienização, salubridade, ou soluções de mobilidade, etc. A morfologia resultante para essas propostas levaram em muitos casos ao sacrifício da escala humana, produzindo vazios impessoais, monótonos. $\mathrm{O}$ auge dessas linhas de pensamento urbanístico é o IV Congresso de Arquitetura Moderna (CIAM) em Atenas no ano de 1933, a cidade aqui é zoneada, aparece a tipologia de habitação em massa, a destruição do quarteirão e da rua como local de permanência. Essa racionalidade que foi o "fio condutor" da morfologia urbana moderna entrou em crise nos anos 60, sobretudo após os estudos dos pensadores franceses ligados ao desconstrucionismo. Paralelamente a esse fenômeno houve o surgimento da cultural de massa, as cidades globais e a formação das megalópoles. Nesse contexto nascem novos valores e relação sociais (LASH; URRY, 1994), que ditam o ritmo assentados em um espaço global cada vez mais fluido (ROBINS, 
1999), levando a crise das metanarrativas e os surgimentos da pós-modernidade (HARVEY, 1989), a razão não dita mais os parâmetros da epistemologia pósmoderna, e assim a pós-modernidade é vista como um jogo de linguagem (LYOTARD, 1986) e a instauração de uma cultura liquida (BAUMAN, 2001) e híbrida (CANCLINI, 2003) referenciadas pela globalização. Diante desse quadro o sentimento de pertença espacial e cultural dos indivíduos dilui-se, tornando-se cada vez mais vago os laços sociais, possibilitando o crescimento nas cidades contemporâneas dos chamados não lugares (AUGÉ, 1992), locais de passagem, em que o individuo não cria uma relação afetiva com o espaço. Essa situação dificulta a criação de identidade no homem pós-moderno, instaurando, pois uma crise de identidade, logo é necessário criar novos mecanismo de identificação para o homem contemporâneo, habitante das grandes megalópoles, de cidades globais, que vê o mundo não mais pela ótica da racionalidade moderna, posta em xeque nos anos 60 . Assim a necessidade de um revisionismo crítico em torno das propostas urbanísticas modernas vai começar a nascer, tendo como pauta, principalmente a desvalorização da escala humana no urbanismo expresso no IV CIAM. A cidade dentro desse contexto já não pode ser pensada sem levar em conta a experiência do individuo, a imagem que ele forma sobre o meio urbano, e com isso a memória e o patrimônio vão se tornar vetores que ajudam nas interações sociais e que agora são elementos importantes no que tange as intervenções e renovações das teorias urbanas pós anos 60, sobretudo nos estudos pioneiros de Jane Jacobs, Kevin Lynch e Gordon Cullen e a valorização do patrimônio expresso na Carta de Veneza de 1964. Com isso a construção de novos referenciais simbólicos pautados na memória e no patrimônio cultura são fatores não negligenciáveis para a cidade atual. $\mathrm{O}$ passado ajuda a conferir sentido para vivência do tempo e do espaço presente. Assim a criação de lugares de memórias como os museus são importantes diante do cenário pósmodernos, pois esses espaços ajudam a conferir o sentido e novas sensibilidades, o sentido de coesão e coerência dentro de um grupo. E dessa forma o patrimônio é visto como a materialização da memória coletiva assegurando a identidade e conferindo o processo de formação da cidadania. Assim é necessário cada vez mais importante preservar experiência humana materializada no patrimônio, em espaços públicos que se destinam a tal fim, afim de que a partir desse patrimônio o homem contemporâneo possa construir uma relação afetiva com o meio em o mesmo está inserido. Portanto, perante a crise de identidade causada pelos fluxos imigratórios, o surgimento dos grandes centros urbanos, compreensão do mundo com o desenvolvimento dos meios de transporte e de comunicação, fizeram que as cidades modernas desvalorizassem o sentido humano em suas estruturas físicas e morfológicas, diluindo com isso, dimensão humana em prol da técnica, causando uma ausência de alteridade entre as pessoas e as cidades, que elas vivem, pois já não reconhecem esses espaços como um local de pertencimento. Essa pesquisa tem como objetivo analisar em que medida o patrimônio cultural musealizado influenciam na 
formação da percepção das cidades, possibilitando um enriquecimento da experiência humana com o espaço urbano. E como objetivos específicos estudar o conceito de percepção, conceituar museus e patrimônio, analisar estudos de casos de museus atuais e sua relação com o urbanismo e as cidades, investigar a simbiose entre patrimônio museológico, ou seja, os acervos dos museus, o prédio, e as cidades. A abordagem realizada foi qualitativa, pois foram realizadas leituras de textos e trabalhos acadêmicos, com a intenção de obter dados mais objetivos, que posteriormente esses dados foram interpretados com base em diversas referencias teóricas do campo das da Museologia, arquitetura, Urbanismo, Patrimônio e das Ciências Sociais. Diante da diluição da percepção do tempo e do espaço do homem contemporâneo os museus como locais de guarda do patrimônio cultural e histórico de uma comunidade, pode ser um espaço propício para um fortalecimento da coesão social dos habitantes com os espaços urbanos. "A experiência humana é guardada na memória, que apesar de ser um fenômeno individual é estruturada por referências coletivas" (POLLACK, 1992, p. 2), "cheia de flutuações necessita, pois ser materializada em marcos" (POLLACK, 1992, p. 2). Esses marcos são os patrimônios, ou seja, conjunto de bens com representatividade e expressão cultural. Pelegrini em seus estudos sobre patrimônio e memória diz: Assim, podemos inferir que não somente os objetos ou as coisas, mas suas representações imagéticas e simbólicas circulam nas entranhas das memórias dos sujeitos sociais, em meio a sentimentos e vivências que resistem ao ocaso e se mantém devotadas a sustentar vínculos com os seus lugares de pertencimento, historicamente construídos. Essa articulação se dá, pois os objetos, sons ou aromas dinamizam a memória coletiva ou individual e constituem manifestações da materialidade da cultura de um grupo social, desencadeando tensões entre as reminiscências e o esquecimento, numa busca constante de fortalecimento de seus elos com o seu lugar de pertencimento (PELEGRINI, 2007, p. 91). Dessa forma a percepção das cidades varia de acordo com intensidade da experiência individual com o espaço urbano. Nesse sentido os museus são relevantes para o urbanismo contemporâneo, ajudando a criar a priori, com ativação da memória, através dos patrimônios ali inseridos, um sentimento que leva a construção do sentimento de pertencimento da pessoa em relação aquele ambiente, e com isso contribuindo para o fortalecimento das relações humanas, outrora perdido diante do crescimento das cidades, dos fluxos imigratórios atuais, ou mesmo diante das propostas racionais do urbanismo moderno. Anico também corrobora essa ideia sobre o patrimônio como um elemento que ajuda na construção de representações: Património e museus desempenham um papel importante no que concerne quer à criação de consciências pessoais, quer no que diz respeito à construção e representação de identidades locais, regionais ou nacionais, em virtude do seu posicionamento enquanto instrumentos pedagógicos e ideológicos. Simultaneamente agentes e produtos da mudança política, social e cultural, os museus e sítios patrimoniais têm vindo a ser crescentemente problematizados como 
terrenos contestados, onde se debatem questões relacionadas com o que se entende por cultura, com a propriedade cultural, com as modalidades de representação ou, ainda, com as questões de poder associadas a essas representações (ANICO, 2005, p. 83). Portanto, a memória e o patrimônio, e não somente os estímulos físicos são responsáveis para despertar sentidos que criam imagens em uma cidade, os pontos focais levantados por Lynch, dependem não somente de sua estrutura física, mas também de seu significado como testemunha, patrimônio, ou seja, objetos que adquirem um valor único e de durabilidade representativa simbólica/material, que de acordo com sua particularidade significativa forma de expressão cultural de um povo. Para uma comunidade, somente depois de tal referência, um objeto torna-se um ponto focal, por isso a importância dos museus para as cidades, visto que, os museus são: Instituições sem fins lucrativos que conservam, investigam, comunicam, interpretam e expõem, para fins de preservação, estudo, pesquisa, educação, contemplação e turismo, conjuntos e coleções de valor histórico, artístico, científico, técnico ou de qualquer outra natureza cultural, abertas ao público, a serviço da sociedade e de seu desenvolvimento. (BRASIL, 2009). Assim os museus nas cidades atuais são espaços mediadores de relações, e atuam no sentido afetivo para os moradores desses ambientes e no fortalecimento dos vínculos sociais e identitários. Os museus como locais de guarda do acervo cultural e histórico de uma comunidade, pode ser um espaço propício para ajudar as correntes urbanísticas contemporâneas, uma vez que, as ações museológicas desempenhadas pelos museus têm como objetivos a divulgação do ser acervo através de diferentes atividades como a preservação, a exposição, e a pesquisa realizadas em seus acervos, os bens culturais ali preservados. Os acervos museológicos ajudam na materialização da memória. Assim diz Halbawchs: Fazemos apelo aos testemunhos para fortalecer a memória, mas também para completar, o que sabemos de um evento, do qual já estamos informados de alguma forma, embora muitas circunstâncias nos permaneçam obscuras (HALBAWCHS, 2004, p. 25). Diante disso os acervos museológicos ajudam a vencer a barreira do tempo e do espaço, contribuindo com a materialização da memoria coletiva (PELEGRINI, 2006), e assim essa pesquisa conclui que os ajudariam a formar o senso de comunidade, identidade, e conexão entre as pessoas, orientando suas ações e sentimentos diante da realidade, moldando os laços comunitários. Nesse sentido os acervos inseridos dentro dos museus são relevantes para o urbanismo contemporâneo, ajudando a criar a priori, com ativação da memória, um sentimento que leva a construção do sentimento de pertencimento da pessoa em relação aquele ambiente. Com isso contribui para o fortalecimento das relações humanas na atualidade. Diante do quadro do mundo pós-moderno, os objetos museológicos, que são patrimônio cultural, estimulam a convivência entre as pessoas, ao criar o sentido de identidade e coesão social, produzindo as condições de permanência em um ambiente, já que os sujeitos em contato com esses artefatos são inquietados em relação ao passado, à memória, à cultura material e imaterial das 
cidades e também com suas próprias histórias como pessoas. Os museus ajudam em uma educação patrimonial dos habitantes de uma cidade, e assim na renovação de seus aspectos sociais e físicos.

Palavras-chave: Urbanismo; Pós-modernidade; Museus; Patrimônio; Arquitetura.

\section{REFERÊNCIAS}

ANICO, Marta. A pós-modernização da cultura: património e museus na contemporaneidade. Horiz. antropol., Porto Alegre, v. 11, n. 23, p. 71-86, June 2005. Disponível em:

<http://www.scielo.br/scielo.php?script=sci_arttext\&pid=S010471832005000100005\&lng=en\&nrm=iso >. Acesso em: 4 abr. 2018.

ASCHER, François. Os novos princípios do urbanismo. São Paulo: Romano guerra, 2010.

AUGÉ, Marc. Não lugares: introdução a uma antropologia da sobremodernidade. Lisboa: 90 Graus, 1992.

BAUMAN, Zygmunt. Modernidade líquida. Rio de Janeiro: J. Zahar, 2001.

BENÉVOLO, Leonardo. História da cidade. São Paulo: Perspectiva, 1983.

CANCLINI, Néstor. Culturas híbridas: estratégias para entrar e sair da modernidade. São Paulo: EDUSP, 2003.

CURY, Marília Xavier. Exposição: análise metodológica do processo de concepção, montagem e avaliação. Dissertação (Mestrado) - Escola de Comunicações e Artes, Universidade de São Paulo, São Paulo, 1999.

FREITAS, Moacir Fagundes. Museu de cidade: Entrecruzando Patrimônio e Cidades. Múltiplos Olhares em Ciência da Informação, v. 4, n. 1, mar. 2014.

GIDDENS, A. Modernidade e identidade. Rio de Janeiro: J. Zahar, 2003.

GUIMARÃES, Pedro Paulino. Configuração urbana. Evolução, Avaliação, Planejamento e Urbanização. Rio de Janeiro: Prolivros, 2003.

GONCALVES, José Reginaldo Santos. Ressonância, materialidade e subjetividade: as culturas como patrimônios. Horiz. antropol., 2005, v. 11, n. 23, p.15-36. Disponível em: <http://dx.doi.org/10.1590/S0104-7183200500010000>. Acesso em: 4 abr. 2018. 
HALBAWCHS, Maurice. A Memória coletiva. São Paulo: Centauro, 2004.

HABERMAS, J. The political discourse of modernity. Cambridge: MIT Press, 1987.

LASH, S.; URRY, J. Economies of sign and space. London: Sage, 1994.

LYNCH, Kevin. A imagem da cidade. São Paulo: M. Fontes, 1997.

LYOTARD, Jean-François. O Pós-Moderno. Rio de Janeiro: J. Olympio, 1986.

MENESES, Ulpiano T. Bezerra de. O museu de cidade e a consciência de cidade. In: SANTOS, Afonso Carlos Marques dos; KESSEL, Carlos Guimarães: GUIMARAENS, Cêça (Org.). Museus \& Cidades. Livro do Seminário Internacional "Museus e

Cidades". Rio de Janeiro: Museu Histórico Nacional, 2003. p. 255-282.

PELEGRINI, S. C. A. O patrimônio cultural e a materialização das memórias individuais e coletivas. Patrimônio e Memória, Assis, v.1, n. , 2007.

POLLAK, Michael. Memória e identidade social. Estudos Históricos, Rio de Janeiro, v. 5, n. 10, 1992.

SHINN, Terry. Desencantamento da modernidade e da pós-modernidade: diferenciação, fragmentação e a matriz de entrelaçamento. Sci. stud., São Paulo, v. 6, n. 1, p. 43-81, mar. 2008 . Disponível em: http://www.scielo.br/scielo.php?script=sci_arttext\&pid=S167831662008000100003\&lng=en\&nrm=iso. Acesso em: 27 nov. 2017.

WEBER, M. A ética protestante e o espírito do capitalismo. 2. Ed. São Paulo: Pioneira, 2005. 


\section{A RELAÇÃO TEORIA E PRÁTICA EM UM CURSO SUPERIOR: SUBSÍDIOS PARA O GESTOR}

Maria Eleusa Montenegro ${ }^{1}$

Eliete de Pinho Araujo ${ }^{2}$

Altair Stemler da Veiga ${ }^{3}$

\section{RESUMO}

Busca a compreensão da relação entre a teoria e a prática em um curso Superior de uma instituição de ensino superior privada, de Brasília, DF. Trata-se de uma pesquisa qualitativa do tipo estudo de caso. $\mathrm{O}$ instrumento utilizado foi um questionário semiestruturado aplicado a alunos do $3^{\circ}$ e do $4^{\circ}$ semestres. Os resultados alcançados foram: existe relação entre a teoria e as condições socioeconômicas, políticas e culturais da sociedade; os conteúdos do curso são relacionados à realidade educacional do DF; os materiais e a bibliografia encontramse atualizados; as técnicas e os recursos estabelecem a relação estudada; há incentivo à atitude investigativa; as avaliações exigem a relação entre a teoria e a prática. Os alunos demonstraram "saber" responder às questões sobre a forma em que é evidenciada essa relação, mas as pesquisadoras consideram que definir a relação entre a teoria e a prática é uma tarefa difícil, mesmo tendo uma linha teórica com apoio. Todas as matérias e disciplinas da educação formal necessitam para o seu ensino de qualidade relacionarem a teoria à prática, sob pena de repassarem um conhecimento descontextualizado e sem significado para os alunos, o que não levará à verdadeira aprendizagem. Entretanto, a forma como essa relação está se dando no curso, o quantum e a pertinência dessa relação, ou se essa relação está sendo efetivada, são pouco investigados. O problema central desta pesquisa, portanto, foi verificar a ocorrência da relação entre a teoria e a prática e até que ponto ela está sendo trabalhada ao longo do currículo de um curso superior do UniCEUB, e propor, se necessário, ações que possam contribuir para o desenvolvimento do curso. Entende-se que a relação entre a teoria e a prática, conforme Candau e Lelis, (2014, p.63) é de "indissociabilidade, mas não de identidade, tendo cada uma delas sua identidade própria". O trabalho encontra-se estruturado como pesquisa qualitativa, a

\footnotetext{
${ }^{1}$ Centro Universitário de Brasília / maria.montenegro@ceub.edu.br

${ }^{2}$ Centro Universitário de Brasília / eliete.araujo@ceub.edu.br

${ }^{3}$ Centro Universitário de Brasília/ stemler@terra.com.br
} 
qual, segundo Minayo (2010, p. 21-22), “[...] preocupa-se, nas ciências sociais, com um nível de realidade que não pode ser quantificado, ou seja, ela trabalha com o universo de significados, motivos, aspirações, crenças, valores e atitudes [...]”. Foram pesquisados 29 alunos do $3^{\circ}$ e do $4^{\circ}$ semestres de um curso superior do UniCEUB, do turno noturno. $\mathrm{O}$ instrumento utilizado para obtenção dos dados foi um questionário semiestruturado, aplicado aos alunos, bem como roteiros de análise documental dos seguintes materiais dos professores: planos de ensino; instrumentos de avaliação da aprendizagem; outros materiais apresentados, como roteiros de trabalhos e/ou atividades realizadas em sala, textos, exercícios. As categorias selecionadas para a análise e a discussão dos dados recolhidos pelo questionário e por meio da análise documental foram: a) relação da disciplina com as condições socioeconômicas, políticas e culturais da sociedade; b) aplicação dos conteúdos à realidade cotidiana dos alunos; c) atualização do material e da bibliografia; d) técnicas e recursos utilizados; e) atitude investigativa e f) instrumentos de avaliação utilizados. A análise e a discussão dos dados, relacionadas aos objetivos da pesquisa e ao referencial teórico utilizado constituíram os resultados da pesquisa, descritos a seguir. Dos 29 alunos pesquisados, 26 são do sexo feminino, 20 encontravam-se na faixa etária de 21 a 30 anos, 18 eram solteiros e 17 trabalhavam, tendo 6 escolhido a profissão docente. Entre os alunos, 14 são brasilienses. Quanto à procedência escolar, 19 concluíram o ensino fundamental e 14, o ensino médio em escolas públicas. Aproximadamente $76 \%$ dos alunos disseram acreditar que, de alguma forma, existe relação entre a teoria e as condições socioeconômicas, políticas e culturais da sociedade. Os argumentos utilizados por eles foram: aproveitamento de fatos ocorridos no Brasil e no mundo, pesquisa de campo, artigos de jornais e revistas, filmes, situações hipotéticas, e ligação com o cotidiano e com a realidade do ensino fundamental. Nesse sentido, Vasquez (2007) afirma que "a compreensão da realidade, sustentada na reflexão teórica, é condição para a prática transformadora, ou seja, a práxis. A atividade transformadora é, então, atividade informada teoricamente". Dos 29 alunos participantes, 21 perceberam que a relação entre os conteúdos e a realidade educacional do DF ocorria em algum momento do curso. Os fatores apresentados para essa relação foram: trabalho de campo, visita à sala de aula, experiência dos colegas docentes, projetos, exemplos sobre a realidade da educação pública e privada e comparação com outras localidades. Constatou-se, portanto, unanimidade quanto a esse aspecto, importante para o processo educativo. Em relação ao trabalho de forma concreta e ao incentivo à aplicação dos conteúdos em classe e extraclasse como fatores que promovem a relação entre a teoria e a prática, 28 alunos afirmaram que a relação ocorre eventualmente, e 26 afirmaram que, de algum modo, a utilização de técnicas e de recursos também favorece essa relação. As evidências, nesse sentido, foram: recursos didáticos e audiovisuais, seminários, observações, jogos, simulação de aulas, dinâmicas, visitas, aulas práticas, exemplos, projetos, oficinas, pesquisa de campo, filmes, computador e aulas dialogadas. Sobre 
esse aspecto, André e Mediano (2014, p. 167) dizem que "o ensino precisa estar calcado na experiência concreta dos alunos, exigindo também uma atuação fundamental do professor, que vai transformar a massa de conhecimentos existentes numa matéria preparada, ordenada e simplificada para ser assimilada pelo aluno". Quanto ao incentivo à atitude investigativa, 26 alunos afirmaram que existe esse incentivo em algum momento do curso. A evidência sobre esse aspecto foi percebida mediante: utilização de situações-problema, questionamentos, textos diversificados, observação da prática, projetos, pesquisa, relatórios de observação e seminários. Sobre a importância do processo de investigação na escola, Rezende (2002, p. 203) diz que "[...] a pesquisa qualitativa tem servido de referência para as análises de fenômenos menos evidentes, como no caso das relações de poder e das representações sociais" [grifo do autor]. Vinte e três alunos identificaram que a avaliação utilizada pelo professor demonstrava, de alguma maneira, a relação entre a teoria e a prática, o que é evidenciado por meio da aferição das habilidades intelectuais, das atividades práticas, dos estudos de caso, das situações-problema, da avaliação contínua, da utilização de exemplos e da ligação do conteúdo à prática. Mas muitos alunos salientaram que, muitas vezes, a avaliação utilizada caracteriza-se pelo "tradicionalismo", ocorrendo ênfase na teoria. Uma avaliação formativa, segundo Berbel et al (2002, p. 39), caso ocorra, fará com que "a relação entre a teoria e a prática terá mais espaço para ocorrer, consequentemente, a preparação para a vida e para a profissão será facilitada". Dos nove professores que apresentaram materiais pedagógicos, sete demonstraram relacionar a teoria às condições socioeconômicas, políticas e culturais da sociedade. A atitude investigativa pôde ser percebida em materiais de seis professores. Em um dos textos é valorizada a aprendizagem por descobrimento, ou seja, o conhecimento por seus próprios meios, fazendo com que o aluno tenha uma atitude investigativa. Dos nove planos de ensino analisados, sete encontravam-se atualizados, com livros editados até um ou dois anos antes da coleta do material para análise. Somente um plano de ensino indicou artigos de revistas e de Internet e um relacionou uma dissertação de mestrado, que era da autoria do responsável pela disciplina. Com relação aos procedimentos metodológicos e avaliação da aprendizagem, existia uma variedade de recursos, o que pode facilitar a relação em questão. Constatou-se que nesta instituição de ensino a relação teoria-prática efetiva-se na práxis de um curso do Ensino Superior, o que poderá propiciar ao futuro educador uma formação ampla, voltada para a realidade social e educacional. Considerou-se que definir a abrangência da relação entre a teoria e a prática e a forma em que ela se evidencia constituiu-se uma tarefa difícil, mesmo tendo uma linha teórica como apoio. Sugere-se pesquisas futuras sobre o tema, tão abordado teoricamente, mas pouco pesquisado na prática, para maior contribuição ao estudo do tema. Conhecer sobre a relação entre a teoria e a prática propicia ao professor a realização de um trabalho docente de qualidade e possibilita a 
reflexão, a contextualização, a criatividade e a transformação do processo ensinoaprendizagem.

Palavras-chave: Prática pedagógica; Relação entre a teoria e a prática; Formação de professores.

\section{REFERÊNCIAS}

ANDRÉ, M. E. D. A.; MEDIANO, Z. D. O cotidiano da escola: elementos para a construção de uma Didática Fundamental. In: CANDAU, V. (Org.). Rumo a uma nova Didática. 12. ed. Petrópolis: Vozes, 2014.

BERBEL, Neusi Aparecida N. et al. Avaliação da aprendizagem no ensino superior: um retrato em cinco dimensões. Londrina: UEL, 2002.

CANDAU, Vera M.; LELIS, Isabel A. A relação teoria-prática na formação do educador. In: CANDAU, Vera M. Rumo a uma nova didática. 12. ed. Petrópolis: Vozes, 2014.

MINAYO, Maria Cecília de Souza (Org.). Pesquisa social: teoria, método e criatividade. Petrópolis: Vozes, 2010.

REZENDE, L. M. G. de. Pesquisa e prática pedagógica I. In: TEIXEIRA, Fátima Emília da Conceição (Org.). Guia de formação para professores das séries iniciais. Brasília: UniCEUB, 2002.

VASQUEZ, Adolfo S. Filosofia da práxis. Rio de Janeiro: Paz e Terra, 2007 


\title{
ARQUITETURA VERDE: AS PAISAGENS URBANAS NA CIDADE CONTEMPORÂNEA - A BIOMIMÉTICA CONTEMPLANDO EFICIÊNCIA E CONSTRUÇÃO SUSTENTÁVEL
}

\author{
Eliete de Pinho Araujo ${ }^{1}$
}

Manuel García Docampo ${ }^{2}$

\section{RESUMO}

A grande relevância dos espaços verdes, atualmente um campo de estudo, a UNESCO, por meio do programa El Hombre e a Biosfera, é dedicada aos aspectos ecológicos dos sistemas urbanos e entre eles, os espaços verdes como elemento fundamental do equilíbrio ecológico das cidades, pois esses constituem um pequeno ecossistema integrado ao solo, à água, à vegetação e à fauna. Esses espaços contribuem para uma melhora do condicionamento das cidades e favorecem a captação de oxigênio, reduzem a contaminação atmosférica, suavizam as temperaturas extremas e amortizam a erosão do solo. Há de se destacar também a importância da vegetação sobre o equilíbrio psicossomático da população. Um dos principais problemas ambientais das cidades são as emissões de gases, como o CO2. As árvores consomem grande parte desses gases e produzem uma grande quantidade de oxigênio. A vegetação na zona urbana também serve para filtrar partículas de pó e dos gases contaminantes que se encontram suspenso na atmosfera, como o flúor e o ácido sulfúrico. As folhas são capazes de filtrar vírus. Um estudo das Nações Unidas para a cidade de Chicago estima que as árvores eliminem 5.575 toneladas de contaminantes atmosféricos por ano, que para um serviço de limpeza custaria 9 milhões de dólares. A massa arbórea equilibra os valores de temperatura e umidade, assim a diferença térmica de uma cidade com árvores e sem árvores pode variar entre $2^{\circ} \mathrm{C} \mathrm{e} 4^{\circ} \mathrm{C}$. A umidade relativa pode ser superior a $10 \%$ em cidades arborizadas. Estima-se que o efeito refrescante das árvores que transpiram 450 litros por dia equivale a um ar condicionado funcionando durante 20 horas por dia em um ambiente médio com 5 pessoas. Uma das agressões mais graves nas cidades é a acústica e a principal fonte de ruído nas cidades é o tráfego. As massas arbóreas

\footnotetext{
${ }^{1}$ UniCEUB /Prof. ${ }^{\text {. D Dr a }}$, Brasília DF Brasil

Curso de Arquitetura e Urbanismo - FATECS/ eliete.araujo@ceub.edu.br

${ }^{2}$ UDC /Prof. Dr., A Coruña, Espanha

Faculdade de Sociologia - GET/ docampo@udc.es
} 
funcionam com barreiras acústicas que isolam determinados espaços, como os parques. Os parques urbanos contam com uma cobertura vegetal importante incluindo árvores e arbustos. No interior deles são formados diversos recintos que abrigam equipamentos e atividades variadas. Seu tamanho e a presença de vegetação abundante permitem um isolamento quase total dos ruídos no exterior, proporcionando bem estar aos usuários. Em geral, o raio de influência dos parques urbanos é mais amplo que o bairro onde ele está localizado, recebe visitantes do local e de outros lugares. A necessidade do verde urbano é inversamente proporcional ao grau de ruralização da vida cotidiana. Por exemplo, os habitantes de pequenas cidades, que se fundamentam na agricultura, são rodeados de campos, bosques e prados, têm em abundância o que é escasso em cidades grandes. Quanto maior a população urbana, maior serão os problemas urbanísticos para se criar os espaços verdes necessários, assim como para administrar tais espaços. O verde urbano pode trazer benefícios psicológicos relevantes para a população, criando espaços que favorecem a recreação e dignifica o entorno. Os parques e jardins urbanos são espaços fundamentais na educação ambiental, transmitem percepções na troca das estações ao longo do ano. Nos parques e jardins a vegetação atua como barreira que permite o isolamento visual do trafego e da paisagem urbana que contribuem para o bem-estar do usuário. Como James Corner escreve em seu ensaio "Terra Fluxus", as qualidades da paisagem que atualmente estão sendo abraçadas são, em grande parte, do seu "alcance conceitual", com a sua capacidade de teorizar sítios, territórios, ecossistemas, redes e infraestruturas e organizar grandes áreas urbanas. Em particular, as temáticas de organização, interação dinâmica, ecologia e técnica apontam para um urbanismo mais lento e emergente, mais parecido com a complexidade real das cidades e oferecendo uma alternativa aos mecanismos rígidos do planejamento centralista. O significado dessas reformulações - embora ainda não resolvidas fisicamente-demonstram uma profunda reconsideração e, portanto, um trampolim especulativo, para um conjunto evoluído de práticas de paisagem que ultrapassam as noções simplistas da forma da cidade, do espaço urbano e do processo de design, para uma renovação e ampliação arsenal de teorias, técnicas, modelos e eventuais tipos de paisagens subjacentes, separadas, conectadas, ampliadas e resistentes aos objetos mais tradicionais do urbanismo. Este artigo tem como finalidade abordar o conceito de espaços verdes, jardins, arquitetura verde, abrangendo desde seu surgimento até sua aplicação nos dias de hoje. Consiste em uma nova aplicação da arquitetura por um conjunto de práticas, conceitos e técnicas, que fazem total diferença na eficiência da construção sustentável. Aborda de forma resumida os principais aspectos tratados no livro "The Landscape Urbanism Reader". Discutem-se, as paisagens urbanas e os processos que levaram à sua formação. Apresenta, de forma sucinta, a nova linguagem introduzida pelo autor ao explicar o processo de mudança rápida de cidade para paisagem por meio de discussões sobre a cidade contemporânea. Abordar a arquitetura verde vem desde a 
concepção do projeto arquitetônico sustentável, passando pelo profissional responsável que leva pelos detalhes a otimização de recursos naturais e o menor impacto dos edifícios no meio ambiente. Como exemplo, leva-se em conta condições do clima e dos ecossistemas do entorno dos edifícios, aproveitando o que estes têm a oferecer, causando o mínimo de impacto possível ao meio ambiente onde será executada a obra. Mais do que apenas uma terminologia técnica, a arquitetura verde é um modo novo de olhar e de criar. É um esforço constante pela preservação do planeta e, de maneira mais localizada, do ambiente em que as pessoas viverão. A diversidade dos usos em um mesmo espaço público é a base para assegurar um espaço de convivência e de tolerância que ajuda a fomentar o respeito ao bem comum e, portanto, ajuda a desenvolver um comportamento cívico que resulta em algo imprescindível para a vida em sociedade. A diversidade dos usos em um mesmo espaço público é a base para assegurar um espaço de convivência e de tolerância que ajuda a fomentar o respeito ao bem comum e, portanto, ajuda a desenvolver um comportamento cívico que resulta em algo imprescindível para a vida em sociedade. As zonas verdes são excelentes plataformas para o conhecimento da natureza domesticada, desenhada na medida para os usuários, que irá se transformar em apreço e respeito por aquilo que se conhece e entende. Os principais aspectos que devem ser considerados em um espaço verde ideal são: um espaço que mostre uma preocupação com o beneficio social e ambiental, e que os recursos (econômicos, materiais, humanos, naturais, etc.) sejam mínimos. Esse último aspecto é fácil de atingir em sua grande maioria ao adotar um modelo de planejamento, desenho e gestão sustentáveis. Projetos que aderem o uso de vegetação que exija pouca manutenção são valorizados. Esse deve ser o ponto de partida de um projeto: ter um equilíbrio entre os aspectos paisagísticos, estéticos e ambientais com a funcionalidade do espaço. No momento de se projetar uma zona verde é indispensável analisar o entorno e a quem esse espaço vai ser destino. Deve-se pesquisar como e quem são as pessoas que serão influenciadas por essa zona verde. Um estudo mais aprofundado permite definir diferentes grupos de usuários com expectativas, demandas e necessidades específicas. Esses fatores influenciam diretamente nos parques, por isso são criadas áreas para repouso, atividades esportivas, calçadas, área para as crianças brincarem, espaços para cachorros, áreas reservadas para piquenique. Trata-se de satisfazer as demandas sem que os diferentes usos interfiram entre si. Apesar dos jardins históricos fazerem parte da trama verde da cidade, a sua manutenção e sua conservação não podem ser tratadas da mesma forma que o restante das zonas verdes da cidade e devem ter um planejamento de manutenção exclusivo. Cada jardim deve ser estudado individualmente, devem ser conhecidos seus antecedentes, suas transformações que foram feitas ao longo do tempo e sua vegetação original. Cada um desses projetos testemunhou inovações nos processos técnicos e organizacionais, que contribuíram para o que Reed acredita ser um novo conjunto de práticas profissionais caracterizadas pela ênfase nos aspectos 
operacionais e orientados para o desempenho dos processos paisagísticos e da urbanização e com foco na logística e mecanismos. Reed resume o urbanismo da paisagem como um conjunto de ideias e frameworks que são baseados em desempenho, orientados para a pesquisa, logísticos, em rede. Pela arquitetura verde surgiu o estudo da arquitetura juntamente com a biomimética, que é uma ciência que estuda os meios criativos no qual a natureza encontra para se adaptar, crescer e viver. Assim, requalificou, de maneira sábia, o uso da arquitetura junto da natureza em prol dos seres vivos. A biomimética prova que, além das belas paisagens e da infinidade de recursos, a natureza tem diversas soluções que podem contribuir para o desenvolvimento da arquitetura sustentável, ajudando na criação de projetos duradouros. Quando unida à ciência, é inegável a sua contribuição para a qualidade de vida da sociedade como um todo.

Palavras-chave: Arquitetura verde; Biomimética; Eficiência; Construção Sustentável; Paisagens Urbanas; Cidade Contemporânea.

\section{REFERÊNCIAS}

CALAZA MARTINEZ, Pedro. Infraestructura verde: sistema natural de salud pública. Madrid: Mundi-Prensa, 2017.

FALCÓN, Antoni. Espacios verdes para una ciudad sostenible. Planificación, proyecto, mantenimiento y gestión. GG, 2007.

FULTON, Gale. The Landscape Urbanism Reader. A Review by Gale Fulton. In: WALDHEIM, Charles. The Landscape Urbanism Reader. New York: Princeton Archtectural Press. 2006. 


\section{AS CALÇADAS DA ESPLANADA DOS MINISTÉRIOS: ASPECTOS HISTÓRICOS, DE PROJETO E SUA CONFORMIDADE COM A LEGISLAÇÃO E NORMATIZAÇÃOO VIGENTES}

Hugo Oliveira Costa ${ }^{1}$

Neusa Maria Bezerra Mota ${ }^{2}$

\section{RESUMO}

Os aspectos de acessibilidade e mobilidade urbana voltado para pedestres, de maneira a abranger as calçadas, como parte dos espaços e recursos públicos disponíveis para a população que, em algum momento do seu dia, opta por não utilizar o transporte motorizado privado ou público, têm encontrado, a cada dia, um importante espaço nas pesquisas de interesse científico e acadêmico. Um dos sistemas que por muitos é esquecido, mesmo sendo essencial, é o transporte terrestre por força motor própria, ou seja: o caminhar. $\mathrm{O}$ ato de caminhar é a forma de transporte mais utilizada dentro e fora dos grandes centros urbanos. Todas as pessoas são pedestres em algum momento do seu dia. Um cidadão é igual a qualquer outro cidadão perante a lei, tendo garantido os mesmos direitos e deveres, mesmo que apresente características diferenciadas, tanto fisicamente como psicologicamente. Dentre os pedestres, existem aqueles que requerem um olhar diferenciado, a saber: portadores de necessidades especiais, como por exemplo os cadeirantes, ou aqueles com dificuldades de locomoção (idosos), ou até mesmo pessoas que apenas tem a locomoção alterada por fatores passageiros (muletas, ou mães com carrinhos de bebê). Todos esses cidadãos tem o direito de se locomover pelo espaço público de maneira igual, de forma que a lei não os considera deficientes, e sim portadores de necessidades especiais. Neste caso, na maioria das vezes, os espaços estão inadequados para estes usuários, que, a cada dia, tem o seu direito de ir e vir prejudicado, precisam estar em conformidade as referidas necessidades. Reconhecendo que os espaços disponíveis para a locomoção dos pedestres são inadequados, se faz necessário considerar os aspectos técnicos de forma a minorar este problemas, com envolvimento prévio dos órgãos responsáveis e investimento na

\footnotetext{
${ }^{1}$ Centro Universitário de Brasília / eng.hugooc@gmail.com

${ }^{2}$ Centro Universitário de Brasília/neusa.mota@ceub.edu.br
} 
fase de projeto das calçadas que, oferecerão o livre caminhar pela cidade, de forma a alcançar um nível de acessibilidade favorável e abrangente a qualquer possível usuário do espaço público. Nesse sentido, o objetivo da pesquisa consiste na realização de um estudo sobre as calçadas da Esplanada dos Ministérios em BrasíliaDF, local onde se encontram a maior parte dos bens do Patrimônio Cultural da Humanidade, conferidos pela Organização das Nações Unidas para a Educação, a Ciência e a Cultura (Unesco), com uma abordagem nos aspectos históricos, de projeto urbano, e inspeção em campo para avaliação das condições atuais das calçadas enquanto sistema construtivo, com foco nas principais manifestações patológicas e por fim na análise de conformidade do projeto e da execução com a legislação e normatização vigentes. Coisas simples como faixas de pedestres, em localizações estratégicas, rampas de acesso para cadeirantes, com inclinações adequadas e posicionamentos adequados de mobiliários urbanos, são detalhes previstos em normas e que, mesmo sendo de fácil acesso, a grande maioria da população não tem conhecimento ou mesmo interesse. No entanto, uma vez que o poder público delegue a concepção de qualquer obra em área pública, o responsável deve ter pleno conhecimento do que se pode, ou não, e do que se deve, ou não fazer. O estudo foi voltado para os diversos usuários dos espaços públicos, em especial os pedestres, levando-se em consideração as diferentes características físicas e psicológicas que os mesmos podem apresentar. A escolha do objeto de estudo, a Esplanada dos Ministérios, foi dada devido a importância que este ambiente carrega tanto histórica, como em termos arquitetônicos, para a cidade e para o país, focando o estudo nas calçadas principais e secundárias, localizadas entre os ministérios. Os diversos estudos realizados em outras regiões do Brasil, acrescentam uma extensa base bibliográfica para o desenvolvimento deste trabalho, inclusive oferecendo características a serem implementadas nos projetos de calçadas, de maneira a tornálas adequadas e com desempenho satisfatório a sua principal finalidade, como exemplo, do ponto de vista da acessibilidade, com dimensões coerentes, espaços agradáveis, drenagem urbana implementada com mobiliário e/ou arborização, sinalização tátil e visual, dentre outras características. Citam-se alguns autores que desenvolveram estudos nesta linha de pesquisa: Aguiar (2003), Lunaro (2004), Melo (2005), Keppe (2007), Miotti (2012) e Santos et al (2017). Souza et al. (2012) realizaram um levantamento das condições das calçadas em diversas capitais brasileiras, em que foram avaliadas características como irregularidades no piso, largura mínima, iluminação, dentre outros, e a cada característica uma pontuação de 0 a 10 foi atribuida. O resultado do respectivo estudo, para as calçadas da Esplanada dos Ministérios, correspondeu a uma pontuação média de 7,5, o que representa uma qualidade abaixo do ideal. Atualmente a situação observada difere um pouco do resultado por eles obtidos, considerando a vida útil atual deste sistema e a precariedade das manutenções preventivas e corretivas, por parte do poder público. Nesta pesquisa, pretende-se que os resultados observados em campo, sejam 
confrontados com a normatização e legislação vigentes. Também, se busca revelar as incoerências e as barreiras que os pedestres usuários, do referido espaço público, diariamente, precisam superar, e que decorrem de problemas relacionados a concepção de projeto, execução e manutenção, e que para serem corrigidos terão um custo, que poderá ser de até cinco vezes maior do que seria na fase de projeto, de acordo com a Lei de Sitter de 1984, citada por Helene (1992). Ao concluir que realidade observada é desatualizada em relação a data de sua concepção versus a normatização e desenvolvimento dos conhecimentos, tem-se atualmente, sugerido uma atualização nas calçadas de maneira a adequá-las as tecnologias que, tem-se disponível na atualidade, e com isso prolongar e aumentar sua vida útil e receptividade aos diversos usuários, respectivamente.

Palavras-chave: Pedestre; Acessibilidade; Calçada.

\section{REFERÊNCIAS}

AGUIAR, F.O. Análise de métodos para avaliação da qualidade de calçadas. 2003. Dissertação (Mestrado) - Programa de pós-graduação em engenharia urbana, Universidade de São Carlos, São Paulo, SP, 2003.

HELENE, P. R. L. Manual para reparo, reforço e proteção de estruturas de concreto. São Paulo: PINI, 1992.

KEPPE C. L. G. J. Formulação de um indicador de acessibilidade das calçadas e travessias. São Carlos: Universidade de São Carlos, 2007.

LUNARO, Adriana. Avaliação dos espaços urbanos segundo a percepção das pessoas idosas. 2004. 118 f. Dissertação (Mestrado em Ciências Exatas e da Terra) Universidade Federal de São Carlos, São Carlos, 2004.

MELO, F. B. Proposição de Medidas Favorecedoras à Acessibilidade e Mobilidade de Pedestres em Áreas Urbanas. Estudo de Caso: o centro de Fortaleza. 2005. Dissertação (Mestrado) - Programa de Mestrado em Engenharia de Transportes, Universidade Federal do Ceará, Fortaleza, CE, 2005.

MIOTTI, Luiz Antonio. A engenharia civil como instrumento para a acessibilidade em ambientes construídos e a realidade de calçadas e passeios urbanos. REEC: Revista Eletrônica de Engenharia Civil. Universidade federal de Goiás, UFG/GO, 2012. 
SOUZA. et al. Levantamento “Calçadas do Brasil”. Mobilize. Disponivel em: <http://www.mobilize.org.br/campanhas/calcadas-do-brasil/levantamento> Acesso em: 18 mar. 2018.

SANTOS et al. Oito princípios da calçada. WRI Brasil, 20 


\section{COMPONENTES DO DÉFICITHABITACIONAL NO DISTRITO FEDERAL}

Ana Luiza Novais de Melo ${ }^{1}$

Fabiano Jose A. Sobreira ${ }^{2}$

\section{RESUMO}

O artigo aborda a análise dos componentes do déficit habitacional em cada região do Brasil em comparação com o Distrito Federal. São abordadas as origens e o panorama atual da habitação social no Brasil, a partir de conceitos e informações apresentadas por Nabil Bonduki, Raquel Rolnik, Milton Santos e Aldo Paviani. O objetivo do artigo é analisar criticamente os diferentes elementos que constituem o déficit habitacional nos diversos Estados do país em comparação com o Distrito Federal, com enfoque especial no ônus excessivo com o aluguel; através da metodologia de catalogação e análise de dados e confrontação de resultados à luz da bibliografia selecionada. Segundo Nabil Bonduki (2014) o problema da habitação no Brasil está associado diretamente à questão social e tem relação com a transição de uma economia de base agrário-exportadora para uma economia baseada na industrialização das cidades. Nesse processo a oferta de infraestrutura e habitação não acompanhou a crescente demanda urbana, o que gerou o déficit habitacional e a exclusão social urbana. O papel da habitação na política de redução do custo da força de trabalho e de proteção aos trabalhadores com carteira assinada traz a importância desse ciclo de conjuntos que devem sempre estar interligados, já que a habitação "ocupa um lugar importante no ciclo de rotação do capital, tanto privado quanto social: é um componente decisivo do famoso 'consumo médio' que fixa o valor da força de trabalho" (LIPIETZ, 1982). No início da urbanização das cidades o Estado percebeu que era preciso lidar com a questão da moradia, em especial quando atingia limites de insalubridade que afetavam a saúde pública. Observou-se que a moradia precária era um problema não apenas dos desabrigados, mas de toda a sociedade, que ficava exposta a epidemias. Nesse contexto, dos anos 1930, por mais que prevalecesse uma ótica liberal, em que o Estado evitava se envolver na ordem econômica e nas áreas de atuação do setor privado, as ações higienistas foram a base

\footnotetext{
${ }^{1}$ Centro Universitário de Brasília / ananovais.arq@gmail.com

${ }^{2}$ Câmara dos Deputados e Centro Universitário de Brasília / fabiano.sobreira@ceub.edu.br
} 
das futuras políticas de habitação social, desenvolvidas ao longo dos anos 1940 e 1950. A pressão do Estado, ao exigir condições mínimas de higiene, levou os empresários a criarem núcleos de moradia destinados aos trabalhadores: foram as chamadas vilas operárias, onde as condições de moradia oferecidas eram as mínimas exigidas e os trabalhadores ficavam submetidos ao controle patronal de horários, vida social, comportamento e moral (BONDUKI, 2014, p. 21). Esse modelo de conjunto habitacional equipado por áreas destinadas a atividades comunitárias como comércio, praças, igrejas, bibliotecas e escolas se aproximava ao que defendiam as ideias modernistas de habitação dos anos 30 e 40, segundo as quais habitação não é só a moradia, mas todo um conjunto de equipamentos coletivos nescessários à vida moderna (BONDUKI, 2014). Em questões econômicas, para movimentar o mercado, se pensava que "a casa própria faria do morador um conservador que defende o direito de propriedade" frase atribuída a Sandra Cavalcanti, primeira presidenta do $\mathrm{BNH}$, onde a intenção não era apenas dar a moradia no sentido de abrigar e sim dar uma propriedade privada, o que inibiria futuramente a ideia de coletividade, expressando a preocupação de fazer da política habitacional um instrumento de combate às ideias comunistas e progressistas (BONDUKI, 2014, p. 63). A ideia da habitação como propriedade individual e não como um serviço coletivo aumentou ainda mais as desigualdades sociais mesmo em um contexto de desenvolvimento industrial no país (BONDUKI, 2014). Segundo a Fundação João Pinheiro no Déficit Habitacional Municipal do Brasil em 2010 se destacam as seguintes causa: coabitação familiar 43,1\%, ônus excessivo com aluguel 30,6\%, domicílios precários $19,4 \%$ e adensamento excessivo de domicílios 6,9\%. Especificamente, mais de $70 \%$ do déficit habitacional no Brasil é composto pela coabitação familiar $(43,1 \%)$ e pelo ônus excessivo com aluguel $(30,6 \%)$. Esses dois componentes, juntos, representam o déficit de 5,1 milhões de unidades. Domicílios precários (19,4\%); e adensamento excessivo de domicílios alugados (6,9\%) são os componentes menos expressivos e que, juntos, correspondem a cerca de 1,8 milhões de unidades. $\mathrm{O}$ déficit habitacional observado ao longo da história se agrava à medida que o lucro através do aluguel de moradias leva os empresários e construtoras a produzir imóveis com o mínimo de estrutura e espaço para que sejam alugados; e mesmo com o baixo valor e a precariedade nem todos possuem condições para alugar esses espaços e acabam se mudando cada vez para áreas mais isoladas do centro, o que aconteceu com os cortiços e as vilas operárias. Assemelhando-se ao processo de gentrificação onde os especuladores compram os lotes e os transformam em imóveis voltados a construções multifamiliares para um número maior de lucro com aluguéis sem a preocupação com os equipamentos públicos, esse processo afasta a população e os moradores de origem, os deslocando para as favelas. Como cita Milton Santos esse processo produtivo ofende, expulsa e desenraízam as pessoas, sem assegurar o direito à cidade ou, ao menos direito ao entorno; essas migrações agridem o indivíduo, roubando-lhe parte do ser e 
obrigando-o a uma nova e dura adaptação em seu novo lugar. "Morar na periferia é se condenar duas vezes à pobreza. À pobreza gerada pelo modelo econômico e da pobreza gerada pelo modelo territorial" (SANTOS, 1987, p. 115). Segundo os gráficos analisados podemos observar que ao longo dos anos o único componente que permanece em constante crescimento é o ônus excessivo com aluguel, o que revela o impacto da financeirização da moradia como elemento determinante do déficit contemporâneo. O conceito de déficit habitacinal é visto não só como a falta de moradia, mas como a reunião de todos os componentes relaci\$nados, entre eles o destaque para o ônus excessivo com o aluguel e a financeirização da moradia.

Palavras-chave: Déficit Habitacional; Habitação social; Distrito Federal.

\section{REFERÊNCIAS}

BONDUKI, Nabil. Os pioneiros da habitação social. São Paulo: Unesp, 2014. v. 1.

PAVIANI, A. O crescimento das metópoles e problemáticas de lenta solução.

Desafios do Desenvolvimento, v. 10, p. 55, 2013.

ROLNIK, Raquel. Guerra dos Lugares. São Paulo: Boitempo, 2015.

SANTOS, Milton. O espaço do cidadão. São Paulo: EDUSP, 1987. 


\section{CONCURSOS DE HABITAÇÃO SOCIAL EM BRASÍLIA: ARQUITETURA, QUALIDADE E SUSTENTABILIDADE}

Fabiano Jose A. Sobreira ${ }^{1}$

\section{RESUMO}

Trata-se de apresentar resultados preliminares de análises e reflexões sobre arquitetura, qualidade e sustentabilidade em projetos de habitação social na região metropolitana de Brasília (Distrito Federal, Brasil), a partir de concursos de arquitetura promovidos pela Companhia de Desenvolvimento Habitacional do Distrito Federal (CODHAB-DF). O objetivo é a análise do projeto de arquitetura e urbanismo em situação de concurso nas diversas abordagens e escalas (do espaço urbano à unidade habitacional). Mais especificamente, foram analisados os concursos para unidades habitacionais coletivas no Sol Nascente e no Pôr do Sol, regiões administrativas situadas no entorno do Plano Piloto de Brasília, Patrimônio Cultural da Humanidade. Como metodologia, trata-se de confrontação analítica de projetos a partir de premissas e parâmetros construídos pela relação entre o contexto local e estudos consolidados sobre a temática da habitação social. Nesse sentido, foram inicialmente estudadas as principais reflexões relacionadas ao tema do projeto de habitação social no Brasil, contextualizadas em seguida na realidade do Distrito Federal, a fim de extrair parâmetros analíticos para o estudo dos projetos. $\mathrm{O}$ conjunto urbano de Brasília, tombado como Patrimônio Cultural da Humanidade é apenas uma pequena parcela de uma grande metrópole que, como tantas outras no Brasil, são marcadas pela exclusão social. De acordo com o memorial de Lucio Costa, apresentado ao concurso do Plano Piloto, o projeto havia sido concebido de forma que a gradação social poderia ser facilmente dosada, com "certo grau de coexistência social, evitando-se assim uma indevida e indesejável estratificação". A intenção era "impedir a enquistação de favelas tanto na periferia urbana quanto na rural". Mas a realidade (social e espacial) já se configurava em direção oposta, antes mesmo de inaugurada a nova Capital. Não se tratava de um "canteiro de obras" transitório, mas de fragmentos da cidade, que já se formavam e se firmavam como partes inevitáveis, necessárias e indissociáveis - porém não reconhecidas - da futura metrópole, antes mesmo da inauguração da Capital: Candangolândia (1956), Núcleo Bandeirante (1956), Varjão (1956), Taguatinga (1958) e Cruzeiro (1959). A informalidade e a

${ }^{1}$ Centro Universitário de Brasília / fabiano.sobreira@ceub.edu.br 
precariedade urbana em Brasília, enfim, não são eventos recentes; infelizmente, são partes de uma dinâmica social e urbana que está na origem da formação da Capital. Hoje, o Plano-Piloto (área tombada e preservada como Patrimônio Histórico) abriga cerca de 220 mil habitantes, isto é, menos de 10\% da metrópole do Distrito Federal cuja população já alcança cerca de quase 3 milhões de habitantes. Mais de $90 \%$ da população, portanto, ocupa áreas de configurações urbanas diversas (áreas de grande verticalização, favelas, loteamentos irregulares, condomínios fechados, bairros horizontais, etc), que pouco reproduzem o espírito da Super-Quadra, do PlanoPiloto, um dos pontos altos do projeto inaugurado em 1960. O déficit habitacional crônico e as respostas descentralizadas e fragmentadas da população (favelas e loteamentos irregulares), que marcam a realidade das cidades brasileiras são expressões urbanas da desigualdade social e da segregação socioespacial que se observa nessas sociedades, desde sua origem. As favelas, assim como os loteamentos clandestinos, são parte dessas respostas urbanas à ausência de uma política urbana mais efetiva e inclusiva. Como ressalta Bonduki (2015), o atual quadro da habitação no Brasil é resultado do processo de exclusão territorial que se deu ao longo de décadas. E apesar dos avanços que marcaram o período de redemocratização (a partir dos anos 1990) e das políticas mais recentes de erradicação da miséria (20022012), observa-se que a Política Habitacional sempre esteve mais relacionada às Políticas de Desenvolvimento Econômico do que às estratégias de Planejamento Urbano e de Inclusão Social. No Brasil, como em qualquer outro contexto, os projetos de habitação social são um reflexo das políticas na qual estão inseridos: políticas imediatistas e basedas em metas quantitativas geram projetos sem qualidade, relacionados à produção em série e às macro-metas econômicas; enquanto políticas públicas de longo prazo, baseadas em premissas de inclusão social e de sustentabilidade, geram projetos de maior qualidade, desde a escala do edifício à escala urbana. Nesse contexto, observa-se que um dos elementos determinantes para a qualidade da habitação social é o procedimento de contratação do projeto e, em sua origem, os critérios de escolha e julgamento das soluções. Os concursos de projeto são instrumentos de contratação que priorizam o julgamento qualitativo, democrático e transparente do projeto de arquitetura e urbanismo acima de outros critérios - como experiência do autor, reconhecimento público ou valor da prestação do serviço. Talvez por isso sejam escassos na realidade brasileira. Nos concursos de habitação social promovidos pela CODHAB-DF, os projetos foram analisados pela Comissão Julgadora de acordo com os seguintes critérios básicos, sem hierarquia de prioridade ou caráter eliminatório: a) conceito e inovação, b) adequação às normas, c) clareza do projeto, d) funcionalidade e atendimento ao programa de necessidades, e) sustentabilidade socioambiental, f) exequibilidade, economia e viabilidade técnico-construtiva, g) soluções passivas de conforto térmico e eficiência energética h) contextualização urbana, i) acessibilidade, inclusão e adequação social, j) aspectos plásticos, éticos e estéticos do projeto, k) outros, conforme necessidades advindas do 
caráter do objeto do concurso. Tais critérios foram utilizados como referência pelo Júri de cada concurso e sua apreciação variou conforme o perfil dos julgadores indicados, assim como as demandas programáticas e os contextos específicos, resguardadas as premissas gerais estabelecidas nas bases dos respectivos concursos. Dentre os critérios acima observa-se que pelo menos três estão diretamente ligados ao que podemos considerar "diretrizes bioclimáticas": sustentabiliade socioambiental, soluções passivas de conforto térmico e eficiência energética e contextualização urbana. O Setor Habitacional Sol Nascente está situado em platôs formados por vales de córregos afluentes de um dos rios que integram a Bacia Hidrográfica da Região Administrativa de Ceilândia. Trata-se de Área de Regularização de Interesse Social (ARIS), nos termos do Estatuto da Cidade (Lei 10.257/2001). O concurso para unidades habitacionais no Sol incluiu projetos para 14 lotes distribuídos em três conjuntos (F, G e H da Quadra 700). Cada lote, com áreas entre 1.500 e $1.850 \mathrm{~m} 2$. O programa e a legislação urbana previam tipologias de no máximo 4 pavimentos, de 2 e 3 quartos (sendo facultado o uso do térreo como pilotis ou unidades habitacionais). Além dos projetos de arquitetura das edificações, os proponentes deveriam apresentar soluções de urbanismo para as áreas comuns. Conforme descrito no termo de referência do concurso, o Pôr do Sol é um parcelamento informal e irregular em estágio avançado de consolidação e ocupado predominantemente por população de baixa renda, definido pelo Plano Diretor de Ordenamento Territorial do Distrito Federal (PDOT), Lei Complementar $n^{\circ}$ 803/2009, alterada pela Lei Complementar $n^{\circ} 854$, de 15 de outubro de 2012, como ARIS Pôr do Sol (Ârea de Regularização de Interesse Social). O concurso teve como objetivo selecionar a melhor proposta de desenho urbano para uma área desocupada na qual serão instalados até 4.963 habitantes e 1.518 unidades habitacionais, com o intuito de qualificar o espaço urbano, criar melhores e mais favoráveis condições de vida aos futuros moradores e conceder-lhes o direito à cidade. Conclusões preliminares indicam que os concursos têm se revelado como importantes instrumentos de ampliação do debate sobre a habitação social no Brasil e em Brasília, nos quais as questões relacionadas a patrimônio, inclusão social, impacto ambiental e sustentabilidade são confrontadas. A qualidade das propostas apresentadas nos concursos revela o grande potencial que o instrumento oferece à gestão pública, como meio de superar as limitações usualmente oferecidas pelo mercado. Por outro lado, observa-se que algumas limitações na legislação e nos programas habitacionais têm dificultado a promoção de iniciativas inovadoras e inclusivas, que restringem as possibilidades criativas e dificultam a promoção da inclusão urbana dos projetos de habitação social em Brasília.

Palavras-chave: Concursos de Arquitetura; Habitação Social; Brasília; Distrito Federal.

\section{REFERÊNCIAS}


BONDUKI, N.; KOURY, A. Pioneiros da Habitação Social. Cem Anos de Política Pública. São Paulo: UNESP, 2015. v. 1

ROLNIK, R. Guerra dos lugares. A colonização da terra e da moradia na era das finanças. São Paulo: Boitempo, 2015.

SANTOS, M. A cidade nos países subdesenvolvidos. Rio de Janeiro: Civilização Brasileira, 1965.

SANTOS, M. O espaço da cidadania e outras reflexões. Brasília: Fundação Ulysses Guimarães, 2013.

SOBREIRA, F.; ROMERO, M. Concursos de habitação social em Brasília: reflexões sobre projeto, inclusão e sustentabilidade. In: CONGRESSO INTERNACIONAL DA HABITAÇÃO NO ESPAÇO LUSÓFONO, 4., 2017. Porto e Covilhã. Anais... Porto: Universidade Beira Interior, 2 


\section{(DES)CONTINUIDADES EM BRASÍLIA: ENTRE A PRESERVAÇÃO DO PATRIMÔNIO MODERNISTA E SUA ADAPTAÇÃO A VALORES CONTEMPORÂNEOS}

Adriana Nunes de Alencar Souza ${ }^{1}$

Dayodara Teixeira Reis ${ }^{2}$

Letícia Pires Ferreira $^{3}$

Sávio Tadeu Guimarães 4

\section{RESUMO}

Na busca por melhor compreensão do objeto analisado, a cidade de Brasília, o artigo focalizou um de seus dilemas, estabelecido entre a preservação de valores caros aos ideais modernistas que a conformaram e demandas por inovações ou adaptações em razão das carências com o tempo constatadas em tais projetos ou de novos valores emergentes na contemporaneidade que justificam reflexões e estudos sobre a temática. Sob tal objetivo, o presente artigo se inicia por um breve contexto histórico do Movimento Modernista, que marcou, uma época de ruptura com as tradições e de mudança de valores na primeira metade do século XX. Diante de numerosas carências constatadas em Brasília, o artigo evidencia algumas dessas questões a partir da vivência cotidiana na cidade e de uma base bibliográfica e documental já produzida sobre a mesma. Utilizando, como método de análise, justamente as escalas ou áreas definidoras do Plano Piloto de Brasília. Em ensaios controversos, Loos elaborou o seu próprio estilo arquitetônico com formas adaptadas à época, funcionais, simples e sem decoração. Condenava o ornamento e tudo o que não pudesse ser explicado por uma razão funcional (LUPFER et al., 2003). Outros importantes e influentes arquitetos modernistas nesse período, como Le Corbusier e Mies van der Rohe, tiveram suas ideias como reflexo da obra de Loos. Corbusier, por outro lado, embasado na razão pragmática, encontra uma abertura estética em tudo o que respeita ao arranjo urbano nas "formas eternas da geometria pura", que não decorre única e logicamente da função, demonstrando estar "cheias

\footnotetext{
${ }^{1}$ Centro Universitário de Brasília / adriana.alencares@gmail.com

${ }^{2}$ Centro Universitário de Brasília / dayodara@hotmail.com

3 Centro Universitário de Brasília / arq.leticiapires@gmail.com

4 Centro Universitário de Brasília / savio.guimaraes@ceub.edu.br
} 
de poesia" (1922 apud LUPFER et al. 2003, p. 698). O modernismo funcionalista preconizado no CIAM tornou-se uma referência. Da Carta de Atenas de $1943 \mathrm{em}$ diante, foram dez encontros, entre os anos de 1928 a 1956, que trataram dentre outras coisas do "habitat mínimo, a cidade funcional, o edifício racional, o núcleo urbano da cidade e o habitat coletivo". O objetivo de Le Corbusier era dar à arquitetura um sentido real, social e econômico e estabelecer os limites dos seus estudos (COLIN, 2010). Levantaram-se feitas diversas críticas, propostas e alternativas ao pensamento racional funcionalista surgidas a partir dos anos $1950 \mathrm{e}$ 1960. Por exemplo Jencks (2003, p. 31), ao se elaborar um quadro comparativo dos movimentos arquitetônicos é possível perceber uma correlação a evolução das espécies animais como elas evoluem e se desenvolvem ou regridem dentro de um inter-relacionamento e triunfam. O modernismo seria o maior responsável pela decadência das cidades (JENCKS, 1939, p. 804). "A análise das cidades uso por uso tornou-se um recurso costumeiro do planejamento urbano". Para real compreensão da dimensão global das cidades é fundamental se esmerar no entendimento das combinações e misturas de seus usos conforme Jacobs (2011, p. 157-158). As cidades para a autora são, assim como, as ciências biológicas problemas de complexidade organizada e que caso entendido acha-se a explicação para tudo, pois todas as variáveis estão “inter-relacionadas num todo orgânico". Segundo Farr (2013), para contrapor os pensamentos que prevaleceram com a ascendência da formação arquitetônica modernista, um grupo de arquitetos cria em 1993, o Congresso para o Novo Urbanismo, que trabalha na interface entre a Arquitetura e o desenho urbano, o planejamento e a gestão do meio ambiente, com o objetivo de contribuir para uma melhor qualidade de vida, propondo a diversidade de classes sociais, a sustentabilidade, a permeabilidade do solo e privilegiando o pedestre ao carro. No mesmo ano, foi criado o U. S. Green Building Council (USGBC), o movimento das construções sustentáveis, decorrente da crise do petróleo e inspirado na Cúpula da Terra do Rio de Janeiro, que buscava a adoção de práticas de edificação ambiental ou sustentável, com alta economia de energia. Em 1995, a preocupação com relação a urbanização dispersa, faz surgir uma nova visão, denominada Crescimento Urbano Inteligente (Smarth Growth), que conforme Farr (2013), teve suas raízes no movimento ambiental dos anos 1970. A unificação destes três movimentos de reforma do final do século XX, resulta no urbanismo sustentável, que ressalta os benefícios da integração dos sistemas humanos e naturais, segundo Farr (2013). A primeira cidade projetada aos moldes urbanísticos do CIAM, Brasília, foi inaugurada em 21 de abril de 1960. Foi em 1922, o decreto de 7 de setembro determinava que fosse lançada a pedra fundamental da futura capital, e Planaltina foi o palco escolhido para receber a Comissão Cruls, em missão que buscava o espaço para implantar a nova capital do país, e abrigar a pedra fundamental de Brasília. Portanto, o que se percebe é que apesar de ser uma cidade moderna, a história da criação de Brasília data de muito antes, de um período colonial, ao qual já se têm por costume, 
nos dias de hoje, preservar, por sua importância histórica, cultural, artística, dentre outras. Desde a proposta em 1957 até a sua implantação três anos depois, Brasília deve ser analisada atenciosamente "como mais um exemplo (ou consequência) do gigantesco processo de urbanização brasileiro, caracterizado (...) pela concentração de população nos centros urbanos e pela criação e construção de novas cidades (praticamente do zero)" (SCHLEE, 2006, p. 141-142). Vinte e seis projetos concorreram ao concurso de ideias, como afirma Schlee (2006, p.208) "com um programa bastante vago". O edital que recomendava apenas uma população de 500 mil habitantes para a nova capital e uma indisponibilidade territorial próximo ao lago artificial, não disponibilizando qualquer estudo geográfico. Niemeyer, solicitado por Juscelino Kubitschek, em função de uma parceria de sucesso com a Pampulha, optou por desenvolver apenas o projeto arquitetônico para a nova capital do país, e compôs a comissão julgadora do concurso que nomeou Lucio Costa para tal função. $\mathrm{Na}$ memória justificativa, Lucio Costa buscou 'naturalizar' o seu projeto e descontextualiza-lo da corrente de urbanismo moderno à qual estava claramente filiado. Iniciou pedindo desculpas, alegando que não pretendia concorrer, mas que a solução lhe surgiu pronta, portanto, óbvia e natural. (CAVALCANTI, 2006, p. 211). Em depoimento dado em 1989, Oscar Niemeyer, afirmou: "Uma pessoa pode até não gostar de um projeto meu, mas não consegue ficar indiferente: a arquitetura deve surpreender e criar emoções. O que nos ficou do Egito não foram as casas do dia-adia, mas as grandes realizações" (NIEMEYER, 1989 apud CAVALCANTI, 2006, p. 226). Inscrita como patrimônio da humanidade pela Unesco, Brasília representa o único exemplo, em sua escala, de uma completa cidade modernista. Essa cidade tão nova conforme Costa (1995, p. 298) "esse mourejar, essa dedicação, esse esforço esta criação tirada do vazio num gesto de mágica -, é obra de loucos”. A nova capital foi assim concebida abolindo a farsa da "austeridade", mas procurando ser berço da arte, "conferindo ao brado histórico de 1822" novo significado "industrialização ou morte! ", "não se exporta apenas café, açúcar, cacau" e sim cultura universal. Gehl (2015, p. 197) afirma que "a cidade é uma catástrofe ao nível dos olhos", com urbanismo planejado do alto e de fora, que prioriza os edifícios, os espaços, e por último, a vida. No que ele chama de síndrome de Brasília, consequência do modelo modernista, que negligencia a dimensão humana. Uma resposta óbvia e imediata poderia ser: térreos atraentes". A desertificação dos espaços públicos abertos de uso comum é um dos traços mais típicos da cidade moderna. A paisagem humana foi descuidada, como resultado direto da prioridade dada ao tráfego de veículos. Holanda (2010, p.106) descreve sobre a escala gregária: O centro de Brasília é um "arquipélago". Setores comercial, bancário, hoteleiro, hospitalar etc. são isolados entre si por vários fatores - diferenças de nível de via de serviço, parques de estacionamento periféricos, áreas verdes. Descontinuidades dificultam a apropriação, principalmente para o pedestre. Não há percursos estimulantes ao longo de fachadas contínuas com entradas para o interior dos edifícios. Bioclimaticamente, é 
desconfortável para caminhar. Na escala monumental, faltou construir os edifícios que interligariam os blocos dos ministérios, que seriam destinados ao uso comercial e de serviço, que complementaria a atividade principal da área e traria diversas vantagens à cidade e aos usuários, o espaço ganharia em definição, haveria incentivo ao uso, à permanência no local, toda a Esplanada ganharia em urbanidade e se aproximaria aos Champs Élysées idealizado por Lúcio Costa. Na escala residencial, com influência das cidades europeias tradicionais, houve sabedoria, porém por diversos fatores, como apropriação indevida dos espaços, proliferam barreiras que dificultam o fluxo de passagem de pedestres ou ciclistas; os espaços internos da quadra são muito similares, dificultando a legibilidade e a acessibilidade é ruim, devido a configuração das ruas. Problemas que poderiam ter sido evitados, se tivessem respeitado as orientações do projeto. Por fim, na escala bucólica, que faz a transição entre cidade e campo, os problemas praticamente se concentram na orla do lago e são consequência da sua segregação, da forma de ocupação, do ineficiente monitoramento governamental da configuração e do uso dos espaços. Para atender a demanda intensa por lazer e garantir o livre acesso, a solução seria transformar os espaços remanescentes de suas margens, em grandes parques.

Palavras-chave: Descontinuidade; Patrimônio; Adaptação.

\section{REFERÊNCIAS}

CAVALCANTI, Lauro. Moderno e brasileiro: a história de uma nova linguagem na arquitetura (1930-60). Rio de Janeiro: J. Zahar, 2006.

COSTA, Lúcio. Registros de uma vivência. São Paulo: Empresa das Artes,1995.

COLIN, Silvio. O movimento moderno na academia. 2010. Disponível em: $<$ https://coisasdaarquitetura.wordpress.com/2010/07/28/ciam-o-movimentomoderno-na-academia/>. Acesso em: 15 jun.2017.

FARR, Douglas. Urbanismo sustentável: desenho urbano com a natureza. Porto Alegre: Bookman, 2013.

GEHL, Jan. Cidade para pessoas. São Paulo: Perspectiva, 2015.

HOLANDA, Frederico de. Brasília: cidade moderna, cidade eterna. Brasília: FAUNB, 2010.

JACOBS, Jane. Morte e vida de grandes cidades. 3. ed. São Paulo: WMF M. Fontes, 2011. 
JENCKS, Charles. Movimentos modernos em arquitectura. São Paulo: Edições 70 Almedina, 2006.

LUPFER, Gilbert; PAUL, Jurgen; SIGEL, Paul. Século XX. In: Teoria da arquitetura do renascimento até aos nossos dias. Trad. Maria do Rosário Paiva Boléo. Köln: Taschen, 2003. p. 654-823.

SCHLEE, Andrey Rosenthal. A preservação do moderno: o caso de Brasília. In: PESSÔA, José. Moderno e nacional. Niterói: EdUFF, 2006. p. 141-155. 


\title{
EFICIÊNCIA ENERGÉTICA EM EDIFÍCIOS PÚBLICOS: ADOÇÃO DE CRITÉRIOS DE SUSTENTABILIDADE PARA FISCALIZAÇ̃̃OO PÚBLICA
}

\author{
Letícia Pires Ferreira ${ }^{1}$ \\ Gustavo Alexandre Cardoso Cantuária ${ }^{2}$
}

\section{RESUMO}

Esta pesquisa tem como premissa apresentar diretrizes para implementação de uma cultura sustentável nas edificações públicas, principalmente no que diz respeito a eficiência energética nas instalações prediais. A eficiência energética é baseada em um conjunto de práticas e políticas, que reduzem os gastos com energia e/ou aumente a quantidade de energia oferecida sem alteração da geração. (NUNES, 2010). Estima-se que uma edificação com um projeto eficiente tem potencial de economizar $50 \%$ de energia elétrica, enquanto que as edificações construídas que passem por um retrofit podem atingir 30\% de economia, desde que haja a manutenção correta, de acordo com Roaf (2009). Lamberts (2004) retrata que o desperdício de energia para obtenção de conforto ambiental, está relacionado à falhas nos projetos, que não incorporam os avanços ocorridos em termos de arquitetura bioclimática, materiais e tecnologias construtivas. $\mathrm{O}$ setor público representa aproximadamente $8 \%$ do consumo de eletricidade, o que simboliza uma parcela significativa no consumo de energia elétrica do país. Buscando diminuir os impactos que as obras públicas podem potencializar, a Administração Pública vem procurando promover a institucionalização das ações de sustentabilidade. Santos e Barki (2011) dizem que apesar de não haver definição legal de licitação sustentável, que é uma expressão cunhada doutrinariamente, há leis federais, decretos estaduais e, inclusive, Instrução Normativa do Ministério do Planejamento, Orçamento e Gestão disciplinando sua aplicabilidade. O ordenamento jurídico brasileiro contempla em seu bojo diversas normas legais que amparam o uso da sustentabilidade na Administração Pública. Destaca-se a Lei 12.187/2009 acerca da Política Nacional sobre Mudança do Clima - PNMC que prevê critérios de preferência nas licitações públicas para propostas que propiciem maior economia de energia, água e outros recursos naturais. Para nortear os projetistas e gestores públicos, existem vários modelos de certificação ambiental para edificações que

\footnotetext{
${ }^{1}$ Centro Universitário de Brasília / arq.leticiapires@gmail.com

${ }^{2}$ Centro Universitário de Brasília / gustavo.cantuaria@ceub.edu.br
} 
estabelecem parâmetros fundamentados nas condições climáticas de cada país ou região, que corroboram no sentido de atingir um patamar de eficiência em todos os níveis da construção. “A certificação como processo é importante, pois proporciona uma agenda de soluções aplicáveis à obra, agrega valor de mercado, diminui o consumo geral de insumos e, por fim, legitima e valida os processos de construção sustentáveis." Segundo Viggiano (2012, apud CASADO; FUJIHARA, 2009). No Brasil têm sido utilizados vários modelos, entre eles o Programa Nacional de Eficiência Energética em Edificações (Procel Edifica), modelo autenticamente brasileiro, que através do Instituto Nacional de Metrologia, Qualidade e Tecnologia (Inmetro) e do Laboratório de Eficiência Energética em Edificações (LabEEE), instituiu a Etiqueta Nacional de Conservação de Energia (ENCE), que visa a redução da demanda e do consumo dos sistemas elétricos das instalações prediais públicas, para combater seu desperdício e estimular o uso eficiente e racional de energia elétrica. Desde 1997, foi instituído, pela ELETROBRAS/PROCEL, o Programa Nacional de Eficiência Energética nos Prédios Públicos Procel EPP, a fim de promover ações de economia de energia nos edifícios públicos, nos níveis federal, estadual e municipal. Em 04 de junho de 2014, foi publicada a Instrução normativa (IN) $\mathrm{N}^{0} 02$, que "dispõe sobre o uso da Etiqueta Nacional de Conservação de Energia (ENCE) nos projetos e respectivas edificações públicas federais novas ou que recebam retrofit", fazendo com que a etiquetagem tornasse compulsória para edificações públicas federais desde essa data. E através do Plano Nacional de Eficiência Energética (PNEf), ficou estabelecido no calendário, a obrigatoriedade do PBE Edifica para prédios públicos, até 2020. Na esfera distrital, em 20 de outubro de 2016, o GDF publicou no DODF, o DECRETO No 37.717, que cria o programa de estímulo ao uso de Energia Solar Fotovoltaica no Distrito Federal - Programa Brasília Solar. Tendo em vista, todas estas colocações, este estudo tem como objetivos específicos: investigar o desempenho energético dos edifícios que compõem o Tribunal de Contas do Distrito Federal, objeto central deste estudo, por meio da aplicação das diretrizes do método de classificação do nível de eficiência energética do manual RTQ-C (Regulamento Técnico da Qualidade para o Nível de Eficiência Energética de Edifícios Comerciais, de Serviços e Públicos) do sistema de etiquetagem do Programa Nacional de Eficiência Energética em Edificações (Procel Edifica); analisar os dados obtidos com o intuito de se chegar a um diagnóstico das potencialidades e falhas das edificações estudadas, em seguida, estabelecer um parâmetro entre as edificações, indicando os pontos positivos e negativos de cada uma de acordo com a realidade bioclimática de Brasília e também, propor melhorias para cada edificação, com a indicação de diretrizes para obtenção de um bom nível de eficiência energética, com a possibilidade de obtenção do Selo Procel. Já o objetivo geral é elaborar um instrumento (manual ou cartilha), que contenha essas diretrizes para obtenção de um bom nível de eficiência energética. Sabe-se que um aproveitamento adequado das condições climáticas locais, através de decisões de 
projetos, proporciona um bom resultado em termos de arquitetura. "O potencial do clima local para a ventilação natural tem sido grandemente subutilizado, apesar de que muito contribuiria para a redução do consumo de energia" (ROMERO, 2011, p.71). A aplicação da Etiqueta PBE Edifica visa determinar o potencial de economia de energia de uma edificação, ou seja, o seu nível de eficiência energética, que é avaliado pela aplicação do RTQ-C, que apresenta os critérios para classificação do edifício através de classificações parciais da envoltória, do sistema de iluminação e do sistema de condicionamento de ar (LAMBERTS et al., 2010). Há dois métodos de classificação do nível de eficiência energética: método prescritivo e de simulação. $\mathrm{O}$ primeiro se dá através da aplicação de uma equação fornecida, válida para edifícios condicionados. No segundo, usa-se o método prescritivo e a simulação do desempenho termo-energético de edifícios condicionados e não condicionados. $\mathrm{O}$ processo de etiquetagem é composto de duas etapas, inspeção de projeto, que pode ser feita seguindo os dois métodos e inspeção da edificação construída, que é feita através da inspeção amostral in loco. Pode ser emitida uma etiqueta para o edifício completo ou para parte deste. Ela é dita parcial quando referente à envoltória ou combinando a envoltória com um dos outros dois sistemas - iluminação ou condicionamento de ar. A Etiqueta PBE Edifica classifica o desempenho da eficiência energética dos edifícios de A (mais eficiente) a $\mathrm{E}$ (menos eficiente). Segundo o RTQC, há avaliação de pré-requisitos para cada dimensão avaliada e bonificações, em função de estruturas e ações que contribuam para o desempenho eficiente da edificação. Com base em pesquisa bibliográfica e de acordo com os critérios estabelecidos no método de classificação do nível de eficiência energética do manual RTQ-C, serão realizados estudos de caso, visando estabelecer as diretrizes que irão compor a matriz a ser desenvolvida, que irá compor o manual e/ou cartilha, que será o objeto resultante deste estudo e que almeja-se que seja aplicada na elaboração de projetos novos e retrofit para eficiência energética servindo assim, de guia para nortear as ações de implementação de melhorias e/ou reabilitação de edifícios públicos.

Palavras-chave: Eficiência Energética; Certificação; Fiscalização; Edifícios Públicos.

\section{REFERÊNCIAS}

\section{LAMBERTS, Roberto; DUTRA, Luciano; Pereira, Fernando O. R. Eficiência} energética na arquitetura. São Paulo: Prolivros, 2004.

LAMBERTS, R. et al. Etiquetagem de eficiência energética de edificações. 2010.

NUNES, A. L. R. Eficiência energética em prédios públicos: projeto de diplomação de graduação em engenharia elétrica. Porto alegre: Universidade Federal do Rio Grande do Sul, 2010. 
ROAF, S. A adaptação de edificações e cidades às mudanças climáticas. Porto Alegre: Bookman, 2009.

SANTOS, Murillo Giordan; BARKI, Teresa Villac Pinheiro (Coord.). Licitações e contratações públicas sustentáveis. Belo Horizonte: Fórum, 2011.

ROMERO, M. A. B. Arquitetura do lugar: uma visão bioclimática da sustentabilidade em Brasília. São Paulo: Nova Técnica Editorial, 2011.

VIGGIANO, M. H. S. Edifícios púbicos sustentáveis. 3. ed. rev. Brasília:

Subsecretaria de Edições Técnicas, 2012. 


\section{ENSINO DO DESENHO E SISTEMA CONSTRUTIVO DA HABITAÇÃO POPULAR POR MEIO DE VIDEOAULAS}

Ricardo Cesar Machado ${ }^{1}$

Eliete de Pinho Araujo²

\section{RESUMO}

O que deve ser feito? Para responder a questão uma história [...] Videoaulas é um projeto de uma vida! No mestrado desde 2012 [...] Em 2007, objeto de monografia final em Comunicação e Marketing [...] Investigações acerca de Docência Universitária remontam desde o ano 2000 [...] Pesquisas arquitetônicas originam-se de 1991 [...] As questões audiovisuais são desde 1980 [...] E por aí vai! [...] E qual o motivo para este relato?! Para declarar que apesar de tanto tempo na investigação deste assunto, segue-se mudando [...] E mudando [...] E mudando as ideias pertinentes a ele! A impressão que se tem é que cada vez sabe-se menos! Então de que vale fazer tudo isto? Vale para seguir caminhando! Isto é muito importante para construção do conhecimento! Intenta-se mesclar arquitetura, educação e audiovisual num "sobrevoo" divertido e educativo sobre Habitação Popular, seu desenho e sistemas construtivos com apreço cultural, ambiental, tecnológico e regional. A questão que leva a pesquisa é a omissão do reconhecimento acadêmico das características que atendam à habitação popular e suas especificidades, bem como, a ausência da sistematização por meio audiovisual da instrução do desenho e sistemas construtivos do morar humilde. Aspirar modos e didática audiovisual para o aprendizado deste tema. Investigar sistemas construtivos. Sistematizar a cessão de conteúdos de arquitetura em imagens, sons e dramaticidade. Educar e entreter. Fixar conhecimento. Para tentar chegar perto dos objetivos pretendem-se alguns procedimentos. Pesquisar a filosofia de casas do século XX por meio da herança deste período, assunto presente no relato desapossado de preconceitos e identificadores profissionais do Livro de Iñaki Ábalos, Boa-Vida (2001). Por meio de pesquisa bibliográfica anotar a diversidade conceitual de residências e respectivas

\footnotetext{
${ }^{1}$ Centro Universitário de Brasília / Ricardo.machado@ceub.edu.br

${ }^{2}$ UniCEUB /Prof. ${ }^{a}$. Dr a , Brasília DF Brasil

Curso de Arquitetura e Urbanismo-FATECS/ eliete.araujo@ceub.edu.br
} 
correntes de pensamentos deste autor, ou seja, suas filosofias, bem como, verificar o deleite de planejar, refletir e viver intensamente a casa para, posteriormente, aplicar os conceitos na futura proposição do desenho da casa humilde. Rastrear habitações populares por meio da análise de sistemas construtivos e exemplos das principais regiões brasileiras. Intenta-se investigar a propriedade da vida humana, bem como, suas peripécias em busca da adequação às diversas condições nos meios habitáveis do Brasil, estes por vezes inóspitas. Assim, lança-se mão de pesquisa bibliográfica, especificamente, do livro Arquitetura popular brasileira, de Günter Weimer (2005), notadamente do capítulo I, Como mora o povo brasileiro, e também, do capítulo VII, As técnicas construtivas. Espera-se, com esta atitude, examinar concisamente a heterogeneidade das acomodações que os habitantes populares brasileiros conseguiram realizar durante a sua história. Lançar mão da experiência universitária em elaboração audiovisual similar a proposta desta dissertação, adquirida na realização e distribuição do filme de curta metragem denominado Porcus Píritus. Bem como, o seu poder educativo junto aos alunos de arquitetura do UniCEUB. Onde, a partir do enfrentamento de situação problema vivenciado por veteranos, os quais exigiam solução para o comportamento inadequado de calouros em ateliê/laboratório acadêmico, isto, por meio de maneira inusitada em audiovisual, briefing, realizou-se planejamento fílmico perante a demanda por meio de pesquisas qualitativas, quantitativas e bibliográficas. A análise deste caso (presente no artigo "Poder e Cinema no Ensino de Arquitetura", do autor desta dissertação e Porcus Píritus) confirmou o audiovisual e seu posicionamento, benefícios, alcance, promessa, conceito criativo como solução viral para a educação, portanto, possuidor de poder de mudança de comportamento estudantil pela audiência do curta metragem. Aferiu-se que a educação solicitada pelos veteranos de arquitetura do UniCEUB foi alcançada por meio de mídia audiovisual. Realizar pesquisas quantitativas e qualitativas com estudantes. Com a intensão de dar o primeiro impulso nesta investigação teórico-empírica iniciaram-se as pesquisas quantitativas para levantar alguns dados estatísticos. Isto para que num futuro próximo possam ser realizadas outras pesquisas, desta feita, qualitativas, de maneira a embasar melhor este assunto, e quem sabe, compreendê-lo. Após análise das informações contidas na pesquisa exploratória elaborou-se um questionário estruturado, com a seleção de perguntas que se aproximassem da revelação de um dos aspectos do problema: a ideia audiovisual. Por questões de limitação de pessoal, o grupo deste trabalho de pesquisa foi composto por um único integrante, o autor da dissertação. Numa amostragem de 115 (cento e quinze) pessoas entre homens e mulheres nos semestres dos anos de 2012 a 2015, por meio de abordagem corpo-a-corpo, investigou-se o público constituído pelos estudantes de arquitetura e engenharia do UniCEUB. Esta pesquisa teve como intenção conhecer a opinião desta amostragem universitária, jovens entre 18 e 24 anos, todos residentes no Plano Piloto do Distrito Federal. A pesquisa quantitativa obteve resultado prévio acerca da constatação do que é 
determinante para se alcançar um produto audiovisual que agrade aquele target. A pesquisa quantitativa também descobriu que, com relação ao público alvo, quais gêneros de obra audiovisual tem possibilidade de alcançar sucesso. Inferiu-se preliminarmente que para aproximar o planejamento de videoaula didática sem tédio, porém, com aparência e sedução fictícia e, assim, pactuar educação, prazer e satisfação para o público alvo, estudantes de arquitetura e engenharia, a combinação audiovisual mais adequada seria: a idealização de uma história com roteiro laborado arduamente e composto pelo seguinte mix de gêneros: prioritariamente a comédia, seguido por ação envolta de aventura e romance. Aquisição de édito arquitetônico/audiovisual para ensinar o desenho e sistemas construtivos da morada popular será consentida por meio da: planificação de produto audiovisual educativo/ficcional em forma seriada.

Palavras-chave: Ensino; Desenho; Habitação; Videoaulas.

\section{REFERÊNCIAS}

ÁBALOS, Iñaki. A Boa-vida: Visita guiada ás casas da modernidade. Barcelona. G. Gilli, 2003.

DUARTE, Rosália. Cinema e educação. Belo Horizonte: Autêntica, 2002.

EASTMAN, Chuck et al. Manual de BIM: um guia de modelagem da informação da construção para arquitetos, engenheiros, gerentes, construtores e incorporadores. Porto Alegre: Bookman, 2014.

ECO, Umberto. Como se faz uma tese em Ciências Sociais. Lisboa: Presença, 2007.

FERRÉS, J. Vídeo e educação. Porto Alegre: Artes Médicas Sul, 1996.

MIRANDA, C. E. A. A Educação do Olho. Cadernos CEDES, Campinas, SP, n. 54, 2005.

NUNES, Edson de Oliveira (Org.). A aventura sociológica, obejetividade, paixão, improviso e método na pesquisa social. Rio de Janeiro: Zahar Editores, 1978.

RODRIGUES, Chris. O Cinema e a produção. Rio de Janeiro: FAPERJ, 2005.

WEIMER, Günter. Arquitetura popular brasileira. São Paulo: M. Fontes, 2005. 


\section{ENTRE A PRESERVAÇÃO E A INTERVENÇÃO: DISCUTINDO A COMPLEXIDADE E OS DESAFIOS PARA BRASÍLIA - DF}

Dayodara Teixeira Reis ${ }^{1}$

Adriana Nunes de Alencar Souza ${ }^{2}$

Letícia Pires Ferreira ${ }^{3}$

Sávio Tadeu Guimarães ${ }^{4}$

\section{RESUMO}

$\mathrm{Na}$ busca por melhor compreensão do objeto aqui analisado, a cidade de Brasília, o resumo aqui proposto focaliza um de seus dilemas, estabelecido entre a preservação de valores caros aos ideais modernistas que a conformaram e demandas por inovações ou adaptações. De maneira geral, tais dilemas têm sido constatados em razão das carências com o tempo observadas em tais projetos ou de novos valores emergentes na contemporaneidade que justificam reflexões e estudos sobre a temática. Para melhor elucidar a problematização então emergente sobre os postulados modernistas, e dentro do próprio campo, como no caso das autocríticas proferidas na décima edição do Congresso Internacional de Arquitetura Moderna, realizada em 1954, tomemos por referência algumas considerações então enunciadas por nomes de campos de atuação distintos. Trabalhos como os de Maurice Halbwachs (1990), Jane Jacobs (2011) e Charles Jencks (2006), estão entre essas bases críticas de campos diversos que, respectivamente, evidenciaram, entre os anos $1950 \mathrm{e}$ 1970, a força da memória agregada aos espaços, assim como a necessária permeabilidade de usos e acessos aos espaços da cidade e as várias alternativas espaciais então emergentes. Para bem compreender a influência que exercem os diversos lugares de uma cidade sobre os grupos que a ela se adaptaram lentamente, seria necessário, numa grande cidade moderna, observar sobretudo os quarteirões antigos, ou as regiões relativamente isoladas de onde seus habitantes não se afastam, a não ser para ir ao trabalho, e que formam como pequenos mundos fechados, ou ainda, mesmo nas partes novas da cidade, as ruas e as avenidas povoadas sobretudo

\footnotetext{
${ }^{1}$ Centro Universitário de Brasília / dayodara@hotmail.com

${ }^{2}$ Centro Universitário de Brasília / adriana.alencares@gamil.com

${ }^{3}$ Centro Universitário de Brasília / arq.leticiapires@gmail.com

${ }^{4}$ Centro Universitário de Brasília / savio.guimaraes@ceub.edu.br
} 
de operários e onde estes se encontram em casa, porque entre a casa e a rua há trocas permanentes e porque as relações de vizinhança ali se multiplicam (HALBWACHS, 1990, p. 131-144). Dividindo os usos da cidade por categorias cria-se uma armadilha, método esse utilizados pelos modernistas ao setorizarem as diferentes funções que as áreas de uma cidade podem apresentar. Contudo, "a análise das cidades uso por uso - tornou-se um recurso costumeiro do planejamento urbano". Para real compreensão da dimensão global das cidades é fundamental se esmerar no entendimento das combinações e misturas de seus usos conforme Jacobs (2011, p.157-158). De acordo com Jencks (2014, p. 804-812) a arquitetura moderna teve seu fim em uma data marcada, qual seja, a demolição do conjunto habitacional PruittIgoe em 15 de junho de 1972 às 15h 32m. O modernismo seria o maior responsável pela decadência das cidades, já o pós-modernismo com novos programas arquitetônicos e urbanistas representariam a "responsabilidade natural de uma cultura de possibilidades de escolha” (JENCKS, 1939, p. 804). Inaugurada em 1960, a cidade de Brasília, projeto urbanístico de Lúcio Costa peculiarizado pelas obras arquitetônicas de Oscar Niemeyer, é aqui apresentada sob o conceito de "escala" adotado pelo urbanista como característica elementar do célebre Plano Piloto da cidade. Esse conjunto de escalas ou categorias espaciais utilizadas por Lúcio Costa ao tematizar e setorizar a espacialidade urbana do plano da capital federal e que foi por ele subdividido em quatro escalas - escala monumental, residencial, gregária e bucólica - tornou-se, por tal importância na configuração morfológica da cidade. Esse conjunto de escalas foi escolhido, não por acaso, como a referência das diretrizes de tombamento do plano na esfera nacional pela Secretaria do Patrimônio Histórico e Artístico Nacional (SPHAN), cinco anos após o tombamento do mesmo como Patrimônio Cultural do Distrito Federal pelo governado local e como Patrimônio Cultural da Humanidade pela Organização das Nações Unidas para a Educação, a Ciência e a Cultura (UNESCO), ambos em 1987. Nesse mesmo ano, Lúcio Costa define as diretrizes para o desenvolvimento de Brasília através do documento Brasília Revisitada, apresentando ao Governador José Aparecido de Oliveira, tratava da Preservação, Complementação, Adensamento e Expansão Urbana de Brasília. Ressaltou, que o importante era o respeito as quatro escalas, a manutenção da estrutura urbana que por vez tem função de estabelecer as escalas, o respeito na manutenção dos dois eixos originais e seus cruzamentos, e principalmente, a preservação do conjunto formado pelo eixo monumental, “... serena e digna obra-prima de integração arquitetônico-urbanística" (COSTA, 199099). É fato que a capital federal do Brasil representa o único exemplo, em sua escala, de uma completa cidade modernista. Desse modo, independentemente de sua espacialidade arquitetônica e urbanística poder ser, por muitos, bem assimilada e, por vários, questionada, a importância da cidade se reforça, sem sombra de dúvidas, quando atribuída à sua dimensão histórica. De fato, independente das críticas que se faça hoje a preceitos modernistas cristalizados em sua espacialidade, torna-se 
possível, por meio da preservação de tal espacialidade, a salvaguarda do momento histórico por ela representado quando de sua construção. Contudo, analisando o caso específico representado por Brasília, apesar de ser importante considerar a preservação da arquitetura moderna por questões estéticas ou históricas, é preciso evidenciar outras de suas dimensões. Sob essa abordagem mais ampla da cidade, ressalta-se o fato de diversos problemas constatados na cidade poderem ser atrelados ao seu projeto, ao que foi efetivamente construído, à mudança na implantação inicialmente prevista, ao grande afluxo e permanência local não previsto, a forte segregação socioespacial engendrada na cidade, entre outros fatores. E juntos, tais fatores ampliam as contradições da cidade, assim como ressaltam críticas em relação ao seu tombamento, tanto no que diz respeito às específicas diretrizes elencadas para sua preservação quanto no que se relaciona às necessidades e desejos de mudanças inerentes na espacialidade de qualquer cidade - crescentemente assimiladas como um organismo vivo. Conforme evidenciado por vários estudiosos e responsáveis pela gestão do Plano Piloto elaborado por Lúcio Costa, a espacialidade por ele concebida se reveste de caráter e unidade. Contudo, mesmo para alguns desses críticos, a urbanidade contemporânea ou pós-moderna demanda ajustes e inovações previamente estudadas. Alguns dos críticos mais ferrenhos da cidade, e/ou das premissas modernistas, explicitam a pouca atenção dada à dimensão humana na cidade, negligência esta, de fato, presente em muitas das intervenções empreendidas sob o ideário da máquina que pautou o imaginário e as ações de artistas, arquitetos e urbanistas entre fins do século XIX e meados do século XX. De fato, conforme enfatizado em trabalhos atuais como o organizado por Karssenberg (2015) com a participação de mais de 80 planejadores de todo o mundo e, tal como já enunciava Kevin Lynch (1997, p. 123) logo após o enfraquecimento da linguagem racional funcionalista, pouco após a construção de Brasília, "a cidade não é construída para uma pessoa, mas para um grande número delas, todas com grande diversidade de formação, temperamento, ocupação e classe social". E para minimizar os problemas constatados, decorrentes não apenas do modelo modernista, mas também do expressivo aumento populacional em Brasília, propostas distintas se somam como tentativas de amenização das carências hoje constatadas não apenas por sociólogos, como os que inicialmente as evidenciaram em todo o mundo, mas também por geógrafos, planejadores urbanos, arquitetos, artistas e cidadãos vinculados às mais diversas áreas de atuação. Destaca-se, entre essas críticas e propostas atuais, uma considerável necessidade de intervenção sobre a espacialidade urbana da cidade no que se refere à prioridade dada aos automóveis, à carência de outros modais de transporte e à dificuldade de acessibilidade entre muitos dos núcleos parcialmente isolados que compõem sua malha espacial. Destacam-se, também, propostas voltadas ao atendimento a vários segmentos sociais de maneira a diminuir a segregação socioespacial existente na cidade e entre a cidade e suas imediações. Contudo, a propostas como essas, de possível aplicação em muitas espacialidades de caráter 
modernista em maior ou menor grau, soma-se a peculiaridade das escalas de Brasília, atributos que conformam o cerne de seu Plano Piloto e aos quais já vem sendo propostas diretrizes de preservação após as primeiras ações de preservação surgidas com o seu tombamento e que consideramos ser uma premissa nas intenções de projetos sobre a cidade, ou seu plano. Pensar as escalas de Brasília como referência aos procedimentos de intervenção na cidade se mostra, de fato, como uma estratégia pertinente e de possível negociação entre os vários interesses atuantes na cidade abrandando, assim, o dilema existente entre as tentativas de preservação da essência espacial da cidade e as propostas de atualização ou adaptação da mesma a demandas atuais.

Palavras-chave: Preservação; Intervenção; Brasília; Escalas.

\section{REFERÊNCIAS}

BRAGA, Milton. O concurso de Brasília: sete projetos para uma capital. São Paulo: Cosac Naify: Imprensa Oficial do Estado, 2010.

BRANDÃO, Vera Bonna. W3 sul, ontem, hoje, amanhã: os dilemas de uma avenida modernista. Disponível em:

http://www.docomomo.org.br/seminario\%208\%20pdfs/189.pdf> Acesso em: 7 dez. 2016.

BRASIL . Portaria 314, de 08 de outubro de 1992. Disponível em:

<http://www.iphan.gov.br/portaria 1992.pdf>. Acesso em: 10 jun. 2017.

BRASIL. Lei no 3.751, de 13 de abril de 1960. Dispõe sôbre a organização administrativa do Distrito Federal. Diário Oficial da União. Disponível em: <http://www.planalto.gov.br/ccivil_03/leis/L3751.htm>. Acesso em: 12 ago. 2017.

CABRAL, Valéria Maria Lopes; MARTINS, Rosanalha; PANITZ, Marília (Org.). Azulejos em Brasília, azulejos em Lisboa = Tile from Brasília, tile fromLisbon.: Athos Bulcão e a tradição de azulejaria barroca. 2013. Disponível em: $<\mathrm{http}$ //www.fundathos.org.br/arquivos/Catálogo Athosmiolo.pdf>. Acesso em: 12 ago. 2017.

CARTA de Brasília. Brasília: 1995. Disponível em: <http://www.iphan.gov.br/cartas/Carta de Brasilia 1995.pdf>. Acesso em: 10 jun. 2017. 
CAVALCANTI, Lauro. Moderno e brasileiro: a história de uma nova linguagem na arquitetura (1930-60). Rio de Janeiro: J. Zahar, 2006.

COSTA, L. Relatório do plano piloto: Brasília, cidade que inventei. Brasília: ArPDF: Codeplan: DePHA, 1991.

COSTA, Lúcio. 1990-1999. Disponível em:

<http://www.jobim.org/lucio/handle/2010.3/2267>. Acesso em: 11 ago. 2017.

COSTA, Lucio. Brasília revisitada 1985/1987: complementação, preservação, adensamento e expansão urbana. 1986. Disponível em: <file://C:/Users/veras/Downloads/BRASÍLIA REVISITADA 1985 1987.pdf>. Acesso em: 12 ago. 2017.

COSTA, Lucio. Lucio Costa: registro de uma vivência. São Paulo: Empresa das Artes, 1995.

DECLARAÇÃO de Estocolmo. Estocolmo: 1972. Disponível em:

$<$ http://www.iphan.gov.br/Declaracao de Estocolmo 1972.pdf>. Acesso em: 10 jun. 2017.

FARR, Douglas. Urbanismo sustentável: desenho urbano com a natureza. Porto Alegre: Bookman, 2013.

FERREIRA, Samara Batista. Turismo cultural sustentável: análise da situação de preservação da Catedral Metropolitana de Brasília. 2005. 109f. Dissertação (Mestrado em Turismo) - Centro Universitário de Brasília, Brasília, 2005.

GALBINSKI, José. Problemas de desenho urbano em Brasília: ruas ou vias e a luta contra a topografia. In: PEIXOTO, Elane Ribeiro et al (Org.) Tempos e escalas da cidade e do urbanismo: Anais do XIII Seminário de História da Cidade e do Urbanismo. Brasília, DF: Universidade Brasília- Faculdade de Arquitetura e Urbanismo, 2014. Disponível em:

$<$ http://www.shcu2014.com.br/content/problemas-desenho-urbano-em-brasiliaruas-ou-vias-e-luta-contra-topografia>. Acesso em: 20 jun. 2017.

GEHL, Jan. Cidade para pessoas. São Paulo: Perspectiva, 2015.

GOUVÊA, Luiz Alberto. Cidade viva: curso de desenho ambiental urbano. São Paulo: Nobel, 2008.

HALBWACHS, Maurice. A memória coletiva. São Paulo: Vértice, 1990. 
HOLANDA, Frederico de. Brasília: cidade moderna, cidade eterna. Brasília: FAUnb, 2010.

HOLANDA, Frederico de. O espaço de exceção. Brasília: UnB, 2002.

HOLSTON, James. A cidade modernista: uma crítica de Brasília e sua utopia. São Paulo: Companhia das Letras, 1993.

JACOBS, Jane. Morte e vida de grandes cidades. São Paulo: M. Fontes, 2011.

JENCKS, Charles. Movimentos modernos em arquitectura. São Paulo: 70, 2006.

KARSSENBERG, Hans. A cidade ao nível dos olhos: lições para os plinths. Porto Alegre: EDIPUCRS, 2015.

LEFEBVRE, Henri. O direito à cidade. São Paulo: Documentos, 2001.

LIMA, Adeildo Viegas. COSTA, Maria Elisa. Brasília 57-85: do plano piloto ao plano piloto. Brasília: TERRACAP/GDF,1985.

MEDEIROS, Ana Elisabete; CAMPOS, Neio. Cidade projetada, construída, tombada e vivenciada: pensando o planejamento urbano em Brasília. In: PAVIANI, Aldo et al (Org.). Brasília 50 anos: da capital a metrópole. Brasília: Universidade de Brasília, 2010. Cap. 2. p. 137-161. (Coleção Brasília).

MENEZES, Marilene Resende de. O Lugar do pedestre no Plano Piloto de Brasília. Ano. 2016 f. Dissertação (Mestrado) - Programa de Pesquisas e Pós-Graduação em Arquitetura e Urbanismo, Universidade de Brasília, Brasília.

OLIVEIRA, Fabiana Carvalho de. Ressignificações das obras de Athos Bulcão nos espaços de Brasília: entre a obra de arte e o ornamento. 2003. 177 f. Dissertação (Mestrado em Arte) - Instituto de Artes, Universidade de Brasília, Brasília, 2003.

ROMERO, Marta Adriana Bustos. A arquitetura bioclimática do espaço público. Brasília: Universidade de Brasília, 2015. (Coleção Arquitetura e Urbanismo).

ROMERO, Marta Adriana Bustos.Arquitetura do lugar. uma visão bioclimática da sustentabilidade em Brasília. São Paulo: Nova Técnica, 2011. 
ROSSETTI, Eduardo Pierrotti. Plano Piloto/Quadras 700: questões para refletir sobre Brasília. Universitas: Arquitetura e Comunicação Social, v. 11, n. 2, p. 1-6, jul./dez. 2001.

SABÓIA, Luciana; DERNTL, Maria Fernanda (Org.). Brasília 50+50: cidade, história e projeto. Brasília: Universidade de Brasília, 2014.

SCHLEE, Andrey Rosenthal. A preservação do moderno: o caso de Brasília. In: PESSÔA, José. Moderno e Nacional. Niterói: UFF, 2006. p. 141-155.

SILVA, Fernando Fernandes da. As cidades brasileiras e o patrimônio cultural da humanidade. São Paulo, USP, 2001.

UNDERWOOD, David. Oscar Niemeyer e o modernismo de formas livres no Brasil. São Paulo: Cosac \&Naify, 2002.

UNITED NATIONS. Brundtland Report Our Common Future. 1987. 


\section{EXISTE RELAÇÃO ENTRE A VIOLÊNCIA E O SISTEMA VIÁRIO?}

Paulo Cesar Galante Siqueira ${ }^{1}$

Paulo Afonso Cavichioli Carmona ${ }^{2}$

\section{RESUMO}

Um dos grandes desafios das cidades é torná-las acessíveis, promovendo a integração entre os bairros. Essa integração passa pelo sistema viário, que permite o trânsito de pessoas entre diversas partes. A integração das partes também favorece o aumento da violência, proporcionando rotas de acesso e fuga para o meliante. Infelizmente o sistema viário não é usado apenas pelos cidadãos de bem, mas também é usado para o crime. O nível de integração de uma via, que avalia a facilidade com que essa via pode ser acessada, está correlacionado com a violência. Ao projetar-se um bairro ou uma cidade, são estabelecidas hierarquias das vias, mas muitas vezes essas hierarquias são invertidas em função do uso. Um estudo pósocupação de uma residência muitas vezes mostra que o conceito do projeto não foi atendido pelos usuários, da mesma forma isso ocorre nas cidades. A hierarquia das cidades é mudada em função da facilidade com que os caminhos são estabelecidos. Para compreender-se essa hierarquia, é necessário o estudo do nível de integração dos espaços. Ao se estabelecer uma relação entre o nível de integração do sistema viário e a ocorrência de crimes, deve-se atentar para pelo menos duas formas de crime. Os crimes de oportunidade, onde a vítima quase sempre é o pedestre, normalmente ocorrem em centros mais integrados. O meliante geralmente escolhe a vítima ao acaso, sendo necessárias grandes concentrações, pois o criminoso usa o mesmo sistema de transporte que a vítima. Existem também os homicídios, onde o marginal possui seu próprio meio de transporte e deseja evitar grandes concentrações. Assim, pode-se estabelecer que os crimes de oportunidade ocorrem em lugares onde as vias são mais integradas, e os homicídios ocorrem em vias menos integradas. Este fato fica claro ao comparar-se a ocorrência dos crimes em áreas

\footnotetext{
${ }^{1}$ UniCEUB, Brasília, DF, Brasil.

Curso de Arquitetura e Urbanismo - FATECS/ pcgalante@gmail.com

${ }^{2}$ UniCEUB /Prof. Dr, Brasília DF Brasil

Faculdade de Direito - paulo.carmona@ceub.edu.br
} 
mais urbanizadas em relação a outras pouco urbanizadas. Em 2009 aconteceram 124 homicídios em Ceilândia, área pouco urbanizada do Distrito Federal, contra 22 no Plano Piloto (Fonte: Secretaria de Segurança Pública do DF, 2009). Essa comparação se torna possível porque os boletins de ocorrência no Distrito Federal são georreferenciados, o que permite uma comparação entre criminalidade e a via. Podese avaliar a proposta de forma analítica, evitando especulações sem fundamento. Pode-se definir o raio de atuação de cada via para que a ocorrência seja associada a ela. Então, é possível determinar a influência do sistema viário e não apenas da via. Após, estabelece-se o mapa de ocorrências, graduando as vias em um sistema de cores, tomando o mapa de axialidade como exemplo. Os mapas podem ser comparados, mostrando a relação da integração da via com a criminalidade. Este processo é feito tanto para os crimes de oportunidade, quanto para os homicídios. Muito se fala e estuda a respeito da Mobilidade Urbana, mas pouco sobre como ela pode influenciar a violência em um local. Quando se promove a integração em uma cidade, melhorando o acesso da população, indiretamente se amplia a criminalidade. A integração é de suma importância para a cidade, mas deve ser feita pensando em todas as implicações. O Sistema Viário pode auxiliar ou prejudicar a segurança. Há muitas diretrizes urbanísticas quando uma cidade é desenvolvida: topografia, infraestrutura, valorização imobiliária. Pouco se pensa nas consequências comportamentais dessas decisões. Os resultados da pesquisa estabelecem diretrizes para auxiliar neste aspecto. A cidade também deve ser alvo de reflexões psicológicas. A configuração do espaço e a maneira com que este é percebido e apropriado pela população, tem impacto direto no comportamento. Pode-se perceber isso nas atitudes de pessoas da mesma cidade, mas que possuem comportamentos diferentes devido ao bairro que moram. Sabe-se que não se pode desprezar fatores como educação e poder aquisitivo, mas não se pode negar que exista um certo determinismo comportamental, que é fruto do meio. A maneira como se ocupa um lugar passa pela forma que este pode ou não ser acessado. A violência está diretamente associada a questões sociais que, por sua vez, estão ligadas à cidade. $\mathrm{O}$ planejamento da cidade deve se preocupar não apenas com o impacto imediato, mas como será a dinâmica da cidade ao longo dos anos. Estas questões permitem a análise comportamental da cidade, permitindo a previsão de tendências no que diz respeito à Segurança Pública. A compreensão deste assunto pode tanto fornecer métodos de diagnóstico das cidades existentes, como auxiliar no projeto de novos bairros e, eventualmente, de cidades. A previsão de tendências de comportamento de uma cidade fica dependente da forma com que um sistema viário é implantado.

Palavras-chave: Sistema Viário; Violência; Crime; Urbanismo; Sintaxe Espacial; Mobilidade Urbana.

\section{REFERÊNCIAS}


MEDEIROS, Valério. Urbis Brasiliae: o labirinto das cidades brasileiras. Brasília: Universidade de Brasília, 2013.

VELOSO, Sérgio; SANTIAGO, Vinícius. Ninguém entra, ninguém sai: mobilidade urbana e direita à cidade no Complexo do Alemão. Rio de Janeiro: Fundação Henrich Böll Brasil, 2017 


\section{FACHADAS DE VIDRO E 0 IMPACTO NO MODERNISMO DE BRASÍLIA}

Laura de Castro Oliveira Guerreiro ${ }^{1}$

André Luiz Primo Bertoletti ${ }^{2}$

Gustavo Alexandre Cardoso Cantuária ${ }^{3}$

\section{RESUMO}

O Plano Piloto de Brasília entende-se como um projeto urbano inteiramente formado pelos princípios modernistas. Prédios com pilotis para maior permeabilidade de pedestres e da própria ventilação, cobogós em fachadas inteiras para melhor configurar o conforto ambiental interno dos prédios e muitos brises de diferentes configurações que protegem as janelas da entrada excessiva do sol e consequentemente do calor intenso. Essas foram algumas das principais abordagens para a concepção dos primeiros edifícios de Brasília em relação ao controle da intensidade do sol, muito severo na região e por fim, para melhorar a qualidade da temperatura interna das moradias, comércio e serviços. Esses aspectos foram, com o tempo, substituídos, em sua maioria, por fachadas com quantidades cada vez maiores de vidro até o revestimento externo ser totalmente coberto por este. A maior parte desses edifícios com fachadas de vidro são compostas por atividades de serviço e comércio. Uma alternativa que poderia ajudar a reduzir o impacto causado por estas fachadas sobre a cidade e ajudar a reduzir gastos seria a instalação de painéis fotovoltaicos para a obtenção de eletricidade. O Distrito Federal possui um período de chuvas curto, sendo que na maior parte do ano a capital é banhada por intensa radiação solar. Esse fator aliado com o fato de que o DF possuí centros urbanos majoritariamente compostos por grandes edificações com fachadas envidraçadas inutilizadas e amplos terraços fortalecem a proposta. Os motivos por trás dessas mudanças são diversos, e entende-los é necessário para a melhor utilização desse revestimento envidraçado ou mesmo substituí-lo por métodos mais eficientes e sustentáveis. A pesquisa tem como objetivo mostrar as consequências da aplicação

\footnotetext{
${ }^{1}$ Centro Universitário de Brasília / laura_guerreiro1@hotmail.com

${ }^{2}$ Centro Universitário de Brasília / andbertoletti@gmail.com

${ }^{3}$ Centro Universitário de Brasília / gustavo.cantuaria@ceub.edu.br
} 
de fachadas inteiramente de vidro, focando no estudo histórico sobre essas escolhas e possíveis formas de solucionar melhor essa problemática. Foram realizados estudos bibliográficos sobre a história de Brasília e as técnicas modernistas utilizadas nos edifícios para se obter um conforto ambiental interno adequado, e com isso desenvolver uma análise acerca da utilização de vidros nas fachadas e uma possível alternativa do uso de tecnologia fotovoltaica. Brasília possui em sua criação os princípios modernistas compostos da ideia de cidade- jardim onde a natureza e a vida no campo, eram transportadas para a vivência na cidade. Lucio Costa precedido de Ebenezer Howard quis transparecer a ideia de uma cidade com o contato direto com a natureza, e qualificar a vida do morador. Nesse sentido o conforto interno da arquitetura deve-se sempre está conversando com o clima e a natureza da região. $\mathrm{O}$ clima foi um importante norteador de toda a arquitetura que viria a compor o plano piloto. Antes do início do concurso para o projeto da capital, foram realizados vastos estudos sobre as condições climáticas de Brasília. Essas explorações deram origem ao chamado "Relatório Geral" que levou o nome de "Relatório da Comissão Exploradora do Planalto Central do Brasil" também chamado de "Relatório Cruls". As particularidades de clima desértico guiaram algumas diferentes formas de edifícios e de artifícios para impedir a entrada dos intensos raios solares. O concreto era majoritariamente utilizado na vedação dos edifícios, pois consegue barrar grande parte do calor intenso para o interior das edificações, além de ser maleável e conseguir aguentar altas cargas aliado ao aço. $\mathrm{Na}$ época o concreto em frente ao vidro disponível na realidade brasileira era muito mais benéfico para a proteção contra as quebras de temperaturas. Brasília possui um clima onde durante o dia, a radiação solar é de grande intensidade e durante suas noites possui baixas temperaturas e forte ventilação. Por isso, mais uma vez o concerto se mostrou, na época, como uma boa solução para o local (Figuras 1 e 2).

Figuras 1 e 2: Brasília Palace Hotel

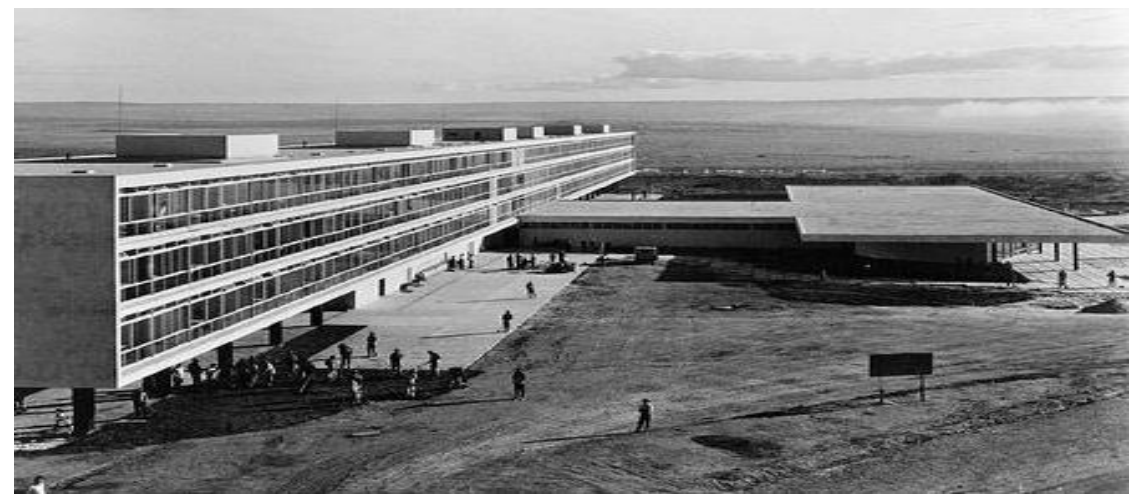




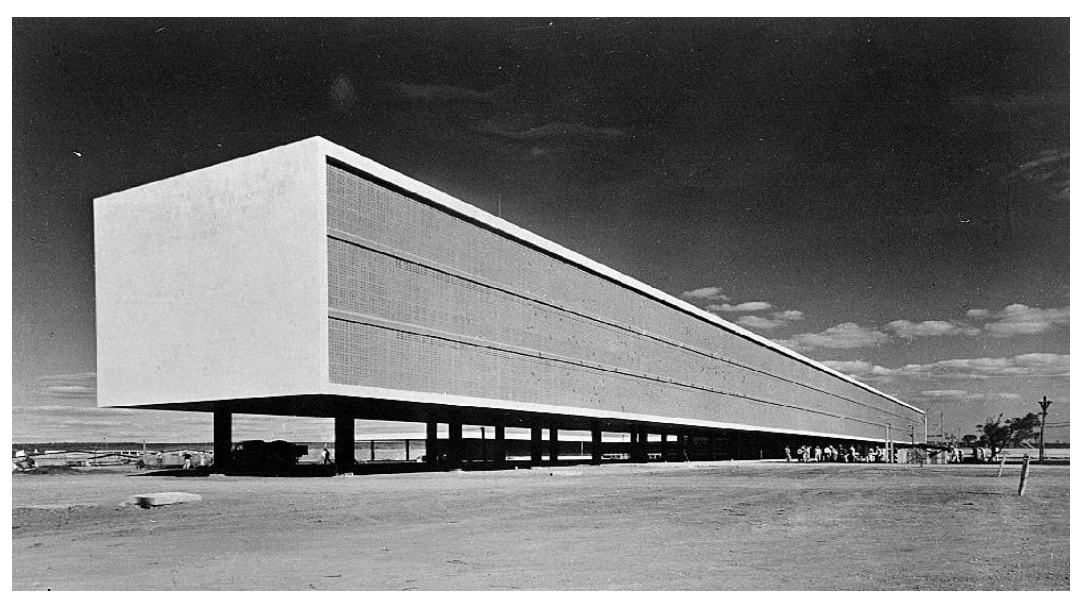

Fonte: www.oscarniemeyer.com.br/obra/pro072, acesso em 25 de junho de 2018.

Segundo Venâncio (2010), para que o projeto sustentável se torne o melhor possível, é importante que a integração da arquitetura com a paisagem se desenvolva na orientação da forma da construção. A orientação das construções é também um recurso utilizado para aumentar o conforto dos moradores e tirar o máximo proveito das soluções sustentáveis adotadas. Para as aberturas de luz natural e ventilação eram usadas as grandes janelas em fita com vidros finos e transparentes. A solução é interessante pelo favorecimento da grande entrada de ventilação, porém o clima de Brasília possui uma intensa radiação solar que se sobressai ao benefício da luz natural. Para a análise dos fatores climáticos é necessário saber-se que os fatores locais dão origens aos microclimas e que os elementos representam os valores relativos a cada tipo de clima. É importante considerar que no clima de um lugar, o dado tem, fundamentalmente, relação com a temperatura e a umidade relativa do ar, velocidade e direção dos ventos e a insolação total horizontal (ROMERO, 2011). O crescimento exponencial de edifícios "caixa de vidro" começou a surgir no hemisfério Norte. Brasília começou usando principalmente vidros translúcidos para compor as fachadas de seus primeiros edifícios. No hemisfério Norte, o vidro transparente exerce uma grande qualidade, pois a entrada de raios solares juntamente com o calor transforma a edificação em uma estufa. Esse efeito mantem o edifício quente no inverno, trazendo conforto ao usuário. Nos climas tropicais, o efeito estufa é totalmente dispensável. Em contrapartida, os atuais edifícios que estão presentes no comércio e serviços possuem diferentes tipos de vidros. A radiação solar absorvida pelo espaço urbano se transforma em calor sensível, comum consequente aumento de temperatura dos próprios materiais, sendo que parte do calor é dissipado para o ar circundante, aumentando a temperatura do ar. A elevada capacidade térmica dos materiais de construção promove o armazenamento de calor que, posteriormente, é emitido por radiação (ROMERO, 2011). A radiação solar 
refletida pelos edifícios sofre ainda fenômenos de múltipla reflexão, sendo que apenas uma pequena parte é refletida para o céu. As edificações armazenam radiação de ondas curtas, aumentando a energia solar absorvidas graças às múltiplas reflexões. É importante ressaltar também que o plantio de árvores é uma solução para a diminuição da temperatura local, visto que suas folhagens absorvem grande parte da radiação solar, tanto direta quanto indiretamente, reduzindo assim, gastos energéticos, como na redução do uso de ar condicionado dentro das edificações (ROMERO, 2011). O sistema fotovoltaico é um sistema formado por células solares que transformam a luz solar em energia elétrica. O sistema é composto pelo módulo, contendo várias células solares conectadas de forma a produzir tensão corrente para a geração de energia, o controlador de carga, que dirige a energia gerada pelo módulo a bateria, protegendo-se de uma sobrecarga, a bateria, que acumula a energia produzida para a posterior liberação e o inversor, que tem a função de transformar a energia corrente contínua, em energia corrente alternada (VENÂNCIO, 2010). Seu funcionamento se dá ao receber os raios do sol, onde os módulos começam a produzir corrente elétrica, em seguida a energia gerada é conduzida por fios ao controlador de carga, do controlador de carga a eletricidade é levada para as baterias, onde é acumulada para o uso diurno e noturno, por fim as baterias enviam a energia acumulada aos inversores, que direcionam a corrente aos aparelhos de tensão diferentes. Os painéis coletores de energia fotovoltaica, além de sua função, podem ser usados como recursos decorativos, cortinas de vidro, brises, fachadas de edifícios ou fechamento de telhado, sendo um bom exemplo de forma e função. As vantagens são diversas, o excedente de energia produzida pode ser vendido a rede pública, a energia é renovável, é silenciosa, é limpa, não emitindo $\mathrm{CO} 2$, é gerada no local, evitando linhas de transmissão e pode ser transportada para outra casa em caso de mudança. Os usos do vidro são de extrema importância pois suas características beneficiam os projetos de diversas maneiras. Porém, é necessário cuidado para aplicação deste nos edifícios. O contentamento tanto dos usuários internos quanto dos externos é imprescindível para o sucesso. Os pedestres não devem ser afetados de maneira negativa enquanto caminham no entorno do edifício. Uma possível solução para a redução de impactos aos usuários é a instalação de painéis fotovoltaicos em fachadas espelhadas e de vidro, que, além de valorizar a tecnologia e a arquitetura, funciona como uma medida benéfica em amplos campos, trazendo não só um método de geração de energia eficiente e limpa, mas também favorecendo o conforto em todos os âmbitos.

Palavras-chave: Arquitetura; Fachada; Vidro; Fotovoltáico; Brasília.

\section{REFERÊNCIAS}

BENÉVOLO, Leonardo. História da Arquitetura Moderna. 
BERGAMO, Ana Paula Rodrigues Horita; MOTTER, Camila Belim. A origem do vidro e seu uso na arquitetura. 2014.

ROMERO, Marta Adriana Bustos. Arquitetura do lugar: uma visão bioclimática da sustentabilidade em Brasília. São Paulo: Nova Técnica, 2011.

VENÂNCIO, Heliomar. Minha casa sustentável: guia para uma construção residencial responsável. 2. ed., Vila Velha, ES: Edição do Autor, 2010. 


\section{HABITAÇÃO SOCIAL PÓS ASSISTÊNCIA TÉCNICA NO DISTRITO FEDERAL}

Ana Luiza Novais de Melo ${ }^{1}$

José Galbinski ${ }^{2}$

\section{RESUMO}

A questão habitacional no Brasil, diante do imponente déficit histórico e persistente em nossos dias, assume enorme impacto na sociedade, o que revela a relevância social do tema habitação. Os problemas urbanos daí decorrentes agravam o quadro social no Distrito Federal com reflexos não só na questão da moradia, mas igualmente, na saúde, na educação, nos transportes, no emprego e na questão fundiária. A jovem capital do país enfrenta sérios problemas habitacionais, devido à situação fundiária relativamente frágil e ao elevado custo da terra. Estima-se que aproximadamente $25 \%$ dos habitantes do DF vivam em um empreendimento irregular, segundo a Companhia de Desenvolvimento Habitacional do DF (Codhab). Até mesmo a população de média renda tem dificuldade de acessar aos imóveis regulares, devido ao seu alto custo. Mais de $85 \%$ dos brasileiros constroem e reformam, sem orientação de arquitetos e urbanistas ou engenheiros. Esse número foi levantado a partir da pesquisa realizada pelo CAU/BR e pelo Instituto DataFolha, em 2015. No Brasil, grande parte da população de baixa renda "resolve" seu problema da moradia pela autoconstrução improvisada e sem orientação técnica de um profissional, essa realidade é comum em diversas cidades do país, como visto nas favelas das médias e grandes cidades e sobretudo nas metrópoles. Uma edificação para moradia, independente do seu valor, deve satisfazer a uma série de requisitos de desempenho para a ocupação, objetivando a satisfação dos usuários quanto às suas condições. A avaliação de desempenho é uma abordagem complexa, em que interagem diversos fatores, consiste em avaliar o comportamento da habitação, quanto seus elementos de instalações prediais, desempenho espacial (funcionalidade), desempenho térmico, visual (luminoso), acústico, desempenho quanto à qualidade do ar e quanto à integridade da edificação (estrutural, proteção quanto às intempéries). Uma pequena parte da população tem conhecimento da existência da Lei de Assistência Técnica No 11.888, de 24 de dezembro de 2008, que

\footnotetext{
${ }^{1}$ Centro Universitário de Brasília / ananovais.arq@gmail.com

${ }^{2}$ Centro Universitário de Brasília / jose.galbinski@ceub.edu.br
} 
assegura o direito das famílias de baixa renda à assistência técnica pública e gratuita para o projeto e a construção de habitação de interesse social. A pesquisa tem como finalidade avaliar a melhora no desempenho da habitação e do grau de satisfação do morador - antes e depois - das intervenções de assistência técnica, através de estudos de casos, analisando as unidades individuais dos conjuntos habitacionais de interesse social e método experimental onde os problemas de conforto ambiental, estrutura e funcionalidade das habitações são analisados. O agravamento da falta de moradia e o excesso de moradias precárias ou insalubres nas cidades brasileiras e principalmente no Distrito Federal e entorno se transformou em uma questão social ao longo dos anos, transcende as questões econômicas, atingindo problemas políticos, sociais e espaciais. Considerando as questões econômicas de uma habitação e da assistência técnica o aumento de área $\left(\mathrm{m}^{2}\right)$ reflete no custo da construção. No entanto, esse custo pode ser minimizado por meio do tratamento de outros elementos que reduzem o custo, como por exemplo, a geometria do espaço, o sistema construtivo ou seus componentes; sendo considerados importantes aspectos a serem avaliados. $\mathrm{O}$ projeto de habitação de promoção pública deve ter como objetivo a melhoria da qualidade de vida da população, promovendo a ideia de pertencimento dos moradores com o "lugar", gerando satisfação e tendo por consequência a fixação à moradia e o bom retorno do investimento público para as famílias e para a cidade. A arquitetura e urbanismo cumprem suas funções de promover bons espaços para pessoas. Esses aspectos devem ser definidos durante a fase de assistência técnica no planejamento, quando o projeto é concebido, pois interpretam os critérios para definição da dimensão física da moradia. Teoricamente, o projeto de habitação deve ser específico para cada indivíduo e família, respeitando sua rotina, hábitos, cultura, modo de vida, orçamento, necessidades e desejos distintos. Quando essa habitação é dita de "interesse social", ou seja, proposta dentro de políticas e programas públicos voltados à população de menor renda e subsidiada com verba pública federal, estadual ou municipal, esses aspectos tomam outro sentido, sendo o fator econômico o que prevalece. No Brasil, a produção da habitação de interesse social tem como objetivo principal a quantidade de oferta em razão da qualidade do projeto. Muitos dos aspectos relacionados ao usuário são postos de lado em prol de um objetivo aparentemente superior, sua maior padronização para uma maior economia que resulte em maior número de unidades produzidas e consequentemente uma maior satisfação dos usuários. Essa tem sido a premissa dos programas de produção habitacional públicos brasileiros nos últimos 50 anos (PEREIRA, 2015). O contexto da desorganização espacial nas cidades do país é produto, dentre outros aspectos, de uma dificuldade de acesso à terra legalizada pela população pobre, pela condição de informalidade na economia, pelo desemprego e pela postura negligente do Estado em relação aos danos causados pelo setor privado, restando aos mais carentes ocuparem áreas sensíveis no aspecto ambiental agravando a já precária forma de morar e aumentando a segregação espacial tanto intra-urbana quanto periférica 
(CAU/PB). A pesquisa busca elaborar um método de avaliação do desempenho das habitações, gerando requisitos mínimos e concepções para um bom desenvolvimento de projeto de arquitetura e de assistência técnica para habitação de interesse social. Gerando contribuições de concepções básicas para o melhor aproveitamento da sustentabilidade no conforto ambiental, gerando soluções economicamente viáveis de serem adotas nos projetos de assistência técnica para população de baixa renda.

Palavras-chave: Avaliação pós-ocupação; Assistência Técnica; Melhoria Habitacional; Déficit Habitacional; Habitação social.

\section{REFERÊNCIAS}

ABIKO, Alex Kenya; ORNSTEIN, Sheila Walbe. Inserção urbana e avaliação Pósocupação (APO) da habitação de interesse social. São Paulo: FAU/USP, 2002 (Coletânea Habitare/FINEP, 1).

BONDUKI, Nabil. Os Pioneiros da habitação social. São Paulo: Unesp, 2014. v. 1

CANUTO, Elza Maria Alvez. Direito à moradia urbana: aspectos da dignidade da pessoa humana. Belo Horizonte: Fórum 2010.

FERNANDES, Edésio; ALFONSIN, Betânia (Coord.). Direito à moradia adequada: o que é, para quem serve, como defender e efetivar. Belo Horizonte: Fórum, 2014.

LEITE, B. C. C. Avaliação de desempenho de edificações de escritórios sob o ponto de vista do conforto térmico. São Paulo: FAU/USP, 1997.

LIPIETZ, Alain. Alguns problemas da produção monopolista do espaço urbano, Espaço e Debates, São Paulo, n. 7, 1982.

\section{PEREIRA, Gabriela Morais. Funcionalidade e qualidade dimensional na}

habitação: contribuição à NBR 15.575/2013. Tese (Doutorado) - Programa de PósGraduação em Arquitetura e Urbanismo, Universidade Federal de Santa Catarina, Florianópolis, 2015. 
INVISIBILIDADE URBANA:

\title{
A RELAÇÃO ENTRE MORADORES DE RUA E A CIDADE
}

\author{
Paulo Fernando Lisbôa de Vasconcelos ${ }^{1}$
}

Paulo Afonso Cavichioli Carmona ${ }^{2}$

\section{RESUMO}

Este documento refere-se à uma visão geral a respeito de fatores determinantes para o surgimento da pobreza e desigualdades sociais nos centros urbanos da era moderna e de que forma se deram as políticas de cunho socioeconômicas para se controlar a expansão deste fenômeno ao longo do tempo. Nas antigas civilizações com o surgimento dos centros urbanos, era comum a presença de pessoas itinerantes habitando as ruas das cidades. Sem emprego ou moradia fixa, estes geralmente eram vítimas de desapropriações forçadas, guerras, e outras calamidades, e sem muitas alternativas, passam a serem obrigados a buscar sua sobrevivência a partir da caridade alheia. Estas pessoas moradoras de rua passaram a ser vistos com um problema à medida que os centros urbanos se desenvolviam, o que estimulou a criação de "Leis Antivadiagem", que previam a restrição de acesso à determinadas áreas das cidades como também o de forçar os trabalhadores a aceitarem subempregos com baixos salários. Com o passar dos séculos, os motivos para o aumento da população de rua pouco mudaram, apenas se "modernizaram" paralelamente com o desenvolvimento da sociedade. Ao se observar a atual situação do Brasil, segundo o Ipea no ano de 2015, estimou-se que existam 101.854 brasileiros em situação de rua, porem a realidade pode ser ainda pior, pois segundo dados do Ministério do Desenvolvimento Social, até 2015, das 5.570 cidades brasileiras, 4.309 secretarias municipais declararam não ter levantamentos ou dados sobre essa população, o que reforça a sensação do quão invisíveis são os problemas desta parcela da população em meio ao contexto social como um todo. O objetivo deste artigo é trazer uma visão geral, por amostragem, da situação em que se encontra a população em situação de rua nos principais centros urbanos brasileiros, e de que forma este tema tem sido tratado pela sociedade e pelo Poder Público. Uma das grandes dificuldades para a implementação de Políticas

\footnotetext{
${ }^{1}$ Centro Universitário de Brasília / pauloflvasc@gmail.com

${ }^{2}$ Centro Universitário de Brasília / paulo.carmona@ceub.edu.br
} 
Públicas no Brasil voltadas para a população em situação de rua é inicialmente de se entender a dimensão do problema. Tal dificuldade pode ser compreendida ao se observar o comportamento nômade dos desprovidos de moradia convencional, o que dificulta uma verificação precisa e definitiva por parte dos agentes públicos de sua real situação em grande parte do território nacional. A partir de dados obtidos de documentos oficiais disponibilizados pelo IPEA e FIPE - São Paulo, produzidos através do Censo realizado no ano de 2015, foram selecionados índices para que fosse feita uma análise da diversidade de perfis dos moradores em situação de rua no Brasil. Os índices escolhidos foram a divisão por gênero, idade, nível de instrução, divisão por atividade que exercem e por doenças relatadas. Seguiu-se então um estudo baseado em relatos documentados dos próprios moradores de rua e instituições públicas sobre os fatores que poderiam justificar os dados apresentados pelo levantamento do Censo. Os resultados obtidos com os dados oficiais e posteriormente com o estudo aprofundado de cada um deles, foram de grande valia para se tentar entender em parte os variados perfis que compõem essa parcela da população que muitas vezes passa despercebida em nossos centros urbanos, expondo a sua difícil e complexa realidade. Pois como foi constado, diversos são os fatores que levaram as pessoas às ruas, como também são diversos os fatores que as impede de sair delas, o que nos faz levantar questionamentos se nossas políticas públicas, como também a configuração urbana de nossas cidades, são capazes de atender esta população em seu estado de vulnerabilidade e, se possível, também reverter esta realidade. Como foi possível observar neste trabalho, muitos foram os avanços conquistados pela parcela da população mais desfavorecida ao longo do tempo, porém ainda assim é difícil de conceber a ideia de que se levou tanto tempo para se constatar o obvio, que as garantias dos direitos e necessidades básica desempenham um importante papel para a diminuição das desigualdades e da miséria nos centros urbanos, proporcionando melhores condições para que os indivíduos continuem a sua busca por melhores condições de vida para si mesmos e suas famílias. Mas para isso, mostra-se indispensável o comprometimento de se estudar o perfil físico e psicológico de cada grupo, evitando-se generalizações, para que a partir de suas peculiaridades, se desenvolvam programas mais direcionados e se obtenham resultados mais satisfatórios e de forma mais eficiente, economizando assim recursos públicos e principalmente tempo, que muitas vezes esta parcela da sociedade não tem.

Palavras-chave: Desigualdades; Moradores de rua; Estado.

\section{REFERÊNCIAS}

FRANGELLA, S. M. Corpos urbanos errantes: uma etnografia da corporalidade de moradores de rua em São Paulo. Campinas, 2004. 
NATALINO, M. A. C. Estimativa da população em situação de rua no Brasil. Brasília: IPEA: 2016

PESQUISA censitária da população em situação de rua, caracterização socioeconômica da população adulta em situação de rua e relatório temático de identificação das necessidades desta população na cidade de São Paulo. São Paulo: FIPE: 2015 


\title{
OS DESAFIOS DA MOBILIDADE A PÉ NOS COMÉRCIOS LOCAIS DO PLANO PILOTO DE BRASÍLIA
}

\author{
Natália Costa Araujo ${ }^{1}$ \\ Eveline dos Santos Guimarães ${ }^{2}$ \\ Ana Paula Borba Gonçalves Barros ${ }^{3}$
}

\section{RESUMO}

$\mathrm{O}$ ato de caminhar faz parte da humanidade desde sua existência e para a mobilidade urbana o pedestre é o ponto crucial. Segundo Barros (2014) "com o advento do automóvel pós Revolução Industrial, os deslocamentos a pé têm sofrido um processo de mitificação em prol da comodidade motorizada.” Em Brasilia, o carro é privilegiado e o ato de caminhar não tem vez. Geralmente quando um turista ou um novo morador chega à cidade ele percebe logo a quão difícil é ver o movimento de pedestres na nas ruas, até mesmo em áreas comerciais. Um dos motivos para essa ausência de indivíduos transitando pelas ruas é justificado pelo estilo modernista implantado. O modo como os prédios, acesso e trajetos para pedestres foram situados, são totalmente desfavoráveis aos usuários. O Modernismo visava uma cidade cheia de prédios, com monumentos, espaços vazios, e grandes vias para um grande fluxo de veiculos. Andar a pé em Brasília é cansativo, com longas distâncias a se percorrer, sem atrativos e sem pessoas nas ruas. Neste contexto, Brasília, caracterizada como Forma Modernista (CARVALHO, 2003), apresenta-se como uma configuração que desestimula o uso dos espaços, o que vai de encontro aos preceitos de (JACOBS,2000) e (GEHL,2010), quando dizem sobre a importância dos usos variados, que trazem as pessoas para as ruas. Alguns autores (Holanda, 2002; Medeiros, 2013; Barros, 2014) apontam como a Forma Urbana atua sobre o ato de caminhar, sendo capaz de alterar a mobilidade da cidade. Com base no exposto acima, este trabalho tem como objetivo apresentar as diferenças morfológicas existentes nos comércios locais do Plano Piloto de Brasília, comparando

\footnotetext{
${ }^{1}$ Centro Universitário de Brasília / natalia.a.arquiteta@gmail.com

${ }^{2}$ Centro Universitário de Brasília / ineguimaraes@hotmail.com

${ }^{3}$ Centro Universitário de Brasília e Universidade de Lisboa / ana.barros@ceub.edu.br
} 
especificamente a Asa Sul e Asa Norte. Para tanto, como procedimentos metodológicos, realizaram-se alguns levantamentos, tais como: (a) uso do solo, (b) número de portas e (c) de contagens de pedestres com o Método dos Portais - onde se cria uma linha imaginária cruzando um determinado trajeto, e durante um período de 2,5 minutos quando um pedestre atravessa esta linha imaginária ele é incluído na contagem. Todas as contagens foram realizadas entre as $17 \mathrm{~h}$ e $19 \mathrm{~h}$, em dias de terça-feira, quarta-feira e quinta-feira, em semanas sem feridos para não alterar o resultado da pesquisa. Foram escolhidas oito comerciais locais quatro na Asa Sul, CLS 201/202, CLS 109/110, CLS 412/413 e CLS 314/315 e quatro na Asa Norte, CLN 103/104, CLN 205/206, CLN 308/309 e CLN 413/414. Verificou-se que a configuração do comércio da Asa Sul, difere, em certa medida, do comércio da Asa Norte, fomentando diferentes padrões de deslocamentos a pé. O resultado obtido foi que a Asa Norte possui mais tráfego de pedestres, mostrando a importância do número de portas, que segundo (GEHL,2010) interfere nitidamente na quantidade de pessoas na rua. A quadra com mais movimento de pedestres foi a 308/309 norte, e é a quadra que possui mais diversidade nas funções das lojas. Ela mistura restaurante e bares, com lojas de vestuários e cria uma grande movimentação que atrai pessoas, e faz com que se torne uma quadra mais segura, afirmando o que diz (JACOBS,2000) sobre a importância da diversidade dos usos. Por possuir restaurante e bares espalhados nos blocos, no período da noite essa quadra também possui movimento em toda sua extensão, criando um lugar atrativo para visitar, pois quanto mais olhos se têm em um lugar público mais seguro fica. A quadra CLS 201/202, foi a que teve o segundo maior fluxo de pessoas em nossa análise, mas vale ressaltar que o fator determinante para ter esse grande número de pessoas não foi só a sua variedade de funções, mas também a sua localização. Essa comercial está situada entre uma quadra residencial (SQS 202) e o Setor Bancário sul, que é uma área de grandes prédios corporativos, com um grande número de pessoas. $O$ grande fluxo de pedestres dessa quadra vem das pessoas que frequentam o Setor bancário sul, que na maioria das vezes se deslocam até a comercial para usufruir da grande quantidade de comércios do gênero alimentício. A curta distância para um objetivo comum, se alimentar, estimula os usuários do Setor Bancário Sul a frequentarem a comercial CLS 201/202, contribuindo então para que a quadra seja um local movimentado. Umas das quadras com menor fluxo de pedestres foi a CLN 412/413. O baixo número de pedestres nessa quadra é justificado pelo grande número de restaurantes e bares que tem como principal foco a atividade noturna, fazendo com que não haja muitos motivos para visitar a quadra durante outros períodos do dia. Outro motivo para ter tão pouco movimento, é a densidade populacional. Atrás do comercio local da CLN 413 existe um parque, dessa forma não possui quadra residencial o que faz com que essas comerciais não tenham pessoas suficientes para movimentar o comercio. Segundo (JACOBS, 2000) a densidade alta é importante para uma cidade viva, observando que densidade é diferente de superlotação. Outra quadra que 
chamou atenção para o baixo fluxo foi a CLS 110/109 conhecida como a "quadra das elétricas". Está comercial tem a menor diversidade de funções entre todas as oito quadras estudadas. Entre todas as lojas observadas apenas $21 \%$ delas não estão relacionadas à iluminação e elétrica. Essa setorização também acontece em algumas outras quadras do Plano Piloto. Em uma cidade é necessária diversidade de funções, para que se torne mais segura, com movimento em horários distintos. Esta comercial sofre com poucas variações de experiências e não reforça a vida na cidade. As pessoas que a frequentam vão na maioria das vezes, procurar seus itens relacionados à elétrica e vão embora, ela não permite que o usuário possa experimentar uma parada espontânea, a imprevisibilidade e os contatos passivos de ver e ouvir. Quando encontramos uma variação de uso nessa comercial, eles estão localizados em dois grandes blocos distintos que contém também apenas uma função, exercendo praticamente uma única atividade o dia todo. Dessa forma infere-se que a forma urbana tende a interferir nos deslocamentos a pé, tendo o Modernismo prejudicado a mobilidade. Uma cidade saudável é uma cidade caminhável.

Palavras-chave: Mobilidade; Caminhabilidade; Forma Urbana; Pedestre; Brasília.

\section{REFERÊNCIAS}

BARROS, Ana Paula. Diz-me como andas que te direis onde estas. Tese

(Doutorado em regime de co-tutela). Brasília: Universidade de Brasilia; Lisboa:

Universidade de Lisboa, 2014.

CARVALHO, J. Formas Urbanas. Coimbra: Minerva Coimbra, 2003.

GEHL, J. Cities for people. Washington: Island Press, 2010.

HOLANDA, F. O espaço de exceção. Brasilia: EdUnb, 2002.

JACOBS, J. Vida e morte de grandes cidades. Sao Paulo: M. Fontes, 2000.

MEDEIROS, V. Urbis Brasiliae. Brasilia: EdUnb, 2013. 


\section{PAVIMENTO PERMEÁVEL COMO SOLUÇÃO PARA ESCOAMENTO SUPERFICIAL EM ÁREAS URBANAS: ESTUDO DE CASO EM ESTACIONAMENTO NO PLANO PILOTO DE BRASÍLIA/DF}

Luana Moreira $^{1}$

Neusa Maria Bezerra Mota²

\section{RESUMO}

Alguns desastres naturais como alterações climáticas, enchentes e alagamentos são consequências e reflexos da grande urbanização e ocupação desenfreada das cidades. Em virtude dessa intensa ocupação, as áreas de infiltração ou áreas permeáveis em centros urbanos estão diminuindo gradualmente e o solo está ficando cada vez mais impermeável. Uma das soluções empregadas pelos órgãos públicos para solucionar este problema está na instalação de sistemas de drenagem, usualmente com a execução sarjetas nos lados adjacentes das rodovias, que têm a função de conduzir a água para áreas permeáveis. Contudo, esta prática muitas vezes apenas faz com que a enchente se direcione para outro lugar, mudando apenas a localização do problema. Nos dias atuais, para evitar mais desastres causados pelo escoamento superficial das águas pluviais, é indispensável a busca por alternativas que sejam sustentáveis e que otimizem o espaço urbano das cidades. Assim sendo, a presente pesquisa sugere a construção de pavimentos permeáveis como meio para reduzir ou até mesmo solucionar os problemas causados por escoamento superficial da água da chuva em edificações, além de trazer um estudo de caso sobre a análise da capacidade de infiltração de um solo para a execução deste tipo de pavimento. $\mathrm{O}$ pavimento permeável consiste em atender às solicitações de esforços mecânicos de carga de rolamento de veículos e pedestres, e ao mesmo tempo e permite a infiltração da água no solo, evitando o escoamento superficial, sem causar dano à sua estrutura. Este tipo de pavimento é ideal para ser executado em estacionamentos e calçadas, onde geralmente a carga gerada pela circulação de veículos e pessoas não é elevada. Quando não há um bom planejamento de drenagem, seja em edificações comuns como casas e prédios ou em obras de pavimentação, a água escoada é direcionada

\footnotetext{
${ }^{1}$ Centro Universitário de Brasília / luanamoreira9@hotmail.com

${ }^{2}$ Centro Universitário de Brasília / neusamota@ceub.edu.br
} 
para bacias adjacentes àquela região da edificação. De acordo com Sudersha (2002), os projetos de drenagem urbana têm como filosofia o escoamento da água precipitada o mais rápido possível para fora da área em que ela se projeta. Este critério aumenta as vazões máximas, a frequência e o nível de inundação de áreas a jusante. Para Vaz (2004), a drenagem urbana é composta de medidas que tenham como propósito reduzir os prejuízos causados por inundações, proporcionando o desenvolvimento urbano de forma harmônica, articulada e sustentável. Quer dizer, a drenagem é o gerenciamento da água da chuva que escoa no espaço urbano. De acordo com Oliveira (2017), para amenizar o problema é necessário investir em materiais e métodos que se apliquem na área montante, impedindo que a precipitação chegue ao sistema de drenagem com a velocidade, o volume e poluentes aumentados. Ao passo que a urbanização das cidades cresce, as áreas de infiltração de água no solo estão se extinguindo. De acordo com o Guia de Dimensionamento da Interpave (2010), em uma região de zona rural com cobertura florestal, 95\% das águas pluviais se infiltra no solo, enquanto nos centros urbanos esta taxa diminui para 5\%. Uma das alternativas para reduzir o impacto gerado pela impermeabilização do solo está na construção de pavimentos permeáveis. Este tipo de pavimento possibilita o direcionamento da água da chuva para o solo de acordo com sua capacidade de permeabilidade. Outro ponto favorável está na possibilidade de proporcionar ao pavimento não apenas a função de suportar as cargas de veículos e pedestres, mas também contribuir para a infiltração de água no solo. Segundo a NBR 16.416 (ABNT, 2015), sobre pavimentos permeáveis de concreto, o pavimento permeável é um pavimento que atende simultaneamente às solicitações de esforços mecânicos e condições de rolamento, cuja estrutura permite a percolação e/ou o acúmulo temporário de água, diminuindo o escoamento superficial, sem causar dano à sua estrutura. De acordo com Marchioni e Silva (2011), os pavimentos permeáveis são definidos como aqueles que possuem espaços livres na sua estrutura onde a água pode atravessar. O objetivo é minimizar os impactos da urbanização atuando na quantidade e qualidade do escoamento superficial de forma sustentável. A seção típica de um pavimento permeável é composta pelas seguintes camadas: revestimento com placa de concreto permeável de cimento Portland ou asfalto, sobre uma camada de material de assentamento (areia); base granular composta por brita; sub-base com material um pouco menos resistente que a camada de base (quando necessária); sub-leito (solo natural do local) que à rigor não faz parte da estrutura do pavimento, e, quando necessário, tubulação de drenagem para escoamento do excesso de água. Sobre o dimensionamento do pavimento permeável, WAPA (2015), diz que ao contrário dos pavimentos convencionais, os pavimentos permeáveis são tipicamente construídos sobre um sub-leito não compactado, maximizando assim a infiltração da água no solo. Para iniciar o dimensionamento do pavimento permeável é necessário que primeiro sejam feitos estudos hidrológicos das bacias de contribuição e dos índices pluviométricos da região onde o pavimento será 
executado, para estimar a quantidade de água que aquele local irá receber. É importante ressaltar que o solo precisa de um determinado tempo para que consiga absorver toda a água que está em sua superfície. Este tempo é determinado de acordo com as características de infiltração e capacidade de permeabilidade do sub-leito. Assim sendo, as espessuras das camadas do pavimento permeável são dimensionadas, não apenas baseada na solicitação de carga do pavimento, mas também de acordo com a quantidade de água que terá que armazenar para não haver escoamento superficial no local. Nesta pesquisa foi realizado um estudo de caso para avaliar a capacidade de permeabilidade do subleito de um estacionamento que terá sua concepção alterada para ser de pavimento permeável. O referido estacionamento situa-se no campus do Centro Universitário de Brasília (UniCEUB), na Asa Norte, no Plano Piloto de Brasília/DF. A metodologia empregada para definir o coeficiente de infiltração do pavimento foi baseada nos ensaios dos Cilindros Concêntricos e Permeabilidade pelo Método de Porchet descritos em MINVU (1996). O ensaio de Infiltração Duplo Anel tem a intenção de medir a infiltração vertical da água no solo. O método consiste em cravar no solo dois infiltrômetros cilíndricos (um com diâmetro de $25 \mathrm{~cm}$ e outro de $50 \mathrm{~cm}$ ) em uma profundidade de $10 \mathrm{~cm}$. Em seguida, coloca-se água em ambos os cilindros, mantendo o mesmo nível de água entre eles. Durante o ensaio mede-se a quantidade de água infiltrada e o tempo que a água leva para infiltrar no solo. Uma vez que as condições de regime entre o tempo e a taxa de infiltração o ensaio é encerrado. Para realizar o ensaio de Permeabilidade de Porchet é escavado um cilindro no solo para que a permeabilidade global seja medida. $\mathrm{O}$ procedimento deste ensaio consiste em escavar um poço onde as dimensões sejam compatíveis com a profundidade da obra/pavimento, e em seguida adiciona-se água de forma que preencha toda a área do cilindro. Mede-se respectivamente o tempo e a quantidade de água que está sendo infiltrada no solo. No estacionamento em estudo ambos os ensaios citados foram feitos em quatro áreas do local. Para a realização do ensaio de infiltração primeiramente foi escavado um cilindro de $80 \mathrm{~cm}$ de diâmetro com $40 \mathrm{~cm}$ de profundidade para que os infiltrômetros fossem cravados na superfície real do subleito. Após a realização do ensaio de infiltração, foi escavado um cilindro de $30 \mathrm{~cm}$ de diâmetro com $70 \mathrm{~cm}$ de profundidade para a execução o ensaio de Porchet. Após a realização dos ensaios, os dados anotados foram tratados e analisados em planilhas Excel. Foi obtida a taxa de permeabilidade do solo do estacionamento estudado de $4,9 \times 10^{-5} \mathrm{~m} / \mathrm{s}$. Esta taxa foi calculada com base na média dos resultados obtidos nas quatro áreas de realização do ensaio. Comparando este resultado com especificações da NBR 16.416 (ABNT, 2015), é possível identificar que o subleito do estacionamento em estudo tem capacidade parcial de infiltração, o que implica que para o estacionamento ter um bom desempenho quanto à infiltração, será necessário a instalação de tubos drenantes sobre o subleito para escoar o excesso de água. Neste caso, pode-se concluir que a existência de área de infiltração em edificações é fundamental para que não haja escoamento superficial de água na 
região. Conforme evidenciado na pesquisa, o desenvolvimento urbano das cidades está fazendo com que o solo fique cada dia mais impermeável, provocando assim o escoamento superficial de águas pluviais e promovendo alguns possíveis desastres, decorrentes de enchentes. Entende-se que esta situação pode ser amenizada ou até mesmo evitada com a instalação de pavimentos permeáveis, e neste contexto, a implementação de estacionamentos compostos por pavimento permeável é uma possível solução para evitar escoamentos superficiais e enchentes em grandes centros urbanos.

Palavras-chave: Pavimento Permeável; Escoamento Superficial; Infiltração.

\section{REFERÊNCIAS}

ASSOCIAÇÃO BRASILEIRA DE NORMAS TÉCNICAS. NBR 16.416: Pavimentos permeáveis de concreto - requisitos e procedimentos. Rio de Janeiro: ABNT, 2015.

CHILE. Ministerio de Vivienda y Urbanismo. Técnicas alternativas para soluciones de aguas lluviais em sectores urbanos: guía de diseño. Santiago, 1996.

\section{OLIVEIRA, L. C. B. Análise da permeabilidade e da colmatação em concretos} permeáveis produzidos com agregado reciclado de concreto. $2017.106 \mathrm{f}$. Dissertação (Mestrado) - Pontificia Universidade Católica de Campinas, Campinas, 2017.

SUPERINTENDÊNCIA DE DESENVOLVIMENTO DE RECURSOS HÍDRICOS E SANEAMENTO AMBIENTAL. Manual de drenagem urbana: região metropolitana de Curitiba. Curitiba, 2002.

THE PRECASTE CONCRETE PAVING ASSOCIATION. Permeable pavements: Guide to design, construction and maintenance of concrete block permeable pavements. 6. ed., Leicester, 2010. (Publicação L534:L217).

VAZ, B. V. Drenagem urbana. Boletim Informativo, Santa Cruz do Sul, ano 6, n. 5, 2004.

WISCONSIN ASPHALT PAVEMENT ASSOCIATION. Technical Bulletin: Porous Asphalt Pavements. Wisconsin, 2015. 


\section{PODER E CINEMA NO ENSINO DE ARQUITETURA}

Ricardo Cesar Machado ${ }^{1}$

\section{RESUMO}

Este artigo aborda o poder não prepotente como instrumento a serviço da mudança, a grande influência que o professor exerce nos seus alunos, seja positiva ou negativa, e reforça a ideia de que a maioria dos estudantes se espelha nos seus mestres. $O$ texto também relaciona dois fatos acadêmicos da vida de um professor de Arquitetura e Engenharia do Centro Universitário de Brasília. Primeiro ato, ocorrido em julho de 2012, durante o doutorado em humanidades e artes com menção em ciências da educação, na Argentina, Universidade Nacional de Rosário. Especificamente do seminário de pós-graduação Política e Poder Educação realizado pelo autor. Segundo ato, em janeiro de 2008, é análise de prática inusitada de ensino de arquitetura no UniCEUB, também vivenciada pelo autor. $\mathrm{O}$ assunto abarca a realização do filme educativo chamado Porcus Píritus, especificamente, o planejamento deste produto audiovisual. Ausência de demonstração do poder do audiovisual no ensino de arquitetura. Consolidar o sentido de poder não prepotente do professor na educação universitária. Analisar a experiência teórico/prática da préprodução do filme de curta metragem Porcus Píritus. Relacionar poder, educação e audiovisual junto aos alunos de arquitetura do UniCEUB. Interpretações livres e anotações do seminário de pós-graduação Educação, Política e Poder. Pesquisa bibliográfica e investigação on line acerca dos autores citados naquele seminário. Estudo de caso do filme Porcus Píritus. Consideração dos elementos de produção e pós-produção do curta metragem. Análise da distribuição do filme e pesquisa de reação do espectador/aluno (nove anos de observação). Possivelmente todos os diplomas, se não estão a serviço da transformação do saber, para melhora-lo, para que servem? Quiçá o saber constitua-se num instrumento a serviço do poder, educação e emancipação! Este poder se compõe (ou não) com os discursos educativos das palavras na relação professor/aluno. A universidade é exercício das práticas do capital cultural (e econômico) das classes dominantes. É preciso, primeiro, a nossa transformação, depois, a transformação das outras pessoas. No ensino de projeto de arquitetura ocorre a didática do erro, onde a ideia nasce

\footnotetext{
${ }^{1}$ Centro Universitário de Brasília / ricardo.machado@ceub.edu.br
} 
incipiente e vai amadurecendo, evoluindo: Errar na escola, acertar na profissão! Dor e o sofrimento não são, necessariamente, pré-requisitos para a aquisição de conhecimento! Portanto, os professores devem se reciclar, renovar e ampliar o pensamento a cada ano para evitar a brutalidade imposta à conduta acomodada na monotonia. Viver harmoniosamente é importante, porém, o educador de arquitetura deve ter extrema atenção para não ficar nos balcões, na segurança das galerias, e quiçá, cuidar-se dos perigos da acomodação, mas, é muito fácil fechar os olhos. $\mathrm{O}$ caso é qualitativo, pequenas palavras dos professores que criam grande impacto sobre os estudantes de arquitetura. $\mathrm{O}$ analisador institucional é como a metáfora da ponta do iceberg, deve ser revelada a porção oculta ao aluno (que é muito maior). Portanto, decerto a escola de arquitetura também pode compartilhar desse olhar como empresa do projeto, com sua estrutura organizacional, integrada, psicossocial e contextual às condições de trabalho e sistema político. Os docentes de arquitetura e o toque psicológico para reconhecer as condições dos alunos, porém, sem abrir mão da sua composição vertical inerente de todo maestro. Professor explicador é essencial, ele pode ensinar até o que não sabe! Cria uma instância inspiradora e não atordoa os alunos. Os estudantes não são uma "folha" em branco ou um copo vazio, eles têm algo a compartilhar. Professores transmissores de arquitetura, mas sua transmissão pode ser interrompida para dar lugar às diferenças. Possivelmente, a novidade não deva ser mera reprodução do que já foi dito pelos tempos, ou seja, decerto deve se apresentar um pensamento renovado. Talvez reconstrução com novo discernimento, se valer do efeito político do poder do professor para distribuir as "verdades acadêmicas": a genealógica, com distribuição de discursos históricos e, também, a arqueológica, com explicações e aprofundamento do discurso histórico. Quem sabe seja preciso a institucionalização da ternura! Segmento pedagógico versus a perseguição pedagógica ocorre porque existe a ausência de um terceiro segmento: dar-se conta de si. Possivelmente, bom tratamento seja fundamental para o sujeito ético e pode (ou não) estar presente na sala de aula. Então, a formação dos estudantes de arquitetura poderá ser simbólica, técnica e espiritual. Pode ser necessário "elevar âncoras" para mirar outros horizontes, por que talvez as raízes corram o risco de apodrecerem: "Os meus alunos, minha sala de aula! Mas... Nunca foram seus"! Aqui se entenda esta expressão anterior como ausência de prepotência, trata-se de consciência acadêmica docente. A segunda parte do artigo em questão consistiu na análise da preparação de filme Porcus Píritus chamada de "préprodução", foi um filme encomendado pelos veteranos da arquitetura ao coordenador do curso. A seguir, o briefing da situação que causou o evento: "Eles estavam poucos sensíveis frente ao caos, sujeira e desordem depois das aulas que os calouros deixavam os laboratórios e ateliês de projeto. $\mathrm{Na}$ época os veteranos reivindicaram, pelos seus poderes adquiridos, um posicionamento educativo da instituição de ensino aos ingressantes, e ainda, um posicionamento corretivo! O mais interessante é que a forma educacional foi bem definida, não qualquer correção: 
somente por meio de uma mensagem audiovisual!" Porcus Píritus foi concebido para ter, pretensiosamente, aquele poder de educação requerido pelos veteranos. Pretendia-se implantar na cabeça do calouro de arquitetura do UniCEUB a harmonia e preservação dos lugares de trabalho acadêmico. Algo que se julga saldável e educativo! Os estudantes de arquitetura aprendem a organizar espaços para os seus clientes, portanto, seus ambientes de trabalho (e estudos também) devem ser organizados para gerar credibilidade. Caso o aluno não possa organizar o próprio espaço, como organizará espaços para terceiros? Foi realizada uma extensa pesquisa com os "clientes". Durante esta investigação verificou-se a existência do maior número de mulheres em relação aos de homens. Identificou-se, então, que talvez a inclusão de uma protagonista feminina no filme pretendido poderia ser bastante eficaz para gerar empatia no público-alvo. Depois de outras pesquisas, levantaram-se as reais situações críticas. Fatos que, posteriormente, permaneceram na película como "referências da realidade". Estes relatos mantiveram-se no filme não de maneira "literal", mas "traduzidos" e organizados de maneira considerada "emocionante", ou seja, em concordância comovente. De acordo com um gênero de filme chamado "docudrama". Desde o início intentou-se um enfoque persuasivo na obra audiovisual, com o claro objetivo de conceber um produto fílmico "viral", que gerasse curiosidade entre os estudantes alvos, estratégia para tentar facilitar a distribuição do filme. Diante daquele cenário delinearam-se os aspectos criativos da película: Primeiro, o posicionamento: conduta dramática intimidadora, capaz de impressionar, marcar eventos cirurgicamente e atingir com precisão o target. Segundo o público objeto, calouros do curso de arquitetura do UniCEUB. Terceiro, o problema que Porcus Píritus pretendia resolver: conscientização entre os alunos sobre a preservação e limpeza dos espaços. Quarto, os benefícios da obra: laboratórios de projetos mantidos e organizados. Quinto, a promessa básica: capacitar alunos com a consciência da limpeza e organização do entorno acadêmico. Sexto, a promessa secundária: organização e disciplina, reflexões para o futuro profissional de sucesso. Sétimo, e último, o conceito criativo: construção da história por meio do gênero suspense. $O$ tema do filme deveria ser algo marcante, para que fosse lembrado ao longo da formação académica dos calouros: sentir "medo" da situação de erro como um corretivo para nunca mais se esquecer do recado! Mas, corrigir com muito humor! Então, o roteiro foi inicializado com a seguinte linha da história: Uma estudante adota péssimos hábitos em sua vida por isso acaba morta, depois, em espírito arrepende-se de seus erros e monitora os espaços acadêmicos. A partir dessa ideia se desenvolveu o argumento e roteiro audiovisual: as soluções propostas diante de pesquisas qualitativas, quantitativas e bibliográficas mostraramse adequada como enfrentamento de situação problema. Obteve-se resultados positivos e de relevante sucesso. Foi atendido o anseio dos veteranos de arquitetura e mudou-se a disposição nos ateliês e laboratórios de projeto. Confirmou o planejamento audiovisual como educação transformadora. 
Palavras-chave: Poder; Arquitetura; Cinema; Educação.

\section{REFERÊNCIAS}

ADORNO, Theodor. Educación para la emancipación. Madrid: Ediciones Morata, 1998.

APPLE, Michael W. Politica Cultural e Educação. São Paulo: Cortez, 2000.

BAUMAN, Zygmunt. Arte da vida. São Paulo, Zahar, 2008.

BRECHT, Berthold. A exceção e a regra. São Paulo, 1994.

BORGES, Jorge Luís. Esse ofício do verso. São Paulo: Conpanhia das Letras, 1968.

FOULCAUT, Michel. Microfísica del poder. Madrid: La piqueta ediciones, 1980.

LANCASTER, Joseph. Mejorías en la educación. Darton e Harvey, 1803.

LAPASSADE, George. El analizador y el analista. Barcelona: Gedisa, 1977.

LEVI, Primo. Os afogados e os sobreviventes. São Paulo: Paz e Terra, 1990.

LOURAU, R. El análisis institucional. Buenos Aires: Amorrortu, 1974.

LUMET, Sidney. Fazendo Filmes. Rio de Janeiro: Rocco 1998.

RODRIGUES, Chris. O Cinema e a produção. FAPERJ/DP\&A, 2005. 


\title{
UM ESTUDO SOBRE A VIOLÊNCIA: UMA CONTRIBUIÇÃO PARA A COMUNIDADE ESCOLAR
}

\author{
Altair Stemler da Veiga ${ }^{1}$ \\ Maria Eleusa Montenegro² \\ Eliete de Pinho Araujo ${ }^{3}$
}

\section{RESUMO}

Trata-se de um trabalho voltado para o estudo, análise e plano de ação voltada ao fenômeno da violência nas escolas, sobretudo na escola pública de ensino Fundamental e Médio de Santa Maria Região Administrativa do Distrito Federal, em que foi realizada uma pesquisa. Diante da constatação da violência presente na escola, o trabalho em questão, procura propor estratégias que podem ser tomadas a fim de minimizar o problema enfrentado por educadores. No entanto, a escola não pode ignorar que os conflitos e problemas sociais existem. Consciente disto acaba percebendo que seu trabalho é insuficiente para acabar com a violência, sugere-se que, toda a sociedade se mobilize para garantir o objetivo comum das escolas que é a formação dos cidadãos. Este trabalho teve como objeto de pesquisa analisar a violência em uma escola pública de ensino fundamental e médio, na região administrativa de Santa Maria, à época com poucos anos de funcionamento, em uma região onde prevalece uma população de baixa renda. A sociedade brasileira se depara atualmente com um aumento significativo da violência, sobretudo da violência escolar, pelos diversos episódios de agressões verbais e físicas envolvendo os atores desta comunidade. Fatos esses que despertam a atenção da sociedade em geral, o que demonstra ser a violência na escola um problema social considerado um dos principais males da vivência escolar. Tal situação é responsável, em parte, pela evasão escolar, por afastamento de professores (grande número de licenças médicas), causadas por doenças psicossomáticas (stress), pela baixa no rendimento dos alunos, enfim, pelo medo e insegurança que acometem as escolas na maioria das regiões do país. O objetivo geral desse projeto foi conhecer as causas e situações de violência nas escolas, levantando medidas de solução ao problema. Para tanto, optou-se pela

\footnotetext{
${ }^{1}$ Centro Universitário de Brasília / stemler@terra.com.br

${ }^{2}$ Centro Universitário de Brasília / maria.montenegro@ceub.edu.br

${ }^{3}$ Centro Universitário de Brasília/ eliete.araujo@ceub.edu.br
} 
pesquisa qualitativa e foram realizadas entrevistas semiestruturadas objetivando identificar e conhecer o fenômeno da violência na escola e a forma que se apresenta. Os participantes da escola, dois professores, um orientador e a diretora da escola possuíam graduação e especializações; os demais entrevistados, um representante da Organização não Governamental $(\mathrm{ONG})$ e um da comunidade são graduados e o representante do Conselho Tutelar possuía ensino médio. Suas idades variaram entre 30 e 60 anos e quanto ao tempo de serviço estavam entre dois a vinte anos. As categorias selecionadas para este trabalho foram: formas de violência; causas da violência; consequências da violência; medidas de prevenção e de diminuição da violência; papel da escola diante da violência; posição dos pais, da comunidade e do Estado; preparação para lidar com a violência. A seguir são apresentados os dados analisados e discutidos, dentro de cada uma das categorias selecionadas. Quando questionados sobre as mais frequentes manifestações de violência na escola, os representantes da escola apontaram o bullying, as ameaças e as agressões verbais, como os tipos mais frequentes. Sobre os tipos mais frequentes de violência na comunidade, os representantes apontaram abandono de incapaz, dependência química, bullying, brigas entre gangues e assassinatos de jovens. Os professores já presenciaram atitudes de violência e também já foram vítimas de alguns tipos de violência, como agressões verbais e ameaças contra a sua integridade física. Ruotti, Alves e Cubas (2006) nesse sentido, afirma que os professores devem ser capazes de intervir e de evitar conflitos e tratamentos violentos. Relativamente às causas da violência os fatores apontados por todos os participantes foram a falta de investimento na educação, o ambiente familiar violento, o meio social, o alcoolismo, a impunidade nacional, a pobreza, as drogas, a desestrutura familiar, o preconceito, entre outros. Quanto às consequências da violência, citou-se a evasão escolar, a descrença nas instituições e nas pessoas, a desmotivação, a agressividade dentro e fora da escola, a sua desvalorização e, ainda dos professores, a falta de identidade, $o$ baixo rendimento, a infrequência, os vícios, de uma forma geral. Arendt (1994) lembra que um aluno indisciplinado pode causar muitos prejuízos ao contexto escolar. Todos os participantes responderam que a prevenção ocorre no cotidiano de sala de aula, e para isto, devem ser promovidas palestras e debates para conscientizar o aluno sobre a gravidade do tema, além de projetos abordando o tema para tentar manter a ordem em sala de aula, com vigilância constante. De acordo com os representantes da comunidade e ONG devem ser tomadas medidas preventivas em concordância com o ECA e desenvolvidos trabalhos em conjunto, onde todos se responsabilizem pelos fatos e incentivo ao esporte, cultura e lazer para crianças e jovens. Nas propostas de soluções, de acordo com Fante (2005), "a escola deve ensinar os alunos a lidarem com suas emoções para que não se envolvam em comportamentos violentos, transformando-os em agentes disseminadores de uma cultura de paz que se estenda aos seus demais contextos de vida". Para o diretor, a escola possui uma postura bem rígida quanto à violência, e está em consonância com 
a Secretaria de Educação, que procura inserir a família no processo de assumir, também, as suas responsabilidades. Com relação à questão de onde partia a violência, se era entre aluno-aluno, aluno- professor ou mesmo professor-professor, a resposta foi taxativa de que era entre os alunos. De acordo com o diretor da escola, os pais participam minimamente na vida escolar dos filhos e somente comparecem à escola quando são chamados pela direção. Nesta realidade, a ausência da família influencia amplamente no contexto de violência. Sendo a família o modelo inicial de socialização, ela deve construir um modelo positivo para a criança, pois a relação de afeto com as figuras paternas e maternas são os registros iniciais de experiências emocionais, que repercutem na formação da personalidade do indivíduo. Para os participantes, somente o Estado não é suficiente no combate à violência, mas também a família, as escolas, a igreja, a comunidade e a sociedade em geral. $\mathrm{O}$ engajamento de todos esses seguimentos deve ser total. Constatou-se em alguns depoimentos o medo dos professores de lidar com determinadas situações, quando acontecem nos arredores da escola, em especial, os problemas com o tráfico de entorpecentes. Os professores, realmente, não foram preparados para lidar com esse fenômeno e acabam por utilizar suas experiências para contornar as situações de violência. Esta pesquisa demonstrou que as escolas estão despreparadas para lidar com esta problemática e que os professores não possuem uma formação adequada para lidar com o tema. De um modo geral, cita-se o desenvolvimento de projetos, como se a violência possa ser trabalhada, pontualmente, e não durante todo o tempo. Observam-se tipos de violência praticados tanto na escola como nos seus arredores e um deles é o bullying, que surgiu nas últimas décadas para classificar um tipo de violência que tem aparecido, principalmente, nas escolas, como reflexo uma sociedade que está na contramão. Embora não seja um fenômeno novo, tem sido estudado recentemente, em função da proporção atual, onde o agressor é sempre alguém em situação de vantagem em relação ao agredido. De acordo com a pesquisa, percebeu-se que as pessoas da comunidade escolar apresentam de forma eficaz, propostas para prevenir e combater a violência, como programas de esportes, de lazer e de cultura. Profissionais preparados e dispostos a transformar o contexto escolar buscam alterar os comportamentos agressivos no ambiente escolar. Este trabalho concluiu que acabar com a violência social e estabelecer uma paz global é quase impossível, e reduzir essa violência não é uma missão tão fácil. Porém, se houver conscientização, planejamento, comprometimento, cooperação e investimento de toda a sociedade e do Estado, acredita-se que seja possível e viável o seu combate e diminuição. Vale ressaltar que a diminuição da violência na educação e a melhoria do seu convívio dependem de vários níveis de atuação, desde os órgãos gestores centrais que elaboram políticas e programas até as escolas, que precisam estar mobilizadas para acolher essas iniciativas, com a ajuda da comunidade. Esta pesquisa pretende contribuir com outras instituições escolares para a diminuição do 
problema da violência escolar, em prol de uma sociedade melhor e de uma infância e adolescência mais viáveis.

Palavras-chave: Violência na escola; Subsídios para Plano de Ação; Comunidade escolar.

\section{REFERÊNCIAS}

ARENDT, H. Sobre a violência. Rio de Janeiro: Relume-Dumará, 1994.

RUOTTI, Caren; ALVES, Renato; CUBAS, Viviane de Oliveira. Violência na escola: um guia para pais e professores. São Paulo: Imprensa Oficial do Estado de São Paulo, 2006.

FANTE, Cleo. Fenômeno bullying: como prevenir a violência nas escolas e educar para a paz. 2. ed. São Paulo: Verus, 2005. 